\title{
Regulation and role of Notch signaling in epithelial progenitor cell differentiation and proliferation in the normal and the fibrotic lung
}

\author{
Inauguraldissertation \\ zur Erlangung des Grades eines Doktors der Humanbiologie \\ des Fachbereichs Medizin \\ der Justus-Liebig-Universität Gießen
}

\author{
vorgelegt von \\ Piskulak Katarzyna, Teresa \\ aus \\ Kielce, Polen
}

Gießen 2012 
Aus dem Zentrum für Innere Medizin

Der Universitätsklinikum Gießen und Marburg GmbH

Standort Gießen

Leiter : Prof.Dr.W.Seeger

Gutachter: Prof. Dr.A.Günther

Gutachter: Prof.Dr.S. Gattenlöhner

Tag der Disputation: 19.02 .2013 


\section{Table of contents}

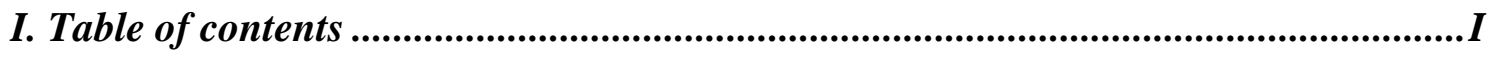

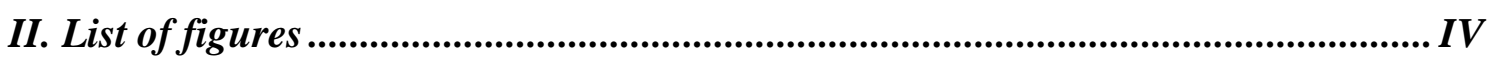

III. List of tables.................................................................................................................. VI

IV. List of abbreviations .............................................................................................

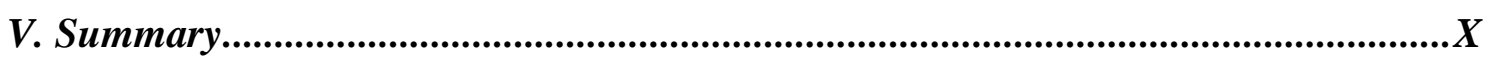

VI. Zusammenfassung......................................................................................

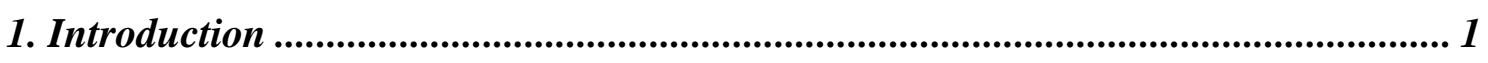

1.1. Idiopathic pulmonary fibrosis ............................................................................ 1

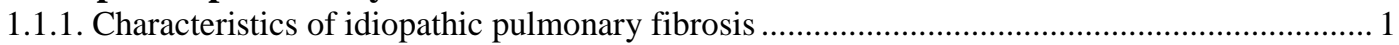

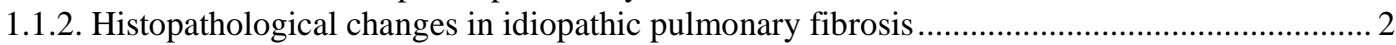

1.1.3. Pathogenesis of idiopathic pulmonary fibrosis ....................................................................... 3

1.1.4. Alveolar epithelial cells as one of the key effector cells in idiopathic pulmonary fibrosis....... 6

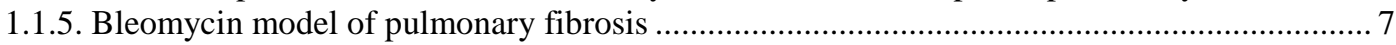

1.2. The Notch signaling pathway.................................................................................................. 8

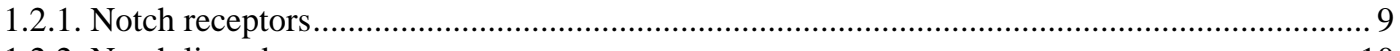

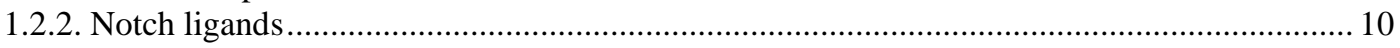

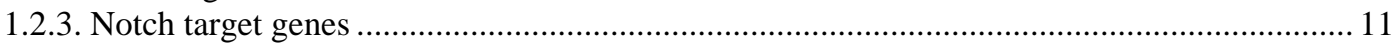

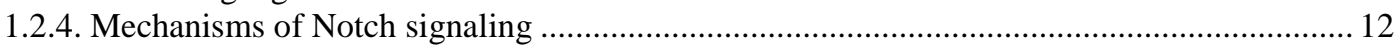

1.3. The Notch signaling pathway in lung diseases ........................................................... 13

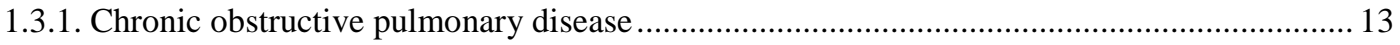

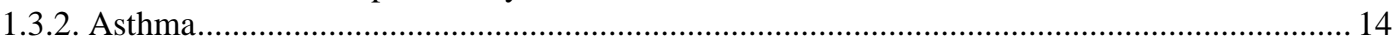

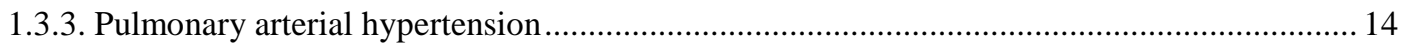

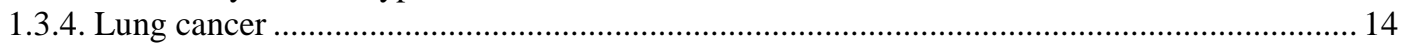

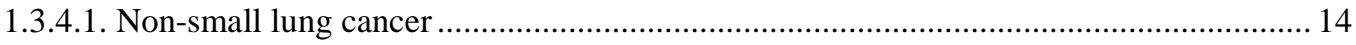

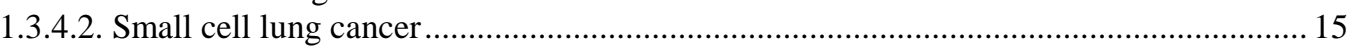

1.4. The Notch signaling pathway in organ fibrosis................................................... 15

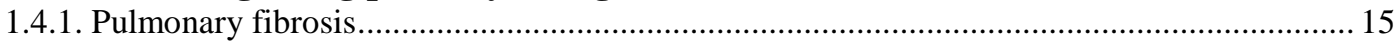

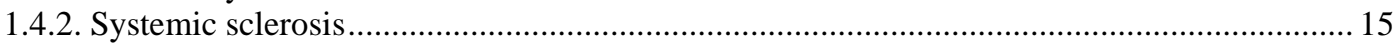

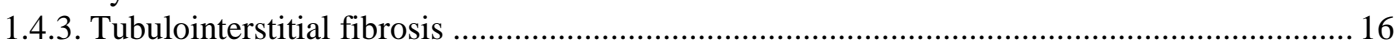

1.5. The Notch signaling pathway in lung development ........................................................ 16

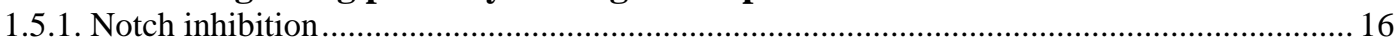

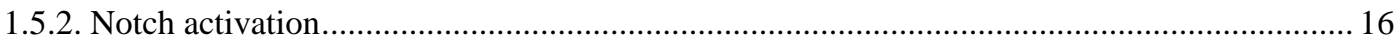

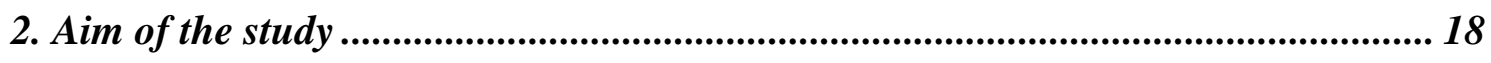

3. Materials and methods.................................................................................................. 19

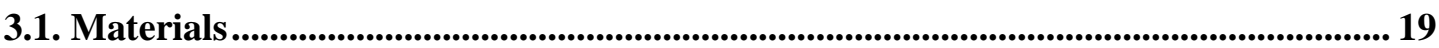

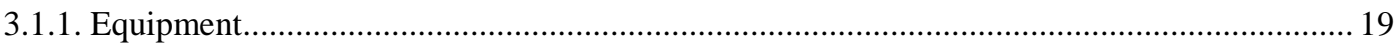

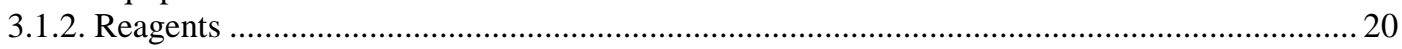

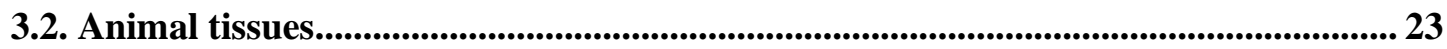

3.3. Human tissues ....................................................................................................................................... 23

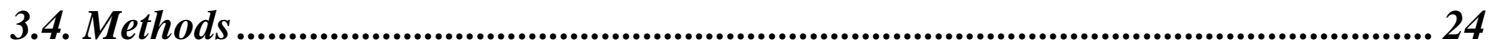

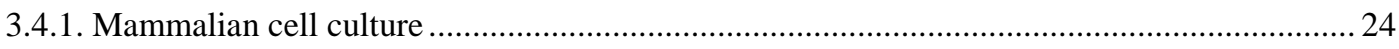

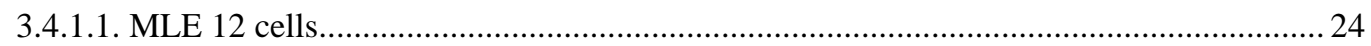

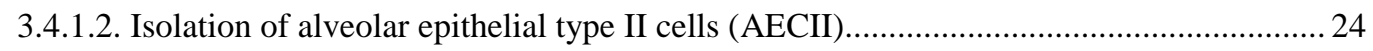

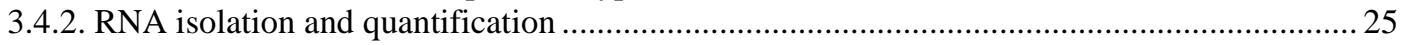

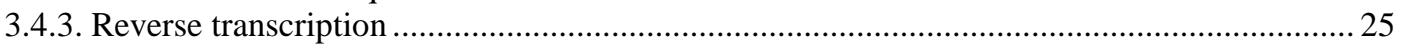




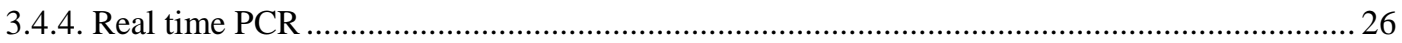

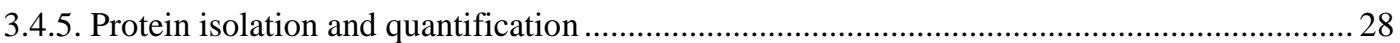

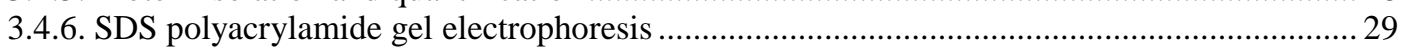

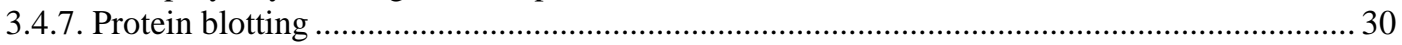

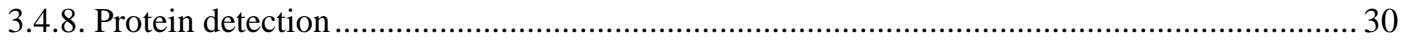

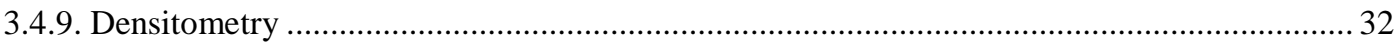

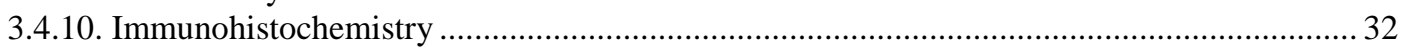

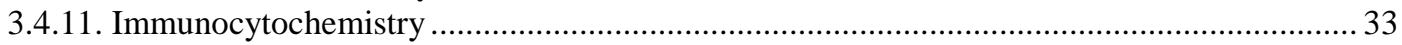

3.4.12. Cloning of the mouse intracellular Notch1 receptor ................................................... 34

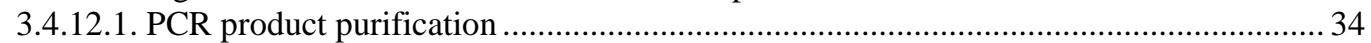

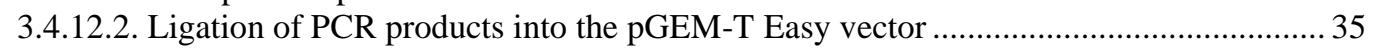

3.4.12.3. Transformation and amplification of plasmid .................................................... 35

3.4.12.4. Subcloning into the mammalian expression vector............................................. 35

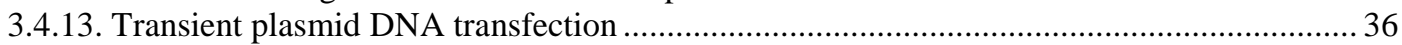

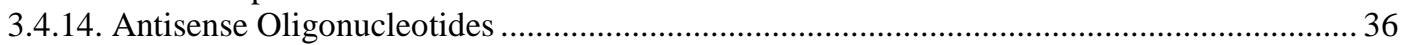

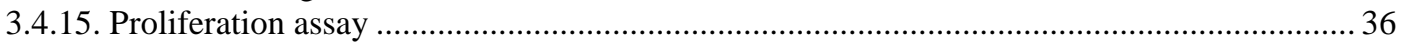

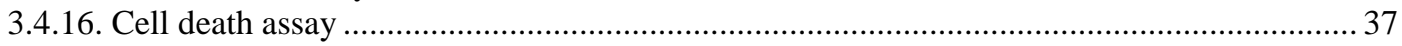

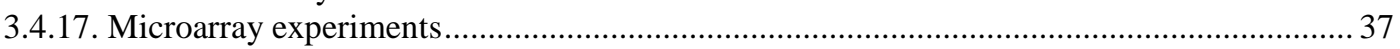

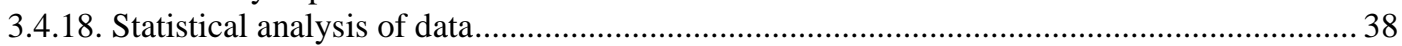

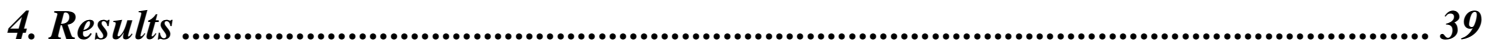

4.1. Identification of differently regulated pathways in septae from IPF vs. healthy

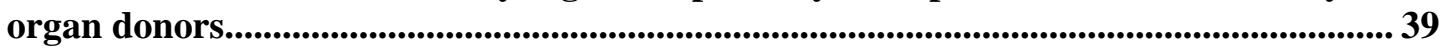

4.2. Analysis of the Notch signaling pathway in lungs of patients with idiopathic pulmonary fibrosis ....................................................................................................................40 40

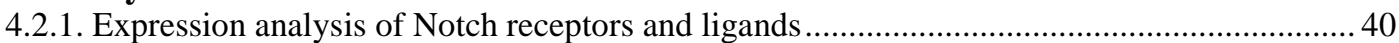

4.2.2. Localization of NICD1 and DLL1 in the lungs of patients with idiopathic pulmonary fibrosis

4.2.3. Expression analysis of the Notch target gene HES1 .................................................... 45

4.3. Analysis of the Notch signaling pathway elements in an experimental model of pulmonary fibrosis .................................................................................................................... 46

4.3.1. Expression of Notch signaling pathway elements in bleomycin- induced pulmonary fibrosis

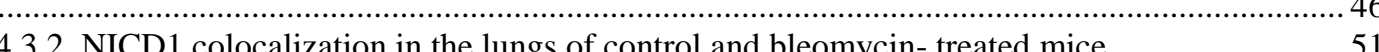

4.4. Influence of Notch signaling on epithelial proliferation ..............................................552

4.4.1. Influence of NICD1 expression on proliferation of MLE 12 cells ..................................5 52

4.4.2. Influence of Notch signaling inhibition on epithelial proliferation and survival ....................54

4.4.2.1. Inhibition of Notch signaling in the mouse epithelial cell line (MLE 12) .........55

4.4.2.2. Influence of Notch signaling on proliferation of primary mouse AECII ......................58

4.4.3. Expression of NICD1 and the proliferation marker in lung tissue of IPF patients .................59

4.5. Influence of Notch signaling on apoptosis in vitro ......................................................6 60

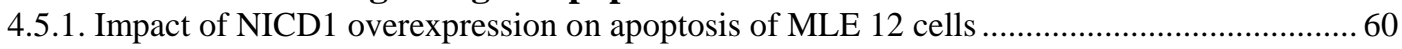

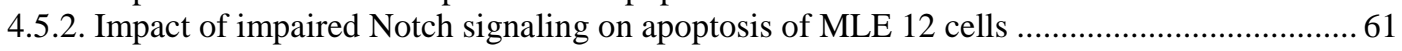

4.6. Downstream signaling of Notch1 in alveolar epithelial cells......................................... 62

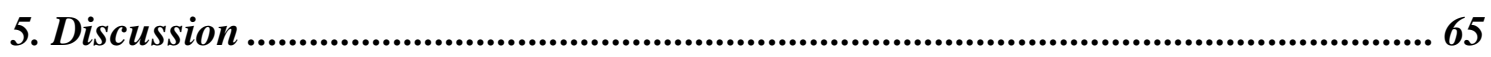

5.1. Reactivation of developmental pathways in lung fibrosis ........................................ 65

5.2. Reactivation of the Notch signaling pathway in lung fibrosis and other diseases.... 68

5.3 Alveolar epithelium as a target cell type for Notch signaling ......................................69

5.4. Impact of Notch signaling on proliferation and possible differentiation.................... 71

5.5. Downstream signaling of Notch responsible for enhanced proliferation.................... 74

5.6. Impact of Notch activation on alveolar epithelium cell death ..................................... 75

5.7. Conclusions and future directions ................................................................................ 76 
Table of contents

6. References ........................................................................................ 79

8. Declaration ....................................................................................... 93

9. Acknowledgements............................................................................... 94 


\section{List of figures}

Figure 1.1. Histopathological changes observed in IPF.

Figure 1.2. UIP pattern demonstrates the characteristic variegated appearance.

Figure 1.3. Hypothetical scheme of the main pathogenic events in IPF/UIP.

Figure 1.4. Hypothesis for the pathogenesis of IPF.

Figure 1.5. Characteristic pathology seen in the bleomycin model.

Figure 1.6. Structure of Notch and its ligands.

Figure 1.7. The switch model for Notch target gene regulation by RBP-Jк.

Figure 1.8. Canonical Notch signaling pathway.

Figure 1.9. Model of Notch action in mouse lung development.

Figure 4.1. Pathway analyses performed on data obtained from microarray experiments on microdissected septae and lung homogenates from IPF $v s$. healthy organ donors.

Figure 4.2. Expression analysis of Notch receptors and ligands in lung homogenates of organ donors and IPF patients.

Figure 4.3. Expression of NICD1 and DLL1 in AECII in lungs from organ donors and IPF patients.

Figure 4.4. Absence of NICD1 and DLL1 in mesenchymal cells in lungs from organ donors and IPF patients.

Figure 4.5. Expression and colocalization of NICD1 and DLL1 in the same population of AECII in lung tissue of IPF patients.

Figure 4.6. Expression analysis of Hes1 in lung homogenates of organ donors and IPF patients.

Figure 4.7. Expression of Hes1 in AECII in lungs from organ donors and IPF patients.

Figure 4.8. Expression analysis of Notch receptors in lung homogenates of control and bleomycin-challenged mice. 
Figure 4.9. Expression analysis of Notch ligands in lung homogenates of control and bleomycin-challenged mice.

Figure 4.10. Expression and colocalization of the NICD1 receptor in AECII in lungs of control and bleomycin-treated mice.

Figure 4.11. Overexpression of the NICD1 receptor in MLE 12 cells.

Figure 4.12. Cell proliferation in Notch-expressing MLE 12 cells.

Figure 4.13. Analysis of siRNA-mediated knockdown of POFUT1.

Figure 4.14. Analysis of chemical NICD1 inhibition in MLE 12 cells.

Figure 4.15. Proliferation of MLE 12 cells upon inhibition of Notch signaling.

Figure 4.16. Purity of primary AECII.

Figure 4.17. Proliferation of AECII cells isolated from saline and bleomycin (day 14) treated mice.

Figure 4.18. Expression and colocalization of NICD1 and Ki67 in AECII in lung tissue of IPF patients.

Figure 4.19. Extent of apoptosis of MLE 12 cells, in response to NICD1 overexpressing and staurosporine treatment.

Figure 4.20. Influence of Notch inhibition on cell death of MLE 12 cells.

Figure 4.21. Regulation of MAPK pathway elements after NICD1 overexpression in MLE 12.

Figure 5.1. Differential regulation of Notch pathway activation may have a diverse impact on AECII proliferation and transdifferentiation into AECI. 


\section{List of tables}

Table 1. List of primers used for Real time PCR.

Table 2. List of primary antibodies used in Western Blot.

Table 3. List of primary antibodies used in Immunohistochemistry.

Table 4. List of primary antibodies used in Immunocytochemistry.

Table 5. Pathway analysis performed with Gene Set Enrichment Analysis. 


\section{List of abbreviations}

\begin{tabular}{|c|c|}
\hline AECI & Alveolar epithelial cells type I \\
\hline AECII & Alveolar epithelial cells type II \\
\hline APS & Ammonium Persulphate \\
\hline BASCs & Bronchoalveolar stem cells \\
\hline CADASIL & $\begin{array}{l}\text { Cerebral autosomal dominant arteriopathy with subcortical infarcts } \\
\text { and leukoencephalopathy }\end{array}$ \\
\hline COPD & Chronic obstructive pulmonary disease \\
\hline DAPI & 4',6-diamidyno-2-fenyloindol \\
\hline DAPT & $\begin{array}{l}\mathrm{N} \text {-[N-(3,5-Difluorophenacetyl)-L-alanyl]-S-phenylglycine t-butyl } \\
\text { ester }\end{array}$ \\
\hline DHODH & Dihydroorotate dehydrogenase \\
\hline DMSO & Dimethyl sulfoxide \\
\hline DPLD & Diffuse parenchymal lung diseases \\
\hline ECM & Extracellular matrix \\
\hline EDTA & Ethylenediamine-tetraacetic acid \\
\hline EGF & Epidermal growth factor \\
\hline ER & Endoplasmic reticulum \\
\hline FA & Fluorouracil \\
\hline FCS & Fetal calf serum \\
\hline FGF & Fibroblast growth factor \\
\hline HDACs & Histone deacetylases \\
\hline HEPES & 2-(-4-2-hydroxyethyl)-piperazinyl-1-ethansulfonate \\
\hline HRCT & High-resolution computed tomography \\
\hline IHC & Immunohistochemistry \\
\hline IIP & Idiopathic interstitial pneumonia \\
\hline
\end{tabular}


ILD Interstitial lung diseases

IPF Idiopathic pulmonary fibrosis

LDH Lactate dehydragenase

Lfng Lunatic Fringe

MAPK Mitogen-activated protein kinase

MLE 12 cells Mouse lung epithelial cells line

mTOR Mammalian target of rapamycin

NRK Normal rat kidney tubule epithelium

NSCLC Non small cell lung carcinomas

PAH Pulmonary arterial hypertension

PCNA Proliferating cell nuclear antigen

PMSF Phenylmethylsulfonyl fluoride

Pofut1 Protein O-fucosyltransferase 1

RAM RBPjk Associate Molecule

SCLS Small cell lung cancer

SDS Sodium dodecyl sulfate

SDS-PAGE SDS polyacrylamid gel electrophoresis

SHH Sonic hedgehog

SSc Systemic sclerosis

SFTPA Surfactant protein A

SFTPC Surfactant protein C

TACE TNF-a-converting enzyme

TAD Transactivation domain

TEC Tubular epithelial cells

TEMED N,N,N',N'-Tetramethyl-1-,2-diaminomethane

TERC Telomerase RNA component 
TGF $\beta \quad$ Transforming growth factor- $\beta$

TIF Tubulointerstitial fibrosis

UIP Usual interstitial pneumonia

VEGF Vascular endothelial growth factor

vSMC Vascular smooth muscle cells 


\section{Summary}

It is increasingly accepted that the alveolar epithelial cell plays a major role in the pathogenesis of idiopathic pulmonary fibrosis (IPF), a dismal disease with an average survival time of $\sim 3$ years and a progressive decline in lung function and exercise capacity. In IPF, chronic injury of alveolar type II cells (AECII) seems to cause disturbed alveolar re-epithelialization (1). It appears that profoundly increased epithelial apoptosis, which occurs due to epithelial injury, causes accelerated epithelial cell proliferation and further apoptosis (2, 3 and 4).

The Notch signaling functions as a mediator of a cell-cell communication. The Notch pathway is known to be involved in proliferation, cell death, stem cell maintenance and differentiation during embryonic and adult development (5-8). In addition the Notch network has already been identified to play a role in some chronic lung diseases such as COPD or PAH $(9,10)$. Until now, the Notch signaling pathway has not been investigated in IPF. In particular, the impact of Notch activation on alveolar epithelial proliferation and apoptosis has yet not been analyzed.

The present study was undertaken to evaluate the regulation and the potential role of Notch activation in repair processes in IPF lungs. We investigated the cellular regulation of the Notch signaling pathway on mRNA, protein and immunohistochemical level (IPF vs. donor lungs; bleomycin-treated vs. control mice lungs). Proliferation and survival of an AECII and AECII-like cell line (MLE 12) was investigated after in vitro transfection with Notch1 ICD, POFUT1 siRNA and DAPT ( $\gamma$-secretase inhibitor) treatment.

Our transcriptome data proved differential regulation of the Notch signaling pathway in microdisected septae from still ,normal” appearing areas (representative of the early-stage of the disease) of IPF lungs compared to septae of healthy organ donors. On protein level, no significant changes in the expression of Notch pathway elements were observed with the exception of the intracellular domain of Notch1 receptor (NICD1), the ligand DLL1 and the downstream target Hes1, which were found to be significantly increased in IPF $v s$. donor lungs. We also observed increased protein levels of NICD1 and D1l1 in lungs of bleomycin-treated mice. Expression of these proteins was mainly restricted to AECII of fibrotic lungs. Moreover on the IHC level, expression of NICD1 and DLL1 proteins seems to be increased in AECII in IPF as compared to 
controls. Furthermore, we observed a characteristic staining pattern, where subpopulation of AECII cells expressed Notch1 in cytoplasm and neighboring AECII cell showed localization of this receptor in the nucleus. Most importantly, observations made after NICD1 overexpression or Notch pathway inhibition in the MLE 12 alveolar epithelial cell line and mouse primary AECII cells isolated from bleomycin-challenged mice indicate that Notch plays a major role in uncontrolled AECII proliferation in vitro. In addition, there was no influence of the Notch signaling pathway on epithelial apoptosis. Furthermore, genome wide mRNA microarray analysis of NICD1overexpressing MLE 12 cells revealed differential regulation of the MAPK pathway. We found that NICD1 overexpression in MLE 12 cells induced phosphorylation of Erk5. Therefore, we can speculate that Erk5 may be a downstream effector of Notch1 activation, involved in increased alveolar epithelial cell proliferation.

Our findings demonstrate for the first time a potential role of the Notch signaling pathway in the re-epithelialization process in the lung, which may indicate involvement of Notch on pathogenesis of pulmonary fibrosis. 


\section{Zusammenfassung}

Es findet zunehmend Akzeptanz, dass die alveolaren Epithelzellen eine wesentliche Rolle in der Pathogenese der idiopathischen pulmonalen Fibrose (IPF) spielen, einer prognostisch ungünstig verlaufenden Krankheit mit einer medianen Überlebenszeit von etwa 3 Jahren und einer fortschreitenden Abnahme der Lungenfunktion und Belastbarkeit. Bei der IPF scheint eine chronische Schädigung der alveolaren TypII Zellen (AECII) eine gestörte alveolare Reepithelisierung zu verursachen (1). Anscheinend bewirkt stark vermehrte Apoptose, hervorgerufen durch Schädigung des Epitheliums, beschleunigte Epithelzellvermehrung und weitere Apoptose (2, 3 und 4).

Die Notch-Signalkaskade fungiert als Vermittler der Zell-Zell-Kommunikation. Bekanntermaßen ist der Notch-Signalweg in Proliferation, Zelltod, Stammzellerhaltung und -differenzierung während der embryonalen und adulten Entwicklung involviert (5-8). Des Weiteren spielt er eine Rolle bei einigen chronischen Lungenerkrankungen, wie COPD oder PAH (9, 10). Bisher wurde die Rolle des Notch-Signalwegs im Zusammenhang mit der IPF, insbesondere der Einfluss der Notch-Aktivierung auf die Proliferation und Apoptose der alveolaren Epithelzellen, noch nicht analysiert.

In der vorliegenden Arbeit sollte die Regulation und die mögliche Rolle der Notch-Aktivierung bei Regenerationsprozessen in IPF Lungen untersucht werden. Die zelluläre Regulation des Notch-Signalwegs wurde auf mRNA- und Proteinebene sowie auf immunhistochemischer Ebene untersucht (IPF vs. Donorlungen; Lungen von Bleomycin-behandelten Mäusen und Kontrollen). Proliferation und Überleben von AECII und einer AECII ähnlichen Zelllinie (MLE 12) wurden nach in vitro Transfektion mit Notch1 ICD, POFUT1 siRNA und nach Behandlung mit einem $\gamma$-Sekretase-Inhibitor (DAPT) untersucht.

Anhand unserer Transkriptomdaten konnten wir unterschiedliche Regulation des Notch-Signalwegs in Septen (durch Mikrodissektion erhalten) normal erscheinender Bereiche von IPF Lungen (einem frühen Krankheitsstadium der IPF entsprechend) im Vergleich zu Septen gesunder Spenderlungen nachweisen. Auf Proteinebene konnten wir keine signifikanten Unterschiede in der Expression von Bestandteilen der NotchSignalkaskade feststellen, mit Ausnahme der intrazellulären Domäne des Notch1 Rezeptors (NICD1), des DLL1 Liganden und des downstream target Hes1, welche im 
Vergleich zu Donorlungen in IPF Lungen signifikant erhöht waren. Ebenso zeigten sich auf Proteinebene erhöhte Werte von NICD1 und D1l1 in Lungen von Bleomycinbehandelten Mäusen. Die Expression dieser Proteine war hauptsächlich auf AECII fibrotischer Lungen beschränkt. Im Vergleich zu Spenderlungen scheint die Expression von NICD1 und DLL1 auf immunhistochemischer Ebene in IPF-Lungen erhöht zu sein. Des Weiteren beobachteten wir ein charakteristisches Färbemuster, bei dem ein Teil der AECII Notch1 im Zytoplasma exprimierte, während bei benachbarten AECII dieser Rezeptor im Nukleus lokalisiert war.

Wesentlich sind Beobachtungen nach Überexpression von NICD1 oder Inhibition der Notch-Signalkaskade in der MLE 12 Zelllinie und in von Bleomycinbehandelten Mäusen isolierten AECII, die zeigen, dass Notch in vitro eine wichtige Rolle in der unkontrollierten Proliferation von AECII Zellen spielt. Der Notch Signalweg hatte keinen Einfluss auf die Apoptose der Epithelzellen. Weiterhin zeigte eine genomweite mRNA-Analyse mit Mikroarrays von NICD1 überexprimierenden MLE 12 Zellen differenzielle Regulation des MAPK Signalwegs. NICD1Überexpression in MLE 12 Zellen induzierte eine Erk5-Phosphorylierung. Daher können wir vermuten, dass Erk5 ein in die erhöhte Proliferation der alveolaren Epithelzellen involvierter Downstream-Effektor der Notch1 Aktivierung ist.

Unsere Ergebnisse zeigen erstmals eine mögliche Rolle des Notch-Signalwegs in Reepithelisierungsprozessen der Lunge. Dies könnte auf eine Beteiligung von Notch an der Pathogenese der pulmonalen Fibrose hindeuten. 


\section{Introduction}

\subsection{Idiopathic pulmonary fibrosis}

\subsubsection{Characteristics of idiopathic pulmonary fibrosis}

Idiopathic pulmonary fibrosis (IPF) is a chronic, progressive, fibrotic lung disease (11). It belongs to a family of lung disorders known as interstitial lung diseases (ILD) or, more precisely, diffuse parenchymal lung diseases (DPLD). IPF belongs to the group of idiopathic interstitial pneumonia (IIP) and is related to the pathologic pattern known as usual interstitial pneumonia (UIP). Until now, the etiology of IIP has not been discovered (12). IPF affects slightly more men than women and increases with age. Most commonly the disease develops after the fifth decade of life, affecting patients over 60 years of age (13). So far it has been demonstrated that IPF does not occur in any particular ethnic group or social environment. It is known that IPF affects around 5 million people worldwide and over the last decade, the number of IPF diagnosed patients has been on the rise (14).

IPF patients experience breathlessness which is commonly initially attributed to aging, cardiac disease, or emphysema, resulting in a typical delay in diagnosis. Patients can also experience a dry cough (15). In around $90 \%$ of patients with IPF gastroesophageal acid reflux can be present (16). Another visible symptom of IPF can also be finger clubbing found in almost every IPF patient. In the end-stage the disease pulmonary hypertension may develop with classic signs of right heart failure (15). Initial development of symptoms is usually slow, but may become more rapid with time. The prognosis of IPF patients is 3-5 years after diagnosis (11).

The diagnostic standard of IPF consists of clinical, radiological and pathological assessments. According to procedure, the diagnosis of IPF can be considered definitive only if other known causes of interstitial lung disease (e.g. connective tissue disease, environmental exposure) have been ruled out, a high-resolution computed tomography (HRCT) has forwarded a definite UIP pattern consistent with the diagnosis and/or a surgical lung biopsy forwarded a histological pattern consistent with UIP (especially if HRCT is not prototypic) (1).

Although the cause of IPF remains unknown, major progress has been made in cellular and molecular biology on this subject. Nevertheless, although the course of the 
disease is variable, the ultimate fate is respiratory failure and death (11). With the exception of pirfenidone no effective treatment exists for IPF and the only option for affected patients is lung transplantation $(1,17)$.

\subsubsection{Histopathological changes in idiopathic pulmonary fibrosis}

The histopathological lesion associated with IPF is known as usual interstitial pneumonia (UIP) (1). It was observed that a UIP pattern is not exclusive to IPF. It is also found in other diseases such as scleroderma and occupational lung diseases such as asbestosis (18). The UIP pattern is characterized by spatial heterogenity with still normal appearing lung areas directly adjacent to areas of fibrosis (Figure 1.1.A). Alveolar septal thickening, modest interstitial inflammation, and honeycomb changes (Figure 1.1. and Figure 1.2.) are also typical signs of a UIP pattern (13). Additionally, emphysema or respiratory bronchiolitis can been seen when the patient is a former or active smoker (1). The inflammatory process is typically mild and consists primarily of lymphocytes and plasma cells, but neutrophils and eosinophils may also be present (19).
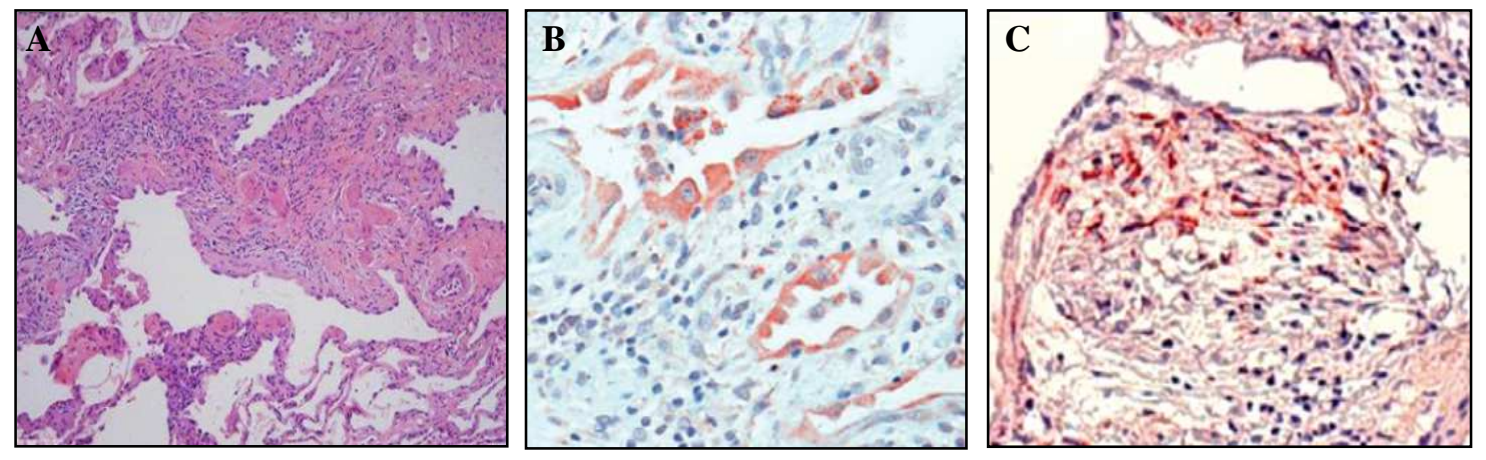

Figure 1.1. Histopathological changes observed in IPF.

A. Low-magnification photomicrograph of UIP showing the characteristic heterogeneous involvement of the parenchyma. Zones of interstitial fibrosis are seen alternating with areas of normal lung. B. Highermagnification demonstrates hyperplastic alveolar epithelium. C. Higher-magnification shows fibroblast foci (modified from 21 and 22).

At the border between fibrotic and normal lung are regions with accumulation of fibroblasts/myofibroblasts, termed fibroblastic foci (Figure 1.1.C. and Figure 1.2.) (19). It was observed that IPF patients with higher numbers of fibroblastic foci in lung biopsies had a poorer prognosis (20). An injured alveolar epithelium with hyperplastic type II pneumocytes is also one of the characteristic elements seen in areas of active fibrosis (Figure 1.1.B) (21). Further UIP features are microscopic honeycomb changes 
(Figure 1.2.). They are characterized by enlarged, cystic airspaces covered by hyper plastic type II pneumocytes as a bronchiolized epithelium (1).

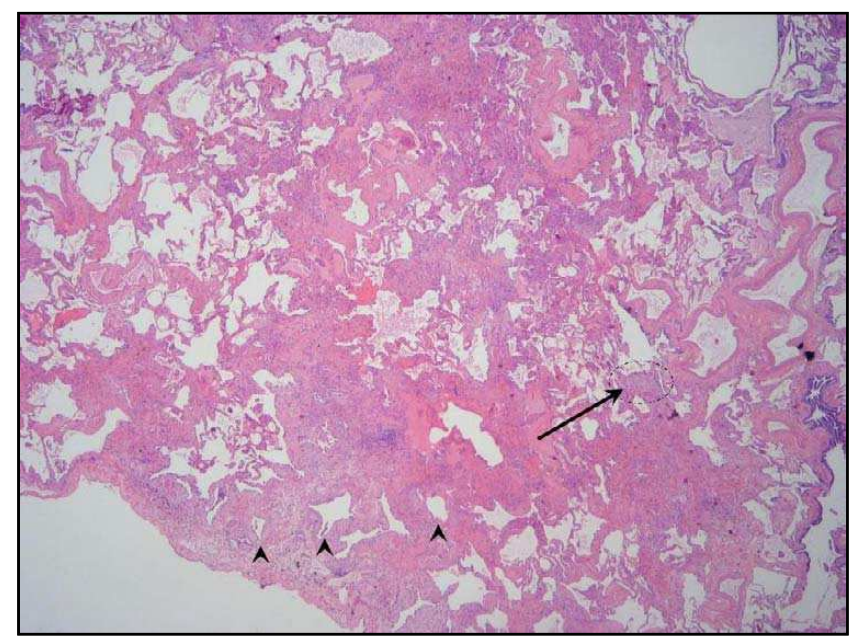

Figure 1.2. UIP pattern demonstrates the characteristic variegated appearance.

Low-magnification photomicrograph showing the honeycomb change (arrowheads) present in the area of dense fibrosis next to the pleural surface. A fibroblast focus (arrow) is seen at the leading edge of advancing fibrosis (19).

\subsubsection{Pathogenesis of idiopathic pulmonary fibrosis}

The pathogenetic mechanisms of idiopathic pulmonary fibrosis are incompletely understood. The present paradigm proposes that one of the reasons for development of IPF may be sequential alveolar injury (e.g. ER stress (2), DNA damage (3)) which afterwards leads to the epithelial cells damage. Under normal conditions, the repair process is followed by a wound-healing response, where the integrity of the epithelial barrier is initiated to restore, followed by a burst of pro-inflammatory and fibroproliferative mediators. In IPF, the wound-healing process seems to be disturbed (1). The normal wound-healing process involves re-epithelialization of the compromised area through epithelial and fibroblast cell proliferation, migration and differentiation. Fibroblast cells differentiate into myofibroblasts and extracellular matrix (ECM) deposition occurs. Furthermore, in normal wound healing, myofibroblasts undergo apoptosis and ECM is at least partially removed. It allows epithelial cells to migrate and re-epithelializate to complete tissue repair. In IPF, the above mentioned process does not occur and myofibroblast foci are formed in the injured areas, ECM continues to accumulate, the apoptotic process is impaired and proper re-epithelialization can not take place (Figure 1.3.) $(23,24)$. There are a few factors that may modify wound 
healing and the level of parenchymal fibrosis (Figure 1.4.). One of them can be the type of inflammatory response. IPF is thought to closely resemble a Th2-type immune response (eosinophils, mast cells and Th2 cytokines interleukin-4 and interleukin-13) $(19,25)$. Up to $15 \%$ of IPF cases have a familial background and are due to mutations which - in part - have already been disclosed (e.g. SFTPA, SFTPC, TERC) (26). These are the main pathogenic mechanisms that underlay IPF (Figure 1.4.). As a result of these abnormalities, gas exchange is impaired and a progressive worsening of pulmonary function and prognosis occur (1). 


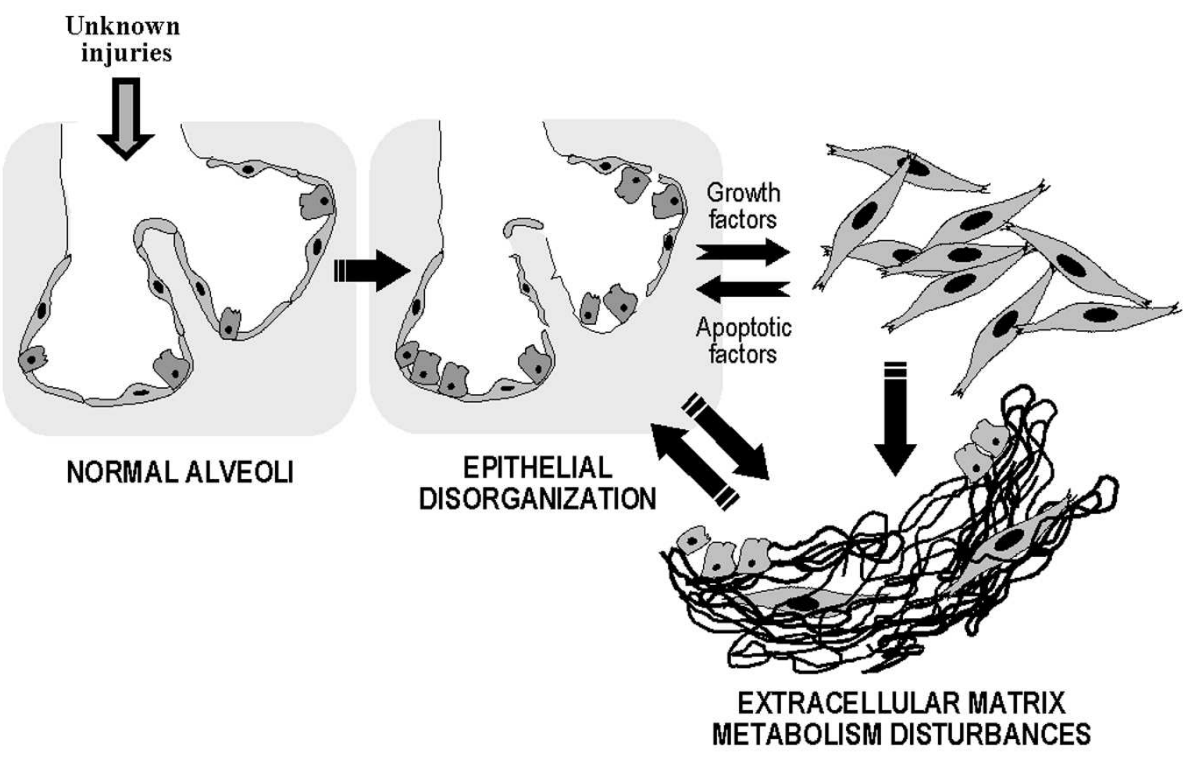

Figure 1.3. Hypothetical scheme of the main pathogenic events in IPF/UIP.

Briefly, uncharacterized unknown insults provoke multiple epithelial injuries. In this microenvironment, epithelial cells are abnormally activated and produce diverse growth factors and chemokines inducing fibroblast migration and proliferation and changes in cell phenotype. Finally, fibroblasts/myofibroblasts secrete excessive amounts of extracellular matrix components and afterwards matrix degradation does not occur. As a result aberrant remodelling of the lung parenchyma occurs (24).

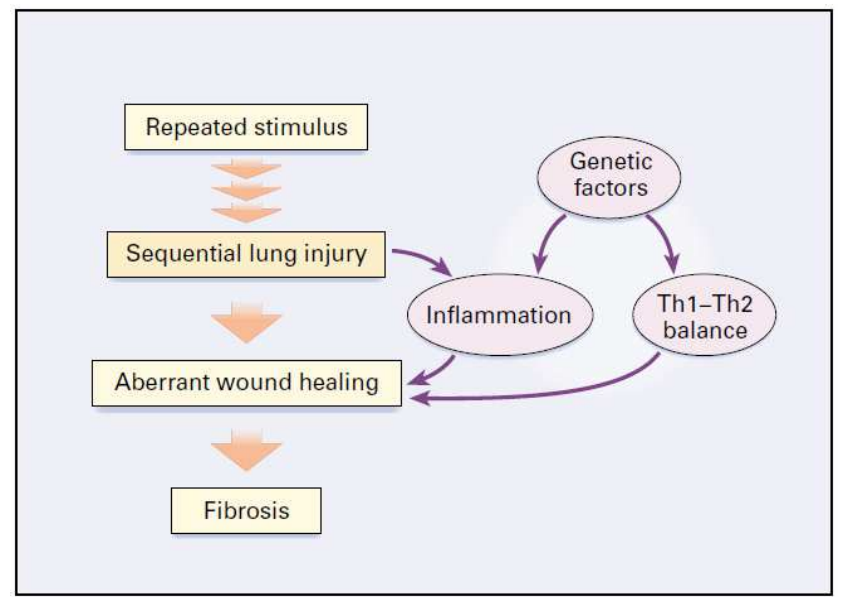

Figure 1.4. Hypothesis for the pathogenesis of IPF (modified from 23). 


\subsubsection{Alveolar epithelial cells as one of the key effector cells in idiopathic pulmonary fibrosis}

In adult lungs, type 1 and type 2 alveolar cells constitute the distal lung epithelium. Type I cells cover around $90 \%$ of the alveolar surface of the peripheral lung. Those cells interface with pulmonary capillaries, provide an intact surface permeable to gases. Type 1 cells are also highly susceptible to injury. Type 2 cells (AECII), appear as large squamous cells, which can be found in the corners of alveoli and are found near to mesenchymal cells. They synthesize and secrete pulmonary surfactant, are more resistant to injury and serve as progenitor cells for type 1 alveolar cell (24, 27 and 28). Type 2 cells take part in the sodium transport from apical to basolateral cell surfaces to minimize alveolar fluid and participate in the effector phase of the immune response, producing molecules involved in the innate host defense $(29,30)$.

IPF lungs demonstrate major changes in the alveolar epithelium. Hyperplastic type 2 pneumocytes with abundant cytoplasm, large hyperchromatic nuclei and prominent nucleoli form the majority of the epithelium (Figure 1.1.B). One may also observe large and elongated epithelial cells (fibroblast-like) and flattened and attenuated epithelial cells overlying the fibroblastic foci (1, 21, 22 and 29).

Following injury, appropriate repair of the alveolar epithelium is required to prevent excess of mesenchymal activation (Figure 1.4.). Prior to provisional matrix remodeling and removing, epithelial cells migrate above basal layers to restore the damaged area of the lung (11). As was shown previously, alveolar re-epithelialization appears severely disturbed in IPF. The reasons of the abnormal reactions of the alveolar epithelial cells (AECs) are unknown, but some of them may be the answer to the initial insult, whereas others may be the result of accelerated epithelial cell proliferation/migration which occurs after epithelial injury. Major proof of this hypothesis is a high rate of proliferating cell nuclear antigen (PCNA) observed in the hyperplastic epithelium of the honeycomb lesions. This can be a sign of accelerated epithelial cell proliferation which occurs in these lesions (4). In addition, recent data shows that the apoptosis process may also take part in the absence of proper reepithelialization. Labeling of fragmented DNA and activated caspase 3 in AECII cells which are located in areas of dense fibrosis was found in lung biopsies obtained from 
IPF patients $(2,3)$. The apoptotic alveolar epithelial cells are detected mostly in areas next to fibroblasts foci (31).

\subsubsection{Bleomycin model of pulmonary fibrosis}

Animal models play a significant role in the investigation of chronic pulmonary diseases. Different models of pulmonary fibrosis in mice are available but none of them mimic all features of human IPF. Among these mouse models are radiation, silica or asbestos induced, gene transfer of fibrogenic cytokines, various transgenic mice lines and, still considered as the gold standard, the bleomycin model of lung fibrosis (32).

Bleomycin is a chemotherapeutic antibiotic, produced by Streptomyces verticillus bacterium (33). It is used in animal models of IPF partially because lung fibrosis is one of the major adverse drug effects of bleomycin in human cancer therapy. Bleomycin causes single- and double-strand DNA breaks, interrupts the cell cycle and leads to epithelial apoptosis (34). Bleomycin causes a primary inflammatory response (pro-inflammatory cytokines: interleukin-1, tumor necrosis factor- $\alpha$, interleukin-6, interferon- $\gamma$ ) and fibrotic reactions (transforming growth factor- $\beta 1$, fibronectin, procollagen-1) within a short period of time (peak around day 14; Figure 1.5.) $(36,37)$. The switch between inflammation and the fibrosis phase is around day 9 after bleomycin treatment (35).

However, a major disadvantage of this model is that fibrosis does not develop in all animals and the disease may be self-limiting. The advantages of the bleomycin model are that it is well characterized, has clinical relevance; many delivery routes are possible for the induction of fibrosis and the time frame for expansion of fibrosis is only $14-28$ days (36). 

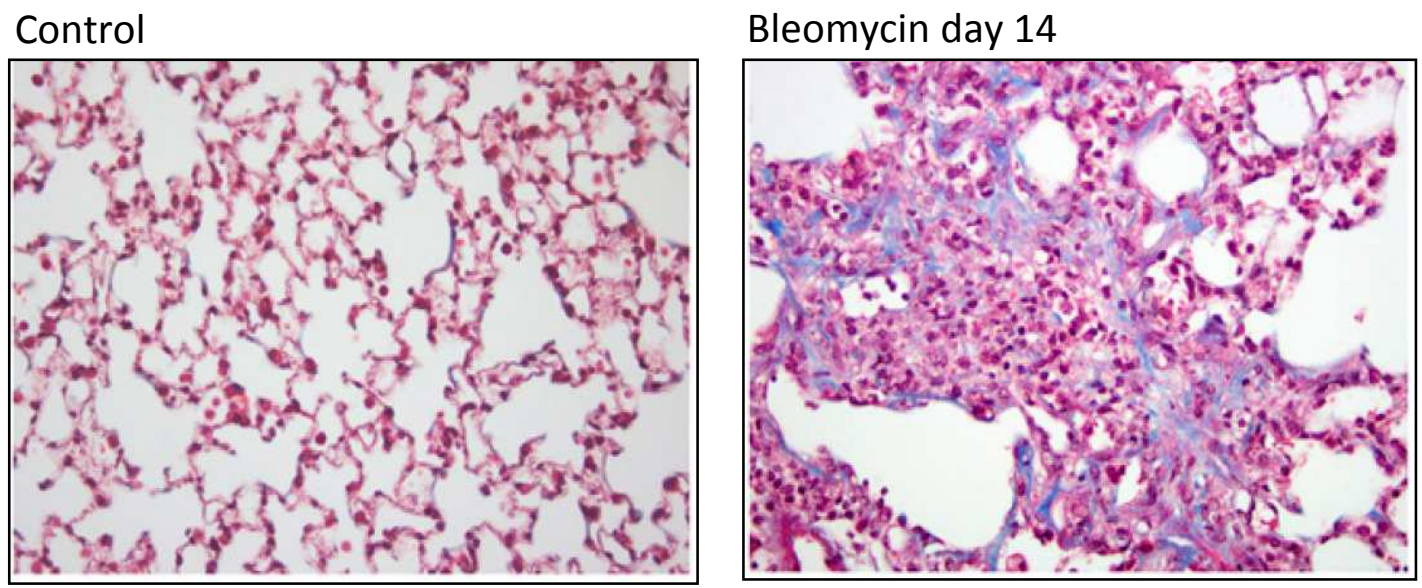

Figure 1.5. Characteristic pathology seen in bleomycin model.

Trichrome staining of a lung section from a control C57B1/6 mouse and mouse sacrificed 14 days after belomycin treatment. The blue staining represents collagen deposition (modified from 37).

\subsection{The Notch signaling pathway}

The Notch signaling pathway functions as a mediator of cell-cell communication. Notch signaling promotes or represses proliferation, cell death, stem cell maintenance and differentiation during embryonic and adult development (5, 6, 7 and 8). Because of the importance of Notch in numerous processes in a wide range of tissues, gain or loss of Notch signaling elements have been related to several human disorders as developmental syndromes (e.g. Alagille, Familial Aortic Valve Disease) (38, 39), adult onset diseases (e.g. CADASIL) (40) and cancers $(41,42)$.

A characteristic feature of Notch signaling is that functionality does not dependent on secondary messengers. Levels of activity are in the most part dependent on the nuclear concentration of NICD which, in turn, is dependent on enzymatic cleavage of the receptor upon binding of the ligand. Although NICD levels are extremely low, it has an extremely strong impact on most tissues. The preferable method to monitor NICD levels is immunodetection with antibodies raised against the epitope generated by the S3/S4 cleavage (43). Additionally, Notch signaling activity is modulated by glycosylation, differential intracellular trafficking, and ubiquitindependent degradation $(44,45)$. 


\subsubsection{Notch receptors}

The Notch receptor acts as a transmembrane receptor as well as a transcription factor. The Notch cascade is composed of notch receptors, notch ligands and intracellular proteins converting the notch signal to the cell's nucleus. In mammalian cells, there are four different notch receptors (Notch1, Notch2, Notch3, and Notch4) (44).

Notch receptors are modified in the endoplasmic reticulum (ER) and the Golgi apparatus during the secretion to the membrane. Notch is translated inside ER and then glycosylated by an O-fucosyltransferase (O-Fut1) and an O-glucosyltransferase. Next, the receptor is translocated into the Golgi apparatus, where it is cleaved by a Furin protease at the S1 site and further modified by the $\mathrm{N}$-acetylglucosaminyltransferase. At the cell surface, Notch is present as a heterodimer, consisting of the extracellular region of up to 36 epidermal growth factor (EGF)-like repeats (involved in ligand interaction) and three juxtamembrane repeats known as Lin-12-Notch (LNR). Those repeats linked non-covalently by a heterodimerization region to the rest of the molecule $(44,46)$. Intracellular part of Notch receptors contain the region called RAM (RBPjk Associate Molecule), additionally seven ankyrin repeats flanked by nuclear localization signals, a PEST domain and a transactivation domain (TAD) (Figure 1.6.A.) $(47,48)$. 
A

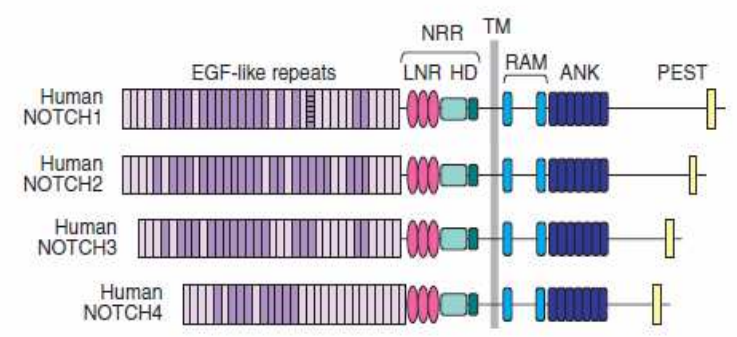

B

DSL ligands

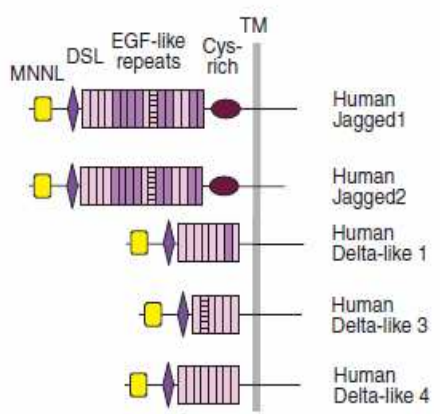

Figure 1.6. Structure of Notch and its ligands.

A. Notch receptors. Notch is composed by up to 36 EGF-like repeats. In close proximity to a cysteine-rich region are heterodimerization domains. A region called RAM (RBPjk Associate Molecule) followed by repeated structural motifs named Ankyrin repeats (mediate the interaction between Notch and RPBJ $)$, a transactivation domain (TAD) and a PEST domain. The PEST domain is involved in the degradation of Notch. B. Notch ligands. The N-terminal region of the ligands contains a conserved $\sim 100$ residue MNNL (module at the N-terminus of Notch ligands) domain. A cysteine-rich module called a DSL domain near the N-terminus, followed by a series of iterated EGF-like repeats. Serrate and Jagged ligands also contain a cysteine-rich between the EGF-like repeats and the transmembrane domain, whereas the Delta class of ligands does not (modified from 47).

\subsubsection{Notch ligands}

There are 5 canonical Notch ligands: Jagged1, Jagged2, DLL1, DLL3 and DLL4 (Figure 1.6.B). Like receptor molecules, the ligands are also transmembrane proteins (49). The ligand region of most significance for Notch signaling interactions is an extracellular cysteine rich region called DSL present in Delta and Jagged homologues. DSL mediates the interaction with Notch EGF-like repeats (47, 50 and 51).

The structural difference among the Delta and Jagged ligands is that the Jagged1 and Jagged 2 contain a greater number of EGF repeats in the extracellular region and also insertions within them. Near to the membrane region, the Jagged molecules contain a cysteine-rich region that is lacking in the Delta ligands (Figure 1.6.B) (49). It has also been suggested that other proteins can act as Notch ligands. Convincing evidence shows that F3/contactin may be one of such examples (52). 


\subsubsection{Notch target genes}

Only a few downstream genes of the Notch signaling pathway have been identified, despite the large number of developmental processes that are regulated by Notch. In the canonical pathway, RBP-Jא connects with NICD and together they act as a transcriptional activator. The RBP-JK-NICD complex turns on expression of Notch signaling target genes, such as the Hes (Hes1, Hes5 and Hes7) and Hey family genes (Figure 1.7.). These genes encode helix-loop-helix transcription factors that function as transcriptional repressors, directly affecting cell fate decisions as Notch effectors (45, $53,54)$,

There are also other Notch target genes, such as NRARP and Deltex-1 (negative regulators of Notch signaling) $(55,56)$. Notch target genes, which are implicated in cancer include c-myc $(57,58)$, cyclinD1 (59) and p21/Waf1 (60). Other downstream genes are NFkB2 (61), Ifi- 202, Ifi-204, Ifi-D3, and ADAM19 (62). A number of other genes have been described including Notch1 and Notch3, bcl-2 and E2A (63, 64 and $65)$.

In addition to the canonical Notch pathway (via RBP-JK), a non-canonical pathway has been observed. One good example is the interactions between Notch and Wnt signaling pathways, where transduction of Notch signals is facilitated via Wnt pathway components $(66,67)$.

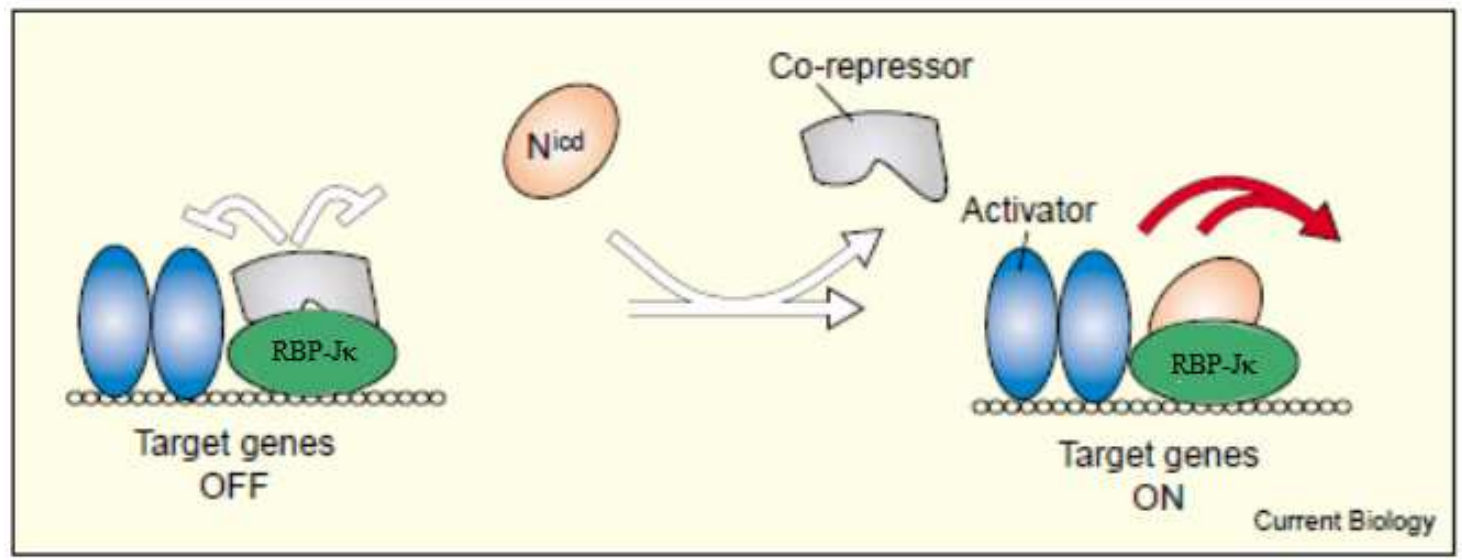

Figure 1.7. The switch model for Notch target gene regulation by RBP-Jк .

In the absence of Notch, DNA-bound RBP-Jא (green) prevents activators from starting transcription. Co-repressors, recruited by RBP-JK, act by local conversion of chromatin. NICD (orange) is able to lighten the repression. RBP-JK-NICD complex cooperate with trans-activators to promote transcription (68). 


\subsubsection{Mechanisms of Notch signaling}

Signaling occurs when the DSL domain of a ligand (Delta, Jagged) binds and interacts with the Notch receptor (69), thus inducing the S2, S3, and S4 cleavages (Figure 1.8.). Two kinds of interaction can be distinguished: positive interaction with ligand presented by neighboring cells, (trans interactions) mediated by EGF repeats 1112 of receptors and inhibitory interaction with a ligand co-expressed in the same cell (cis interactions) which is mediated by repeats 24-29 (70). Many of the EGF repeats bind calcium ions. They play an important role in determining the structure and affinity of Notch receptors to its ligands $(71,72)$. Interaction between receptor and ligand results in shedding of the ectodomain and exposure of an extracellular metalloprotease site ( $\mathrm{S} 2$ site). Notch is then cleaved by transmembrane metalloproteases ADAM. The S3/4 cleavage is an intramembranous cleavage mediated by the presenilin-dependent $\gamma$-secretase complex (73, 74 and 75). This cleavage results in the translocation of the intracellular domain of Notch (NICD) into the nucleus. The $\gamma$-secretase complex is composed of 4 membrane proteins in a 1:1:1:1 stoichiometry of the catalytic component presenilin and the three limiting cofactors nicastrin, Pen2 and Aph1 (76, 77). The $\gamma$-secretase complex has been detected on the cell membrane and in endocytic compartments $(44,78,79)$. There is evidence that the $S 3 / 4$ cleavage can happen on the membrane as well as in endocytic components (44).

After translocation of NICD into the nucleus, the receptor interacts with the transcription factor CSL (CBF1/RBPJk in mammals) by acting as a co-activator of the transcription factor (Figure 1.7.) (80). This active complex recruits transcription factors including $\mathrm{CBP} / \mathrm{p} 300$ and $\mathrm{PCAF}$, promoting histone acetylation and increased expression of Notch target genes (81, 82 and 83). 


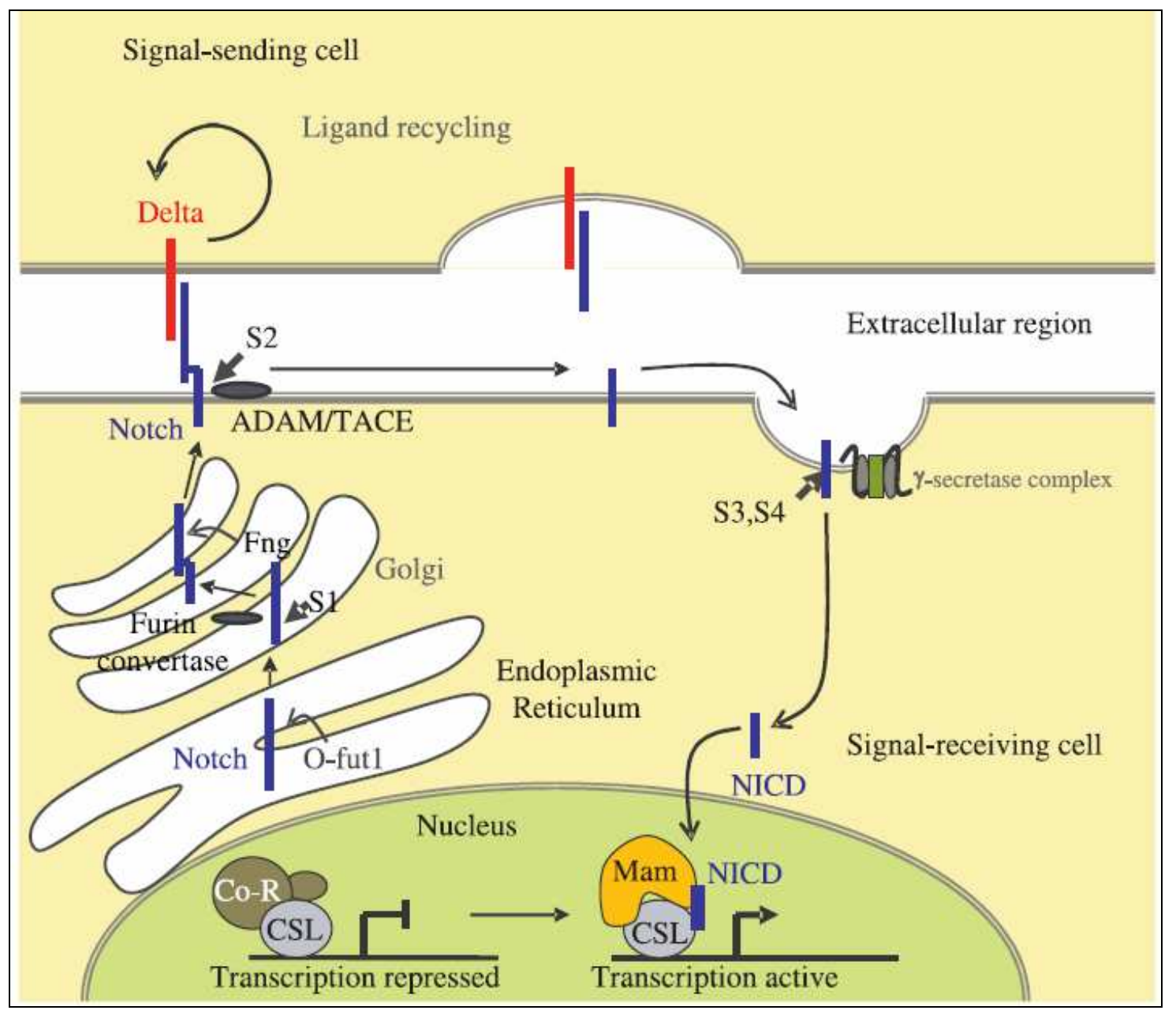

Figure 1.8. Canonical Notch signaling pathway.

The Notch receptor binding ligand undergoes several cleavages. The S2 site is mediated by the proteases ADAM10 or by TACE (TNF-a-converting enzyme). This catalyzes the processing of Notch in the intramembranous S2 and S3 sites by the $\gamma$-secretase complex. Thus, the Notch intracellular domain (NICD) is translocated into the nucleus where it forces dissociation of repressor proteins from CSL/Rbpjк. NICD and CSL/Rbpjк form a ternary complex together with Mastermind (Mam) that recruits transcription factors activating target gene expression. (45).

\subsection{The Notch signaling pathway in lung diseases}

\subsubsection{Chronic obstructive pulmonary disease}

As chronic obstructive pulmonary disease (COPD) develops, there are consistent changes in the airway epithelial with increased basal and secretory cells, a decrease in ciliated cells, a partial shedding of the epithelium and with squamous cell metaplasia (84, 85 and 86). In the airway epithelium of smokers and individuals with COPD, high amounts of PCNA and an increased rate of both cell division and apoptosis were observed $(85,86)$. Immunohistochemistry analysis of COPD lung tissues revealed 
protein expression of receptor Notch2, ligand Jag1 and target genes Hes1, Hes5 in the airway epithelium. It was shown that key Notch pathway genes were downregulated in healthy smokers and smokers with COPD, as compared to nonsmokers (9).

\subsubsection{Asthma}

Asthma is an inflammatory disorder of the conducting airways. A significant percentage of asthma is associated with allergic sensitization. The disease is characterized by a polarized Th-2 (T-helper-2)-type T-cell response (87). Activation of the Notch pathways has been shown to play a role in Th cell differentiation. It was demonstrated that Dl14 plays a role in the initial Th2 differentiation as well as in Th2 cytokine production in an established allergic response (88).

\subsubsection{Pulmonary arterial hypertension}

Pulmonary arterial hypertension $(\mathrm{PAH})$ is described by structural remodeling of small pulmonary arteries and arterioles. As a result, the vessel wall is thickened and the lumen is occluded because of media thickening (proliferation of vascular smooth muscle cells) and intima (endothelial cell) proliferation (89). It was proven that high levels of Notch3 are associated with the development of PAH in humans and experimental models of this disease. Pulmonary hypertensive vascular pathology in a hypoxia mouse model of this disease can be prevented by treatment with a drug which blocks Notch signaling activation (10).

\subsubsection{Lung cancer}

\subsubsection{Non-small lung cancer}

Non small cell lung carcinomas (NSCLC) account for approximately $85 \%$ of all lung cancers. It was shown that alterations of the Notch pathway are frequent in this kind of lung cancer. Decrease of NUMB expression and gain-of-function mutations of the Notch1 gene were observed. Also, the potential growth of NSCLCs depends on Notch signaling (90). It was proven that MRK-003 (a chemical Notch inhibitor) induces apoptosis and reduces tumor growth in vivo in lung cancer cells. These results support the hypothesis that inhibition of Notch activation using a $\gamma$-secretase inhibitor represents a potential new approach for the targeted therapy of lung cancer (91). 


\subsubsection{Small cell lung cancer}

Small cell lung cancer (SCLS) differs from non-small cell lung cancer in that this tumor grows more rapidly, spreads more quickly, and responds better to chemotherapy and radiation. In cultured SCLC cells, Notch signaling leads to a major G1 cell cycle arrest related to p21waf/cip1 reduction, repression of hASH1, and induction of the downstream Ras signaling pathway. It was suggested that in the case of a highly proliferate hASH1-dependent NE neoplasm, Notch signaling activation can be related to growth arrest and reduction in neoplastic potential (92).

\subsection{The Notch signaling pathway in organ fibrosis}

\subsubsection{Pulmonary fibrosis}

Example for an involvement of the Notch system in lung fibrosis stems from some forms of drug-induced interstitial lung disease (ILD), such as those caused by A771726, the active metabolite of leflunomide, inhibits leflunomide dihydroorotate dehydrogenase (DHODH) and induces EMT via Notch dependent manners. In vivo, administration of leflunomide provokes bleomycin-induced EMT in the lung and augments bleomycin-induced pulmonary fibrosis. Treatment of A549 cells with the A771726 metabolite, results in upregulation of Jagged1, 2, Dll1 and Notch1, 3, 4 mRNAs expression. Furthermore, the level of NICD1 in the nuclear extract was increased in the presence of the A771726 and this increase was suppressed by co treatment with the inhibitor of $\gamma$-secretase (DAPT) (95).

\subsubsection{Systemic sclerosis}

Systemic sclerosis (SSc) is a chronic fibrotic disease of unknown etiology. It affects the skin and several internal organs such as the lung, heart and kidneys (94). It was proven that the Notch pathway is activated in SSc and that inhibition of Notch signaling prevents the development of fibrosis in two dermal fibrosis models of inflammation (bleomycin) - dependent and inflammation independent (Tsk-1 mice) (95). The last observation suggests that stimulation of dermal fibroblasts with recombinant human Jag-1-Fc chimera results in an SSc-like phenotype. Also, major release of collagen and differentiation of resting fibroblasts into myofibroblasts was observed. 
Chemical inhibition of Notch signaling or knock-down of its components showed reduced collagen expression in SSc fibroblasts, but not in fibroblasts from healthy donors was proven (96).

\subsubsection{Tubulointerstitial fibrosis}

Tubulointerstitial fibrosis (TIF) is a common factor in the development and progression of chronic kidney disease (97). It was shown that the Notch pathway is activated in patients with TIF and in mouse models of this disease. Expression of Notch in renal epithelial cells is sufficient to induce TIF. Genetic deletion of Notch, specific only to tubular epithelial cells, or chemical blockade of the Notch pathway had a protective effect on animals with induced TIF. It was also confirmed that this effect was mediated by the canonical Notch pathway (via Rbpjк) $(98,99)$.

\subsection{The Notch signaling pathway in lung development}

\subsubsection{Notch inhibition}

Deletion of protein O-fucosyltransferase 1 (Pofut1/post-translation modifier of Notch receptor; 100) and Rbpjк in the lung epithelium shows no influence on the distal airway differentiation, including formation of alveolar sacs, type I and type II cells (AECI and AECII) (101, 102). However, alveolar development is impaired in Lfng (Lunatic Fringe) mutant mice. Lfng enhances Notch receptor activation by Delta ligands and suppresses activation by Jagged ligands (103). The Lfng mice display very poor type I alveolar epithelial cell differentiation starting from the saccule phase of development and during later stages (104).

\subsubsection{Notch activation}

Double transgenic mice with constitutive overexpression of NICD1 in AECII present normal size, branching and lobulation of the lung. However, when NICD1 was constitutively expressed in epithelial cells of the distal lung the differentiation of alveolar epithelial cell types was prevented (Figure 1.9.). The enlarged cysts have been observed instead of normal saccules, built of cells that were lacking markers of the alveolar epithelium but were expressing several markers of the proximal airway 
epithelium. It is worth to notice that cysts occurred specifically in regions of lung where NICD1 was overexpressed (105).

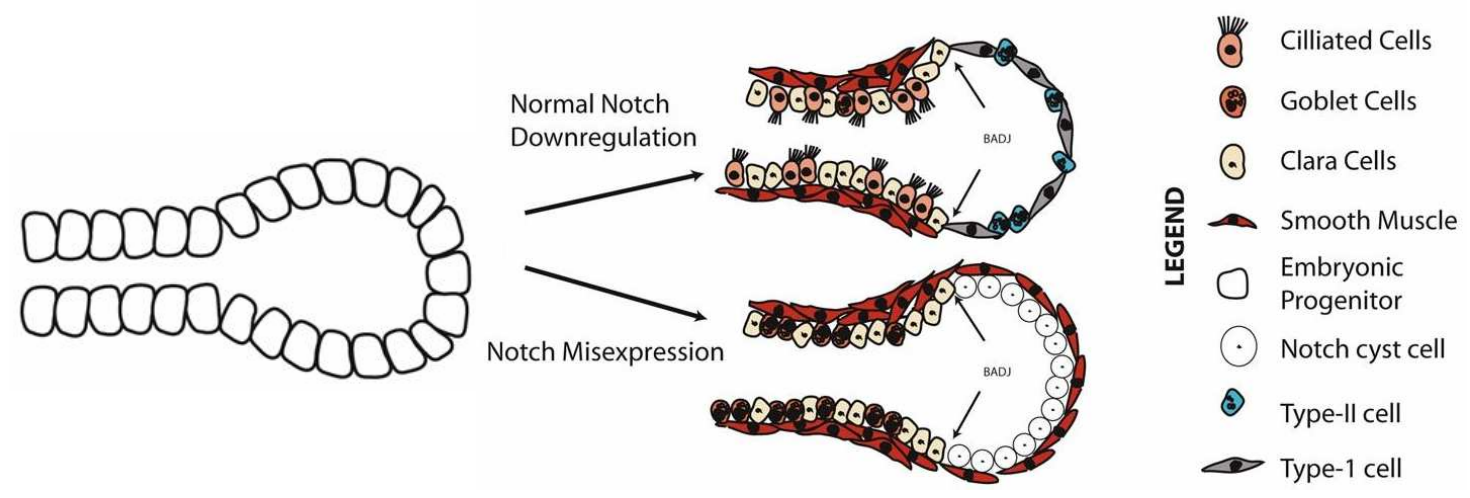

Figure 1.9. Model of Notch action in mouse lung development.

For the proper alveolar development a down-regulation of Notch is required. Constitutive expression of NICD resolves in appearing of a dilated cystic epithelium (modified from 105).

Additionally, the effect of an expression of Notch3 in the peripheral epithelium was also investigated. In the developing lung, altered lung morphology and delayed development, leading to early lethality was observed. Similar to double transgenic, SPC-Cre; NICD1 mice, the inhibition of AEC type II into AEC type I transition was observed in constitutive SPC-NICD3 overexpressing mice. Furthermore, in the lungs of those animals metaplasia of undifferentiated respiratory cells was observed (106). 


\section{Aim of the study}

It is increasingly anticipated that the alveolar epithelial cells play a central role in the pathogenesis of idiopathic pulmonary fibrosis. Because of possibly persistent endogenous triggers and exogenous secondary hits, a permanent repair of the alveolar epithelium is necessary. Developmental pathways (such as TGF $\beta$ and Wnt signaling) have previously been confirmed to play a role in the pathogenesis and progression of IPF. The Notch signaling pathway, being known to be involved in cell fate decisions, differentiation and proliferation during development, may represent another developmental pathway involved in this disease. However, until now, there are no detailed reports with regard to regulation of the Notch pathway in idiopathic pulmonary fibrosis and the influence of Notch on alveolar epithelial proliferation and apoptosis.

In this context, the aim of this thesis was to:

1. analyze the cellular regulation of the Notch signaling pathway (including the Notch receptors and ligands) on a mRNA, protein and immunohistochemical level in the lungs of IPF patients and bleomycin-challenged mice $v s$. the respective controls

2. characterize the impact of the Notch signaling pathway on proliferation and apoptosis of alveolar epithelial cells employing in vitro activation or inhibition strategies

3. elucidate the downstream signaling pathway underlying the regulation of proliferation by the Notch system in mouse alveolar epithelial cells 


\section{Materials and methods}

\subsection{Materials}

\subsubsection{Equipment}

\section{Name}

Bacteria culture incubator

Cell Culture Incubator,Hera Cell

Electrophoresis Chambers

Falcon tubes

Film Casette

Filter Tips: $10 ; 100 ; 1000 \mu 1$

Filter units $0.22 \mu \mathrm{m}$ syringe-driven

Falcons filters: $70 \mu \mathrm{m} ; 40 \mu \mathrm{m} ; 10 \mu \mathrm{m}$

Fluorescence and light microscope

Freezer $+4^{\circ} \mathrm{C}$

Freezer $-20{ }^{\circ} \mathrm{C}$

Frezer $-80^{\circ} \mathrm{C}$

Whatmann paper

Glass bottles: 250, 500, $1000 \mathrm{ml}$

Glass Pipetes

Light microscope

Mini spin centrifuge

Mirax scanner

Multifuge centrifuge

NanoDrop

PCR-thermocycler

Petri Dish

Pipetboy

Pipet tips: P10, P20, P100, P200, P1000

Pipets

\section{Company}

\author{
Heraeus, Germany \\ Heraeus, Germany \\ Bio-Rad, UK \\ Greiner, Germany \\ Kodak, USA \\ Eppendorf, Germany \\ Millipore, USA \\ BD Falcon, USA \\ Leica, Germany \\ Bosch, Germany \\ Bosh, Germany \\ Bosh, Germany
}

Amersham Biosciences, UK

Roth, Germany

Greiner, Germany

LEICA,Germany

VWR, Germany

Zeiss, USA

Heraeus, Germany

PeqLab, Germany

Bio-Rad, Germany

Greiner, Germany

Eppendorf, Germany

Nerbe plus, Germany

Eppendorf, Germany 


\begin{tabular}{|ll|}
\hline Precellys Homogeniser & PeqLab, Germany \\
Radiographic film & Amersham Biosciences, UK \\
Serological pipette: $5,10,25 \mathrm{ml}$ & BD Falcon, USA \\
Tissue Culture Chamber Slides & BD Falcon, USA \\
Tissue Culture Dish 100mm & Greiner, Germany \\
Tissue culture plates: 6, 24, 48 well & BD Falcon, USA \\
Vortex machine & VWR, Germany \\
Water bath & Medingen, Germany \\
Western blot unit & Bio-Rad, Germany \\
\hline
\end{tabular}

\subsubsection{Reagents}

Name

2-(-4-2-hydroxyethyl)-piperazinyl-1-ethansulfonate

(HEPES)

2-mercapto-ethanol

Acetic acid

Acetone

Acrylamide solution, Rotiphorese gel 30

Agarose

Albumine, bovine serum

Ammonium chloride

Ammonium persulfate

Ampicillin sodium

BCАтм Protein Assay Kit

$\beta$-estradiol

$\beta$-mercaptoethanol

Bromophenol blue

Calcium chloride

EDTA-free Protease inhibitor

D-(+)-Glucose

Dharma FECT1

\section{Company}

Sigma-Aldrich, Germany

Sigma-Aldrich, Germany

Sigma-Aldrich, Germany

Fluka Germany

Roth, Germany

Roth, Germany

Sigma-Aldrich, Germany

Sigma-Aldrich, Germany

Sigma-Aldrich, Germany

Sigma-Aldrich, Germany

Thermo Scientific, USA

Sigma-Aldrich, Germany

Sigma-Aldrich, Germany

Sigma-Aldrich, Germany

Sigma-Aldrich, Germany

Roche, Germany

Roth, Germany

Thermo Scientific, USA 


\begin{tabular}{|c|c|}
\hline Dimethyl Sulfoxide & Sigma-Aldrich, Germany \\
\hline Dispase & BD Bioscience, USA \\
\hline DMEM medium & Gibco, Germany \\
\hline DMEM-F12 medium & Gibco, Germany \\
\hline DNA ladder & Eurogentee, Belgium \\
\hline Dnase & Fermentas, Germany \\
\hline Dulbecco's phosphate buffered saline $1 \times$ & PAA, Austria \\
\hline $\begin{array}{l}\text { Amersham ECL }{ }^{\mathrm{TM}} \text { Western Blotting Detection } \\
\text { Kit }\end{array}$ & Amersham Biosciences \\
\hline Ethanol absolut & Fluka, Germany \\
\hline Ethidium bromide & Sigma-Aldrich, Germany \\
\hline Ethylenediamine-tetraacetic acid (EDTA) & Sigma-Aldrich, Germany \\
\hline Fetal calf serum (FCS) & Roth, Germany \\
\hline Formaldehyde & Roth, Germany \\
\hline Gel extraction kit & Qiagen, Germany \\
\hline Glycerol & Roth, Germany \\
\hline Glycine & Roth, Germany \\
\hline Glecergel Mounting Medium & Dako, Denmark \\
\hline Heparin & Ratiopharm, Germany \\
\hline Hydrochloric Acid & Sigma-Aldrich, Germany \\
\hline Hydrocortisone & Sigma-Aldrich, Germany \\
\hline ITS & PAN Biotech, Germany \\
\hline iQ SYBR Green Supermix Kit & Bio-Rad, Germany \\
\hline Kanamycin & Roth, Germany \\
\hline Ketamin $10 \%$ & Betapharm, Germay \\
\hline KOD Hot Start DNA polymerase & Merck, Germany \\
\hline L-Glutamine & Gibco, Germany \\
\hline Lipofectamine & Invitrogen, Germany \\
\hline Magnesium chloride (anhydrous) & Sigma-Aldrich, Germany \\
\hline Methanol & Fluka, Germany \\
\hline Milk powder & Roth, Germany \\
\hline Gel Extraction Kit & Qiagen, Germany \\
\hline N,N,N',N'-Tetramethyl-1-,2-diaminomethane & \\
\hline
\end{tabular}




\begin{tabular}{|c|c|}
\hline (TEMED) & Sigma-Aldrich, Germany \\
\hline Oligo(dT) & Applied Biosystem, USA \\
\hline Omniscript RT Kit & Qiagen, Germany \\
\hline Opti-MEM medium & Invitrogen, Germany \\
\hline Penicillin-Streptomycin & PAA, Austria \\
\hline Plasmid isolation kit & Qiagen, Germany \\
\hline Potassium chloride & Roth, Germany \\
\hline Potassium phosphate monobasic & Sigma-Aldrich, Germany \\
\hline PageRuler Prestained Protein Ladder & Fermentas, Germany \\
\hline Plasmid Mini and Maxi System & Qiagen, Germany \\
\hline PMSF (phenylmethylsulfonyl fluoride) & Thermo Scientific, USA \\
\hline Restriction endonucleases & NEB, USA \\
\hline Restore Western Blot Stripping Buffer & Thermo Scientific, USA \\
\hline RNAse inhibitor & Applied Biosystems, USA \\
\hline RNeasy Mini Kit & Qiagen, Germany \\
\hline Sodium dodecyl sulfate (SDS) & Sigma-Aldrich, Germany \\
\hline Sodium acetate & Sigma-Aldrich, Germany \\
\hline Sodium chloride & Sigma-Aldrich, Germany \\
\hline Sodium citrate tribasic dehydrate & Sigma-Aldrich, Germany \\
\hline Sodium hydroxide & Sigma-Aldrich, Germany \\
\hline Sodium phosphate (monobasic, anhydrous) & Sigma-Aldrich, Germany \\
\hline Streptavidin coated magnetic beads & Invitrogen, Germany \\
\hline T4 DNA ligase & Promega, USA \\
\hline TEMED & Sigma-Aldrich, Germany \\
\hline TOP 10 , competent cells & Invitrogen, Germany \\
\hline Tris & Roth, Germany \\
\hline Triton $\mathrm{X}-100$ & Sigma-Aldrich, Germany \\
\hline Trepan Blue & Sigma-Aldrich, Germany \\
\hline Trypsin/EDTA & PAA, Austria \\
\hline Tween 20 & Sigma-Aldrich, Germany \\
\hline Vectashield mounting medium with DAPI & Vector Labolarories, USA \\
\hline Xylazin $2 \%$ & Ceva, France \\
\hline
\end{tabular}




\subsection{Animal tissues}

All animal studies were performed in accordance with the guidelines of the Ethic Committee of the University of Giessen School of Medicine and approved by the local authorities (Regierungspräsidium Giessen, no. GI20/10-109/2011). Male and female mice (C57BL/6 strain) weighing between 18-20g were used in all experiments. Mice were obtained from Charles River Laboratories, Sulzfeld, Germany. The animals were anaesthetized with isoflurane (Isofluran, Baxter). Bleomycin (Hexal) in a dose of $5 \mathrm{U} / \mathrm{kg}$ body weight was given as aerosol. The animals were orotracheally intubated and mechanically ventilated. A microsprayer (Penn-Century Inc, USA) was filled with $200 \mu \mathrm{l}$ of saline solution containing bleomycin or a $0,9 \%$ saline for control mice. For the sample preparation the left main bronchus was clamped and the right lung was washed (lavaged) three times with $350 \mu \mathrm{l} 0.9 \% \mathrm{NaCl}$ each time. The clamp from the left main bronchus was removed and fixed to the right main bronchus. The bronchus was cut distal from the clamp and the right lung was excised and shock frozen. Before taking the left lung for histology, the lung was flushed to clear it from blood via the right ventricle. Formalin fixation was achieved by filling the lung with $4.5 \%$ formaldehyde solution. Following instillation the lung was carefully removed and transferred into a cup with formaldehyde. After overnight incubation at room temperature, the lung was transferred into an embedding cassette and stored in PBS at $4{ }^{\circ} \mathrm{C}$. This lung tissue was processed in a tissue processor (Leica, ASP 300s) for dehydration and then embedded in paraffin. $3 \mu \mathrm{m}$ thin sections were cut with a microtome for further analysis.

\subsection{Human tissues}

The study was approved by the local research ethics committee, and written consent was obtained from all participants (no. 31/93, 84/93, 94/95, 29/01, 10/6, 111/08). Lung tissue samples were obtained from twelve patients with IPF (mean age $56 \pm 8$ years; four females, eight males) and ten control subjects (mean age $40 \pm 4$ years; five females, five males). Tissue samples were shock frozen or transferred into a cup with formaldehyde solution. After incubation at $4{ }^{\circ} \mathrm{C}$, the lung was transferred into an embedding cassette, buffered in PBS and stored at $4^{\circ} \mathrm{C}$. This lung tissue was processed in a tissue processor (Leica, ASP 300s) Vacuum-dryer for dehydration and then embedded in paraffin. $3 \mu \mathrm{m}$ thin sections were cut with a microtome for further analysis. 


\subsection{Methods}

\subsubsection{Mammalian cell culture}

\subsubsection{MLE 12 cells}

The mouse lung epithelial cell line (MLE 12) (CRL-2110 ATCC; Manassas, VA, USA) were grown in $10 \mathrm{~cm}^{2}$ tissue culture plates in DMEM/F12 medium, supplemented with $2 \%$ fetal bovine serum, insulin $0.005 \mathrm{mg} / \mathrm{ml}$, transferrin $0.01 \mathrm{mg} / \mathrm{ml}$, sodium selenite $30 \mathrm{nM}$, hydrocortisone $10 \mathrm{nM}$, beta-estradiol 10nM and HEPES 10mM in $95 \%$ air; carbon dioxide $\left(\mathrm{CO}_{2}\right), 5 \%$. The cell line was passage when reached $80-90 \%$ confluence. During passage, cells were incubated with $3 \mathrm{ml}$ of trypsin solution for $3 \mathrm{~min}$ at $37^{\circ} \mathrm{C}$, after which $10 \mathrm{ml}$ of culture medium was added to neutralize enzymatic activity of trypsin. MLE 12 cells were diluted 1:15 with medium and passage to a new tissue culture plates.

\subsubsection{Isolation of alveolar epithelial type II cells (AECII)}

Type II alveolar epithelial cells were isolated from the lungs of C57BL/6 mice. Animals were anesthetized by intraperitoneal injection of a mixture of ketamine, xylazine and heparin (in the ratio 2:2:1). The abdominal cavity was opened and the renal artery was severed to exsanguinate the mouse. The lungs were perfused with $10 \mathrm{ml}$ of saline, until visually cleared of blood. Dispase, followed by $0.5 \mathrm{ml}$ of $1 \%$ low-melting-point agarose in DMEM medium, was injected into lungs via the trachea (cannulated with a Vasofix ${ }^{\circledR}$ Safety, Braun). Agarose solution was allowed to solidify for $2 \mathrm{~min}$. Then lungs were separated from the trachea and other connective tissues. The isolated organ was incubated in $2 \mathrm{ml}$ of dispase for $45 \mathrm{~min}$ at room temperature. After this time lungs were dissected in $7 \mathrm{ml}$ of Plus Medium. Lungs were chopped; the resulting crude cell mixture was incubated for 10min at room temperature with gentle shaking. This was followed by subsequent washes with Plus Medium and filtration through $70 \mu \mathrm{m}, 40 \mu \mathrm{m}$ and $10 \mu \mathrm{m}$ Nitex filters. The resulting filtrate was centrifuged at $130 \mathrm{xg}$ at $4^{\circ} \mathrm{C}$ for $10 \mathrm{~min}$ and resuspended in $2 \mathrm{~mL}$ of ER Lysis Buffer. The lysis reaction was stopped by adding Minus Medium $+10 \%$ FCS followed by centrifugation at $130 \mathrm{xg}$ at $4^{\circ} \mathrm{C}$ for $10 \mathrm{~min}$. Obtained cells were counted with Trypan Blue. The following antibodies (BD Bioscience) were then added to the cell suspended 
in $5 \mathrm{ml}$ of Minus media $+10 \% \mathrm{FCS}$ : anti-CD16/32 at $0.75 \mu \mathrm{l} / \mathrm{million}$ cells, anti-CD45 at $0,9 \mu \mathrm{l} / \mathrm{million}$ cells, anti CD-31 at $0,4 \mu \mathrm{l} /$ million cells. Mix was incubated at $37^{\circ} \mathrm{C}$ for 30min, then centrifuge and resuspende in Minus media (216 $\mu \mathrm{l} / \mathrm{million}$ cells). Streptavidin coated magnetic beads were prepared by washing three times in PBS and beads suspension $(11 \mu \mathrm{l} /$ milion cells) was added to cells. The mix was incubated at room temperature for $30 \mathrm{~min}$ and then placed on a magnetic separator for another $15 \mathrm{~min}$. Cell suspension was carefully aspirated from beads, transferred to a new tube and centrifuged as described above. Cells were then resuspended in Minus medium. Freshly isolated cells were immunocytochemically tested for purity percentage by using ProSPC and Fibronectin staining. The AECII pneumocytes were plated either on 48 wells/plate $(150,000 /$ well) or cytospin preparation was done $(80,000$ cells $)$. Cells were grown in Minus Medium supplemented with 1\% FCS. In this study only AECII cells up to day 3 were used. All cultures were maintained in humidified atmosphere with $5 \% \mathrm{CO}_{2}$ at $37^{\circ} \mathrm{C}$.

\begin{tabular}{|ccc|}
\hline Minus medium & Plus Medium & $\begin{array}{c}\text { ER (Erythrocyte) Lysis } \\
\text { Buffer } \\
8,29 \mathrm{~g} \mathrm{NH}_{4} \mathrm{Cl}\end{array}$ \\
$500 \mathrm{ml}$ D-MEM & Minus Medium & $1 \mathrm{~g} \mathrm{KHCO}_{3}$ \\
$10 \mathrm{mM}$ HEPES & supplemented with & $0,037 \mathrm{~g} \mathrm{Na}_{2} \mathrm{EDTA}^{\mathrm{N} \mathrm{H}_{2} \mathrm{O}}$ \\
$1 \%$ Pen-strep & $0.04 \mathrm{mg} / \mathrm{ml} \mathrm{DNase}$ & Add 1000,0 dest. $\mathrm{H}_{2} \mathrm{O}$ \\
& & $\mathrm{pH} 7,4$ \\
\hline
\end{tabular}

\subsubsection{RNA isolation and quantification}

Isolation of RNA from cultured cells was performed according to the manufacturer's instructions provided with Rneasy Mini Kit (Qiagen). By applying $2 \mu \mathrm{l}$ of the sample to a Nanodrop ${ }^{\circledR}$ spectrophotometer the concentration and absorbance (260nm and 280nm) of isolated RNA was measured.

\subsubsection{Reverse transcription}

For the preparation of cDNA, $1 \mu \mathrm{g}$ RNA per sample was used. RNA was copied to cDNA using Omnitranscript RT Kit (Qiagen) and oligo dT (Applied Biosystem). 
Reaction mix was prepared as shown:

\begin{tabular}{|cc|}
\hline Components & Volume/concentration \\
10x Buffer & $2 \mu \mathrm{l}$ \\
dNTPs & $2 \mu \mathrm{l}$ \\
Oligo dT & $1 \mu \mathrm{l}$ \\
RNase-inhibitor & $0.5 \mu \mathrm{l}$ \\
RT & $1 \mu \mathrm{l}$ \\
RNA & up to $1 \mu \mathrm{g}$ \\
$\mathrm{H}_{2} \mathrm{O}$ & up to $20 \mu \mathrm{l}$ \\
\hline
\end{tabular}

cDNA synthesis was achieved by incubating the mix at room temperature for $15 \mathrm{~min}$ and then at $37^{\circ} \mathrm{C}$ for 1 hour. The resulting complementary DNA (cDNA) was further stored at $-20^{\circ} \mathrm{C}$.

\subsubsection{Real time PCR}

Quantitative Real-time PCR is used to quantify and amplify specific sequences of DNA. After each amplification round, the DNA is quantified. Quantification is performed by means of fluorescent dye - SYBR® Green I - that directly binds to double-stranded DNA. The bound dye generates a signal that is proportional to the DNA concentration. Reactions were performed according to the manufacturer's instructions provided with an iQ SYBR Green Supermix Kit (Bio-Rad).

PCR reaction mix was prepared as shown:

\begin{tabular}{|cc|}
\hline Components & Volume/concentration \\
iQ SYBR Green Supermix Kit & $12,5 \mu \mathrm{l}$ \\
Forward primer & $0,4 \mu \mathrm{l}$ \\
Reverse primer & $0,4 \mu \mathrm{l}$ \\
cDNA & $25-50 \mu \mathrm{g}$ \\
$\mathrm{H}_{2} \mathrm{O}$ & up to $25 \mu \mathrm{l}$ \\
\hline
\end{tabular}


Cycling conditions were: $95^{\circ} \mathrm{C}$ for $3 \mathrm{~min}$, followed by 40 cycles of $95^{\circ} \mathrm{C}$ for $10 \mathrm{~s}, 60^{\circ} \mathrm{C}$ for $30 \mathrm{~s}, 1$ cycle $95^{\circ} \mathrm{C}$ for $1 \mathrm{~min}, 55^{\circ} \mathrm{C}$ for $1 \mathrm{~min}$ and 71 cycles of $60^{\circ} \mathrm{C}$ for $10 \mathrm{~s}$. Melting curve analysis was performed to confirm the exclusive amplification of the expected PCR product.

\begin{tabular}{|c|c|c|}
\hline $\begin{array}{c}\text { GENE BANK } \\
\text { ACESSION } \\
\text { NUMBER }\end{array}$ & FORWARD PRIMER (5'-3') & REVERSE PRIMER (5'-3') \\
\hline $\begin{array}{l}\text { Notch1 mouse } \\
\text { NM_008714.3 }\end{array}$ & atggcttcgactgccagctcac & tcggcactgttacagccetggt \\
\hline $\begin{array}{l}\text { Notch2 mouse } \\
\text { NM_010928.2 }\end{array}$ & gggcagctgctgtcaataat & tttggccgcttcataacttc \\
\hline $\begin{array}{l}\text { Notch3 mouse } \\
\text { NM_008716.2 }\end{array}$ & caggccacgtgtcttgaccgaa & tgggctgctctgacattcgtcg \\
\hline $\begin{array}{l}\text { Notch4 mouse } \\
\text { NM_010929.2 }\end{array}$ & tctggatgtggacacctgtggacc & tctctgtggactagccccagtcgt \\
\hline $\begin{array}{c}\text { Dl11 mouse } \\
\text { NM_007865.3 }\end{array}$ & gccttcagcaaccccat & tgttgcgaggtcatcgg \\
\hline $\begin{array}{c}\text { Dll4 mouse } \\
\text { NM_019454.3 }\end{array}$ & tgcctgggaagtatcctcac & tagagtccctgggagagcaa \\
\hline $\begin{array}{l}\text { Jagged1 mouse } \\
\text { NM_013822.5 }\end{array}$ & actgggcctgacaaatacca & tgaggaggtctccttgcag \\
\hline $\begin{array}{l}\text { Jagged2 mouse } \\
\text { NM_010588.2 }\end{array}$ & gcctcctcctgctgctttgtga & atcaggctgctgtcaggcaggt \\
\hline $\begin{array}{l}\text { Hes1 mouse } \\
\text { NM_008235.2 }\end{array}$ & ctgcagcgggcgcagatgac & acacgtggacaggaagcggg \\
\hline $\begin{array}{c}\text { Hey1 mouse } \\
\text { NM_010423.2 }\end{array}$ & ccacgctccgccaccatgaa & cggcgcttctcgatgatgcct \\
\hline $\begin{array}{l}\text { Hey2 mouse } \\
\text { NM_013904 }\end{array}$ & tcgcgatgaagcgecettgt & tcactgagcttgtagcgtgcc \\
\hline $\begin{array}{l}\beta \text {-actin mouse } \\
\text { NM_007393 }\end{array}$ & ctacagcttcaccaccacag & ctcgttgccaatagtgatgac \\
\hline $\begin{array}{l}\text { Notch1 human } \\
\text { NM_017617.3 }\end{array}$ & atggacgtcaatgtccgc & ccctggtagatgaagtcgga \\
\hline $\begin{array}{l}\text { Notch2 human } \\
\text { NM_024408.3 }\end{array}$ & catggccaatagcaatcctt & tcacaacgaggtcctgcata \\
\hline $\begin{array}{l}\text { Notch3 human } \\
\text { NM_000435.2 }\end{array}$ & ccgatgtcaacgagtgtctg & aatgtccacctcgcaatagg \\
\hline
\end{tabular}




\begin{tabular}{|c|c|c|}
\hline $\begin{array}{c}\text { Notch4 human } \\
\text { NM_004557.3 }\end{array}$ & gaccagaaagacaaggccaa & aaccacgtcacacacacat \\
\hline $\begin{array}{c}\text { DLL1 human } \\
\text { NM_005618.3 }\end{array}$ & gaatctgtgtggagagcttcaat & gtcgactccttcagtctgcc \\
\hline $\begin{array}{c}\text { DLL4 human } \\
\text { NM_019074.3 }\end{array}$ & tctgacccacagctagggag & tctcgctcatcatcgaagc \\
\hline $\begin{array}{c}\text { Jagged1 human } \\
\text { NM_000214.2 }\end{array}$ & caagtgccaccgtttctaca & agtcgggaggcaaattcac \\
\hline $\begin{array}{c}\text { Jagged2 human } \\
\text { NM_145159.1 }\end{array}$ & gatcccggagcaaatgg & ggccacctggacaataactg \\
\hline $\begin{array}{l}\text { B-actin human } \\
\text { NM_007393 }\end{array}$ & acagagcctcgctttgccg & acatgccggagccgttgtcg \\
\hline
\end{tabular}

Table 1. List of primers used for Real time PCR.

The primers used for qPCR were designed with the help of the online program PrimerBLAST (http://www.ncbi.nlm.nih.gov/tools/primer-blast/). All primer sequences are listed in Table 1. A $\beta$-actin gene was used as the reference gene in all quantitative Real time PCR reactions. The relative transcript abundance of a gene was presented as $\Delta \mathrm{Ct}$ values $(\Delta \mathrm{Ct}=\mathrm{Ct}$ reference $-\mathrm{Ct}$ target $)$.

\subsubsection{Protein isolation and quantification}

Harvested cells and frozen lung homogenate specimen were lysed in lysis buffer, which contained a protease inhibitor cocktail and PMSF. Lysates were incubated on ice for $30 \mathrm{~min}$, followed by centrifugation $12000 \mathrm{rpm}$ for $10 \mathrm{~min}$ at $4^{\circ} \mathrm{C}$. Supernatants were stored in $-80^{\circ} \mathrm{C}$. Quantification of protein was performed using $\mathrm{BCA}^{\mathrm{TM}}$ Protein Assay Kit (Pierce) according to the manufacturer's instructions. As a standard different bovine serum albumin (BSA) concentrations were used.

\begin{tabular}{|c|}
\hline Lysis buffer: \\
$50 \mathrm{mM} \mathrm{Tris}$ \\
$50 \mathrm{mM} \mathrm{NaCl}$ \\
$5 \mathrm{mM} \mathrm{EDTA}$ \\
$1 \%$ Triton X-100 \\
$0.5 \%$ Sodium deoxycholat \\
\hline
\end{tabular}




\subsubsection{SDS polyacrylamide gel electrophoresis}

The denaturating SDS polyacrylamid gel electrophoresis (SDS-PAGE) was used to separate proteins electrophoretically according to their molecular weight. Protein sample from tissue or cells were reduced (by adding 10\% $\beta$-mercaptoethanol) and boiled for $10 \mathrm{~min}$ in $4 \mathrm{x}$ loading buffer and then cooled on ice for $5 \mathrm{~min}$. The samples were vortexed and collected by brief centrifugation. This mix was loaded into the SDS acrylamide gel and in the presence of 1 x electrode buffer, the electrophoresis was performed at $100 \mathrm{~V}$.

\section{Separating Gel, $10 \mathrm{ml}$}

\begin{tabular}{|cccc|}
\hline & $\mathbf{8 \%}$ & $\mathbf{1 0 \%}$ & $\mathbf{1 5 \%}$ \\
A.dest. & $3,87 \mathrm{ml}$ & $3,2 \mathrm{ml}$ & $1,53 \mathrm{ml}$ \\
$\mathbf{1 , 1 2 5 M}$ Tris, pH 8,8 & $3,33 \mathrm{ml}$ & $3,33 \mathrm{ml}$ & $3,33 \mathrm{ml}$ \\
Acylamide/Bisacrylamide & $2,66 \mathrm{ml}$ & $3,33 \mathrm{ml}$ & $5,0 \mathrm{ml}$ \\
$(\mathbf{3 0 \% / 0 , 8 \% )}$ & & & $100 \mu \mathrm{l}$ \\
$\mathbf{1 0 \%}$ SDS & $100 \mu \mathrm{l}$ & $100 \mu \mathrm{l}$ & $10 \mu \mathrm{l}$ \\
TEMED & $10 \mu \mathrm{l}$ & $10 \mu \mathrm{l}$ & $50 \mu \mathrm{l}$ \\
\hline $\mathbf{1 0 \%}$ APS & $50 \mu \mathrm{l}$ & $50 \mu \mathrm{l}$ & \\
\hline
\end{tabular}

Stacking Gel, 10 ml

\begin{tabular}{|cc|}
\hline A.dest. & $6,57 \mathrm{ml}$ \\
$\mathbf{0 , 6 2 5 M}$ Tris, pH 6,8 & $2,0 \mathrm{ml}$ \\
Acylamide/Bisacrylamide & $1,33 \mathrm{ml}$ \\
$(\mathbf{3 0 \%} / \mathbf{0 , 8 \% )}$ & \\
$\mathbf{1 0 \%}$ SDS & $100 \mu \mathrm{l}$ \\
TEMED & $10 \mu \mathrm{l}$ \\
$\mathbf{1 0 \%}$ APS & $100 \mu \mathrm{l}$ \\
\hline
\end{tabular}




\begin{tabular}{|cc|}
\hline $\mathbf{4}$ x Loading buffer: & Electrode buffer 10x: \\
$5 \mathrm{~g}$ SDS & $30 \mathrm{~g}$ Tris \\
$25 \mathrm{ml} 0,625 \mathrm{M}$ Tris- $\mathrm{HCl} \mathrm{pH} 6.8$ & $144 \mathrm{~g}$ Glycine \\
$40 \mathrm{ml}$ Glycerol & $10 \mathrm{~g}$ SDS \\
$0,0005 \mathrm{~g}$ Bromphenolblue & Add dest. $\mathrm{H}_{2} 0$ to $1000 \mathrm{ml}$ \\
Add dest. $\mathrm{H}_{2} 0$ to $100 \mathrm{ml}$ & \\
\hline
\end{tabular}

\subsubsection{Protein blotting}

Proteins separated on the SDS poly-acrylamide gel were transferred into PVDF membrane (Amersham) using the semi-dry technique in a transfer buffer.

\begin{tabular}{|c|}
\hline Transfer buffer: \\
$4,85 \mathrm{~g}$ Tris \\
$22,51 \mathrm{~g}$ Glycine \\
$400 \mathrm{ml} \mathrm{MeOH}$ \\
Add dest. $\mathrm{H}_{2} \mathrm{O}$ to $2000 \mathrm{ml}$ \\
\hline
\end{tabular}

\subsubsection{Protein detection}

PVDF membranes with transferred proteins were blocked in 5\% non-fat dry milk in TBST for $2 \mathrm{~h}$ at room temperature. After blocking, membranes were incubated at $4^{\circ} \mathrm{C}$ overnight with one of the antibodies listed in Table 2 . The next day, membranes were washed $3 \times 10 \mathrm{~min} / \mathrm{TBST}$ buffer and were incubated for $1 \mathrm{~h}$ with HRP-conjugated secondary antibody (Dako) and next washed again with TBST buffer. Proteins on the membrane were detected using ECL Western Blotting Reagent (Amersham), according to the manufacturer's instructions provided with the kit. In order to re-probe membranes with $\beta$-actin or another antibody, membranes were stripped for $15 \mathrm{~min}$ in commercially available Stripping Buffer (Pierce) and used once more for protein detection. 


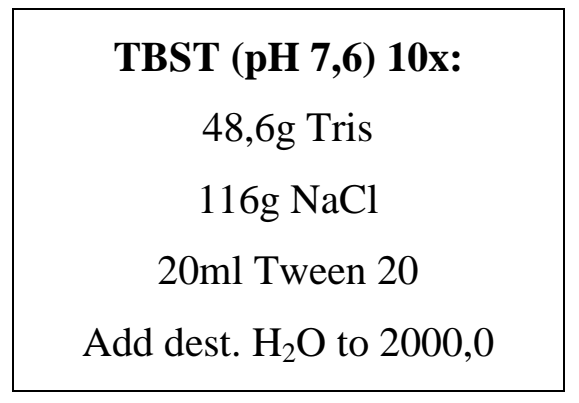

\begin{tabular}{|c|c|c|c|c|c|}
\hline \multirow{2}{*}{ Name } & \multirow{2}{*}{ Source } & \multirow{2}{*}{ Dilution } & \multicolumn{2}{|c|}{ Species } & \multirow{2}{*}{ Company } \\
\hline & & & Human & Mouse & \\
\hline \multirow{2}{*}{ NICD1 } & Rabbit & $1: 700$ & - & $X$ & Abcam \\
\hline & Sheep & $1: 600$ & $X$ & - & R\&D Systems \\
\hline NICD2 & Rabbit & $1: 1000$ & $X$ & $X$ & Abcam \\
\hline NICD3 & Rabbit & $1: 1000$ & $\mathrm{X}$ & $\mathrm{X}$ & Abcam \\
\hline \multirow{2}{*}{ NICD4 } & Rabbit & $1: 500$ & - & $X$ & Sigma-Aldrich \\
\hline & Mouse & $1: 1000$ & $\mathrm{X}$ & - & Cell Signaling \\
\hline Delta1 & Goat & $1: 1000$ & $X$ & $X$ & R\&D Systems \\
\hline \multirow{2}{*}{ Delta3 } & Rabbit & $1: 750$ & - & $X$ & Cell Signaling \\
\hline & Mouse & $1: 500$ & $\mathrm{X}$ & - & R\&D Systems \\
\hline Delta4 & Goat & $1: 750$ & - & $\mathrm{X}$ & R\&D Systems \\
\hline Jagged1 & Rabbit & $1: 300$ & $X$ & - & Santa Cruz \\
\hline Hes1 & Goat & $1: 500$ & $X$ & - & R\&D Systems \\
\hline PCNA & Rabbit & $1: 1500$ & - & $X$ & Abcam \\
\hline Cl.caspase-3 & Rabbit & $1: 500$ & - & $\mathrm{X}$ & Trevigen \\
\hline \multirow[b]{2}{*}{$\beta$-actin } & Rabbit & $1: 4000$ & - & $\mathrm{X}$ & Abcam \\
\hline & Mouse & 1:4000 & $\mathrm{X}$ & - & Abcam \\
\hline
\end{tabular}

Table 2. List of primary antibodies used in Western Blot. 


\subsubsection{Densitometry}

Protein densitometry was measured using AlphaEaseFC software. $\beta$-actin served as a loading control.

\subsubsection{Immunohistochemistry}

To localize and assess the expression of particular proteins in human and mouse lung sections, immunohistochemical analysis was performed using a standardized streptavidin-biotin systems kit according to the manufacturer's instructions (ZytoChem Plus AP Kit, Broad Spektrum and ZytoChem Plus HRP Kit, Broad Spektrum, Zytomed). Paraffin-embedded, formalin-fixed lung tissue was sectioned and used for immunohistochemical analysis. The antibodies from Table 3 were used. Sections were deparaffinized at $60^{\circ} \mathrm{C}$ for $1 \mathrm{~h}$ and then $10 \mathrm{~min}$ in xylene. After dehydration, using a stepwise decrease in ethanol concentration gradient $(99.6 \%>96 \%>80 \%>70 \%>50 \%)$, sections were washed in 1x PBS. Antigen retrieval was performed in citrate buffer $\left(\mathrm{pH} \mathrm{6.0)}\right.$ for $20 \mathrm{~min}$ at $100^{\circ} \mathrm{C}$. Slides were washed three times for $5 \mathrm{~min}$ in $1 \times$ PBS. Counterstaining was performed with haemalaun for $2 \mathrm{~min}$ followed by washing the slides under running tap water, which resulted in blue nuclei. Sections were then mounted with a glycerol mounting medium (Dako), allowed to dry and evaluated by usage of a MIRAX scanner. Negative controls were obtained in all cases by omitting the primary antibody.

\begin{tabular}{|c|}
\hline PBS $(\mathbf{p H} 7, \mathbf{4}) \mathbf{1 0 x}:$ \\
$80 \mathrm{~g} \mathrm{NaCl}$ \\
$2 \mathrm{~g} \mathrm{KCl}$ \\
$14,4 \mathrm{~g} \mathrm{Na}_{2} \mathrm{HPO}_{4}$ \\
$2,4 \mathrm{~g} \mathrm{KH}_{2} \mathrm{PO}_{4}$ \\
Add dest. $\mathrm{H}_{2} \mathrm{O}$ to $1000 \mathrm{ml}$ \\
\hline
\end{tabular}




\begin{tabular}{|c|c|c|c|c|c|}
\hline \multirow{2}{*}{ Name } & \multirow{2}{*}{ Source } & \multirow{2}{*}{ Dilution } & \multicolumn{2}{|c|}{ Species } & \multirow{2}{*}{ Company } \\
\cline { 4 - 5 } & & & Human & Mouse & \\
\hline \multirow{2}{*}{ NICD1 } & Rabbit & $1: 200$ & $X$ & $X$ & Abcam \\
\hline DLL1 & Rabbit & $1: 150$ & - & $X$ & Rockland \\
\cline { 3 - 6 } & Rabbit & $1: 100$ & $X$ & - & Abcam \\
\hline Hes1 & Goat & $1: 50$ & $X$ & - & R\&D Systems \\
\hline Pro -SPC & Rabbit & $1: 750$ & $X$ & $X$ & Millipore \\
\hline Fibronectin & Rabbit & $1: 250$ & $X$ & - & Abcam \\
\hline Ki67 & Rabbit & $1: 400$ & $X$ & - & Sigma-Aldrich \\
\hline
\end{tabular}

Table 3. List of primary antibodies used in Immunohistochemistry.

\subsubsection{Immunocytochemistry}

Immunocytochemistry method was performed to localize specific proteins in the cell. Cells were seeded or in 8-well chamber slides (MLE 12) or cytospin preparation was used (AECII). Cells were fixed with $4 \%$ paraformaldehyde for $10 \mathrm{~min}$, permeabilized with $0.2 \%$ Triton X-100. After washing 3 x 10min with PBS, cells were blocked in 5\% BSA in PBS for $1 \mathrm{~h}$ at room temperature and then incubated with the appropriate primary antibody (Table 4.) overnight at $4^{\circ} \mathrm{C}$. After washing $3 \times 10 \mathrm{~min}$ with PBS and $1 \mathrm{~h}$ incubation with a secondary antibody (Invitrogen), slides were mounted with Vectashield mounting medium with DAPI (4',6-diamidyno-2-fenyloindol) (VectorLab). Controls were performed omitting the primary antibody. Visualization of protein localization was performed using a Leica DMR microscope and photographed using MetaMorph 7.0 software. 


\begin{tabular}{|c|c|c|c|c|c|}
\hline \multirow{2}{*}{ Name } & \multirow{2}{*}{ Source } & \multirow{2}{*}{ Dilution } & \multicolumn{2}{|c|}{ Species } & \multirow{2}{*}{ Company } \\
\cline { 4 - 6 } & & & Human & Mouse & \\
\hline NICD1 & Rabbit & $1: 1000$ & - & $X$ & Abcam \\
\hline Pro-SPC & Rabbit & $1: 1250$ & - & $X$ & Millipore \\
\hline E-cadherin & Rabbit & $1: 400$ & - & $X$ & Cell Signaling \\
\hline$\alpha-S M A$ & Rabbit & $1: 200$ & - & $X$ & Abcam \\
\hline Fibronectin & Rabbit & $1: 200$ & - & $X$ & Abcam \\
\hline Ki67 & Rabbit & $1: 500$ & - & $X$ & Abcam \\
\hline
\end{tabular}

Table 4. List of primary antibodies used in Immunocytochemistry.

\subsubsection{Cloning of the mouse intracellular Notch1 receptor}

\subsubsection{PCR product purification}

To subclone the intracellular Notch1 gene into an expression vector, the DNA template was analyzed for the appropriate restriction sites (NheI and XmaI) using the NEBcutter 2.0 software and appropriate primers were designed. Cleaved Notch1 cDNA was amplified from total lung RNA by PCR (with KOD Hot start polymerase, Merck) using the forward and reverse primers 5'- CGT GGC TCC ATT GTC TAC CT3' and 5'- CAC ACA GGG AAC TTC ACC CT-3', respectively. Restriction sites, Kozak sequence and ATG codon was added to the amplified product by PCR using the forward and reverse primers 5'- GCC ACC ATG TCC CGC AAG C-3', 5'- GCT AGC GCC ACC ATG TCC-3' and 5'- CCC GGG TTA TTT AAA TGC CTC TGG-3', respectively. The created DNA fragment was analyzed and separated by agarose gel electrophoresis, excised and gel-purified using a commercially available QIAquick Gel Extraction Kit (Qiagen) according to the manufacturer's protocol. 


\subsubsection{Ligation of PCR products into the pGEM-T Easy vector}

The purified PCR product was ligated into pGEM-T Easy vector (Promega) using the ligation mix presented above.

\begin{tabular}{|cc|}
\hline Components & Volume/concentration \\
Ligase 10x Buffer & $1 \mu \mathrm{l}$ \\
pGEMT-T Easy Vector (50ng) & $100 \mathrm{ng}$ \\
Purified PCR product & $17 \mathrm{ng}$ \\
T4 DNA ligase & $1 \mathrm{U}$ \\
Autoclaved, deionized water & up to $10 \mu \mathrm{l}$ \\
\hline
\end{tabular}

This reaction mix was incubated overnight at $16^{\circ} \mathrm{C}$.

\subsubsection{Transformation and amplification of plasmid}

After ligation, plasmids were transformed in competent $E$. coli TOP10 cells (Invitrogen) for further amplification. Up to 100ng were added into a vial of One Shot ${ }^{\circledR}$ cells and mixed gently. Samples were incubated on ice for $30 \mathrm{~min}$ and then the cells were heat-shocked for $30 \mathrm{~s}$ at $42^{\circ} \mathrm{C}$, without shaking, and placed on ice for $2 \mathrm{~min}$. Aseptically, 250 $\mu 1$ of pre-warmed S.O.C. medium (Invitrogen) were added to each vial and shaken at $37^{\circ} \mathrm{C}$ for $1 \mathrm{~h}$ at $225 \mathrm{rpm}$. Afterwards $100 \mu \mathrm{l}$ of cells from each transformation were spread on a pre-warmed selective plate (X-Gal and IPTG were added to the LB medium) and incubate overnight at $37^{\circ} \mathrm{C}$. After overnight incubation, individual bacterial colonies were picked from the plate on the following day and inoculated in LB medium containing the appropriate antibiotics. The bacterial tubes were shaken overnight at $37^{\circ} \mathrm{C}$ at $225 \mathrm{rpm}$. Plasmids were subsequently isolated using a Qiagen plasmid isolation kit.

\subsubsection{Subcloning into the mammalian expression vector}

In order to subclone NICD1 from pGEM-T Easy vector into a mammalian expression vector, pIRES-DsRed2, both the empty expression vector and pGEM-T Easy plasmid, containing the mouse NICD1 PCR product, were digested with the same 
restriction enzymes for $1-3 \mathrm{~h}$ at $37^{\circ} \mathrm{C}$, separated by agarose gel electrophorsis and gelpurified. The purified PCR product and the linearized purified vector were ligated as described in the previous chapter 3.4.12.2. The following steps were also performed as described in the previous chapter 3.4.12.3. The intracellular Notch1 construct was verified by sequencing.

\subsubsection{Transient plasmid DNA transfection}

Transient transfection of plasmids is a technique to transfer DNA into eukaryotic cells. In this method transfected DNA is not integrated into the host genome. NICD1 was transiently transfected into MLE 12 cell reagent using Lipofectamine $^{\mathrm{TM}} 2000$ (Invitrogen) according to the manufacturer's instruction. Briefly, Lipofectamine and NICD1 plasmid were added separately to OptiMEM, mixed and incubated at room temperature for $5 \mathrm{~min}$. NICD1 and Lipofectamine were incubated together for another $20 \mathrm{~min}$ at room temperature and were added to the cells next.

\subsubsection{Antisense Oligonucleotides}

The siRNA oligonucleotides specific to mouse POFUT1 mRNA (D-059834-01 siRNA) were obtained from Thermo Scientific. MLE 12 cells were transiently transfected with $60 \mathrm{nM}$ POFUT1 siRNA or non-specific siRNA using a DharmaFECT1 reagent (Thermo Scientific). Briefly, DharmaFECT1 was added to OptiMEM medium and incubated for 5min. siPOFUT1 or non-specific siRNA was added to OptiMEM and transferred into DharmaFECT1 and OptiMEM mix, after 5min of incubation. The siRNA and DharmaFECT1 mix was incubated for another 20min at room temperature, followed by addition of the complete medium without antibiotics. Prepared solution was added directly to the cells.

\subsubsection{Proliferation assay}

The primary, mouse alveolar epithelial type 2 cells (AECII) or MLE 12 cells were grown in 48-well plates in low serum DMEM medium and then stimulated with a $\gamma$-secretase inhibitor, $10 \mu \mathrm{M}$ DAPT (Tocris) for 54h. MLE 12 cells were additionally transfected with NICD1 plasmid or POFUT1 siRNA. After 24-72h the cells were exposed to [ ${ }^{3} \mathrm{H}$ ] Thymidine $(0.2 \mu \mathrm{Ci}$ per well, PerkinElmer) for $6-12 \mathrm{~h}$, rinsed three times 
with PBS and solubilized with $0.2 \mathrm{ml} 0.5 \mathrm{M}$ sodium hydroxide; $0.1 \mathrm{ml}$ of the solubilized

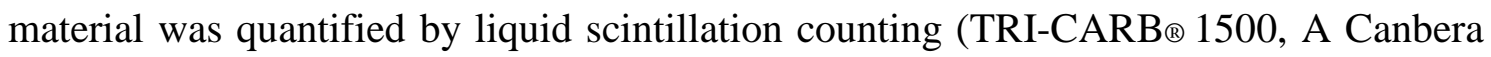
Company, USA).

\subsubsection{Cell death assay}

To quantified cell death of MLE 12 cells LDH assay was performed according to the manufacturer's instruction. Mainly, LDH assay is based on lactate dehydragenase (LDH) which is a stable enzyme, present in all cell types and rapidly released into the cell culture medium upon damage of the plasma membrane. Briefly, cells were stimulated with a $\gamma$-secretase inhibitor, $10 \mu \mathrm{M}$ DAPT (Tocris) for $54 \mathrm{~h}$, transiently transfected with NICD1 plasmid (24h) or POFUT1 siRNA (72h) and stimulated with the apoptosis inducer staurosporine $1 \mathrm{mg} / \mathrm{ml}$ (Sigma-Aldrich) for $5 \mathrm{~h}$.

\subsubsection{Microarray experiments}

Lung tissues were collected from patients with interstitial lung disease undergoing lung transplantation at the Universities of Giessen (Germany) or Vienna (Austria). All patients were accessed, diagnosed, and treated in expert centers for interstitial lung disease. Nontransplanted donor lung tissue showing no evidence of interstitial lung disease served as healthy controls. Laser-Microdissection of donor and patient lungs was performed as described previously (107). Cryosections from lung tissue were mounted on glass slides. After short haemalaun staining, septa were microdissected under optical control using the Laser Microbeam System (P.A.L.M.). IPF and donor samples were competitively hybridized on Agilent whole human genome arrays (G4112A, Agilent).

Mouse lung epithelial cells (MLE 12) were transiently transfected with the pIRES dsRed2 NICD1 overexpressing vector or pIRES dsRd2 vector for $12 \mathrm{~h}, 24 \mathrm{~h}$ and 48h, followed by the Agilent whole mouse genome array (G4122F, Agilent) analysis of RNA expression.

Briefly, RNA was isolated using the RNeasy kit (Qiagen) following the kit instructions. Total RNA was reverse-transcribed, preamplified, and labeled using the BD Atlas SMART Fluorescent Probe Amplification Kit (Clontech Laboratories). RNA was subjected to reverse transcription. cDNA obtained from the reverse transcription was amplified with 22 SMART PCR cycles. The dsDNA products were 
labeled by four additional PCR cycles in the presence of aminoallylated UTP, and then coupled with monofunctional reactive Cy3- and Cy5-dyes (Amersham). The labeled dsDNA was purified with the Qiaquick PCR Purification Kit (Qiagen) following the kit instructions. After the purification procedure concentration, quality (RNA absorbance ratio measured at 260/280 $\mathrm{nm}$ ) and degree of incorporation of fluorescent dyes (Cyanine 3-labeled and Cyanine 5-labeled concentration) was recorded by spectrophotometer (Agilent Bioanalyzer 2100). Samples were competitively hybridized on Agilent whole human genome arrays (G4112A) or Agilent whole mouse genome array (G4122F, Agilent) according to Agilent's protocol. After hybridization, slides were washed and afterwards scanned with the Axon 4100A (Molecular Devices, Munich, Germany).

\subsubsection{Statistical analysis of data}

If not indicated differently, values are presented as mean \pm SEM. The mean of indicated groups were compared using unpaired Student $t$-tests. A level of $\mathrm{p}<0.05$ was considered statistically significant. NS, not significant 


\section{Results}

\subsection{Identification of differently regulated pathways in septae from IPF vs. healthy organ donors}

It is known that alveolar re-epithelialization appears disturbed in IPF. The reasons for the abnormal reactions of the alveolar epithelial cells (AECs) upon injury are unknown. Some of them may be the answer to the initial insult, whereas others may be the result of accelerated epithelial cell proliferation/migration (11). To investigate which developmental pathway may play a role in the epithelial regeneration response in IPF, microarray analysis was performed on microdissected septae and lung homogenates from IPF and organ donor lungs (Figure 4.1.). In microdissected septae from histological „,normal” appearing areas of IPF lungs TGF $\beta$, Wnt and Notch signaling pathways were formed to be differentially regulated when compared to septae of healthy organ donors. We assumed that septae isolated from those still "normal" appearing areas of the lung could represent early stages of the disease. In the "fibrotic" areas, representing the end-stage of disease $v s$. septae of healthy organ donors, mitogenactivated protein kinase (MAPK), vascular endothelial growth factor (VEGF) and mTOR pathways were suggested to be differently regulated. On the level of lung homogenates only the mTOR pathway appeared to be differentially regulated (Figure 4.1.). 


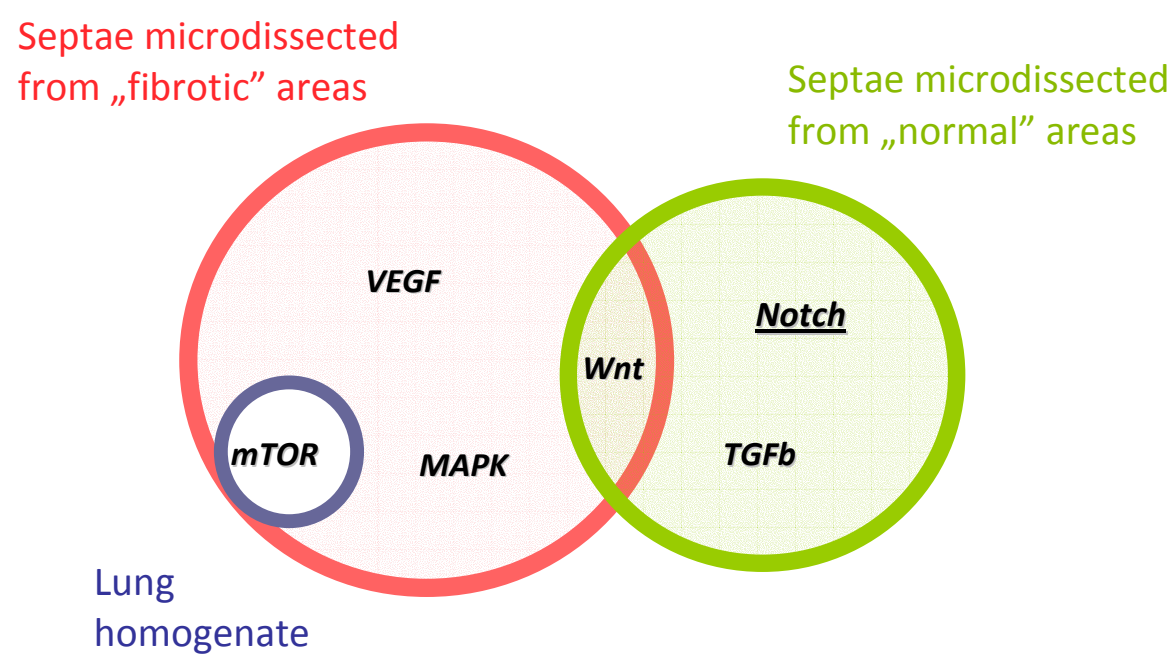

Figure 4.1. Pathway analyses performed on a data obtained from a microarray experiments on microdissected septae and lung homogenates from IPF vs. healthy organ donors.

\subsection{Analysis of the Notch signaling pathway in lungs of patients with idiopathic pulmonary fibrosis}

\subsubsection{Expression analysis of Notch receptors and ligands}

To investigate potential changes in the levels of Notch signaling pathway elements in human lungs, mRNA and protein expression of Notch receptors and ligands was analyzed. mRNA and proteins were isolated from human lung homogenates of transplanted IPF and organ donors. The mRNA expression of Notch pathway elements were analyzed by Real-time PCR (Figure 4.2.A). We did not observed any significant differences in expression of analyzed genes in IPF compared to healthy donor samples. The protein levels of Notch receptors (Figure 4.2.B and C) and ligands (Figure 4.2.D and E) were determined by Western blot. No significant changes in the expression of Notch pathway elements were observed with the exception of the intracellular domain of Notch1 receptor (NICD1) and DLL1 which were found to be significantly increased in IPF vs. donor lungs (Figure 4.2.B-E). 
A
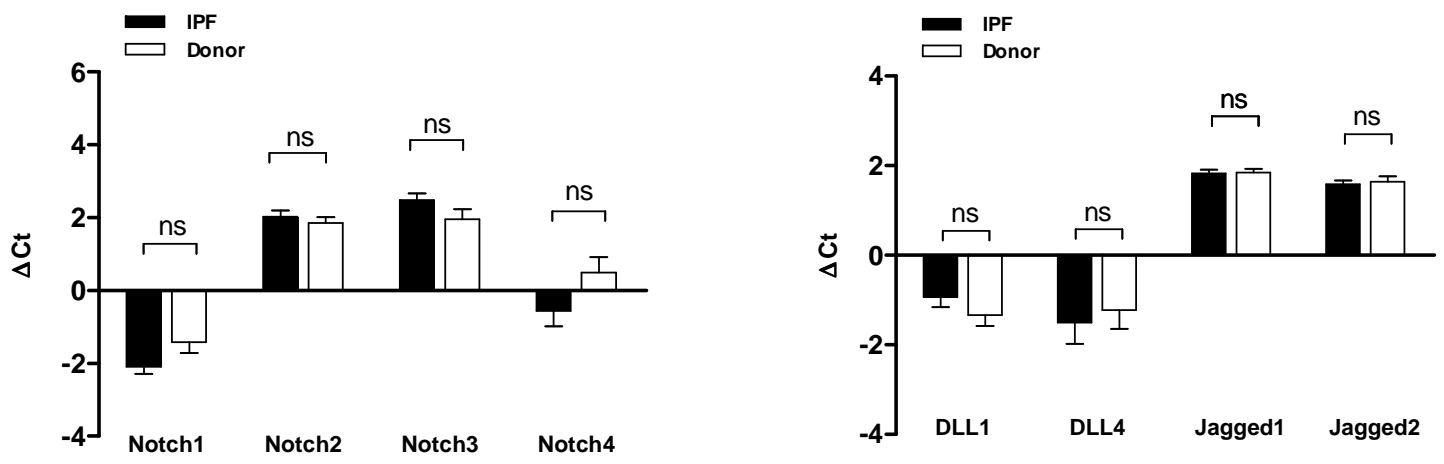

\section{B}

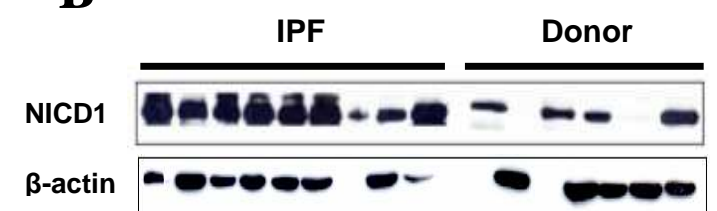

$110 \mathrm{kDa}$

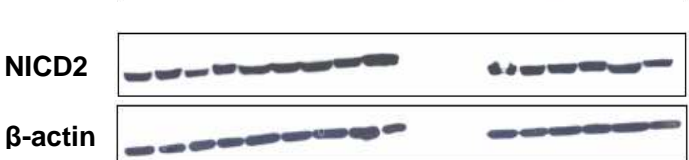

$42 \mathrm{kDa}$

C

$80 \mathrm{kDa}$
$42 \mathrm{kDa}$
$90 \mathrm{kDa}$
$42 \mathrm{kDa}$
$80 \mathrm{kDa}$
$42 \mathrm{kDa}$

D

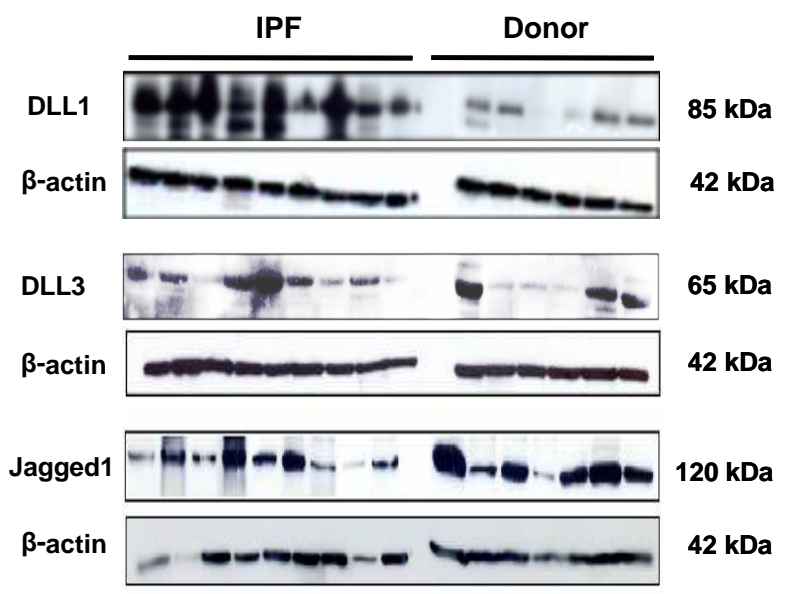

$\mathbf{E}$

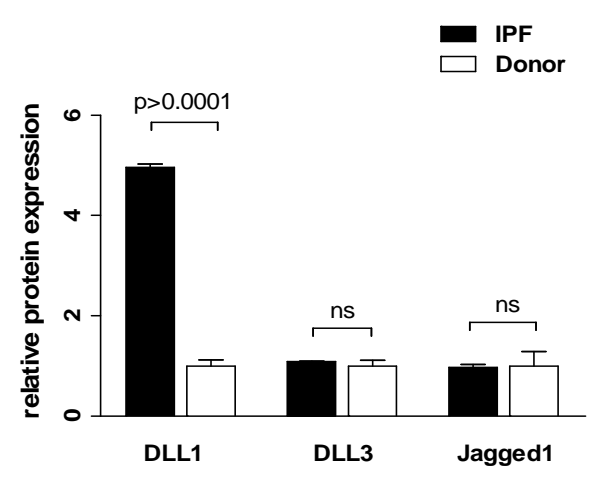


Figure 4.2. Expression analysis of Notch receptors and ligands in lung homogenates of organ donors and IPF patients.

(A) Real-time PCR analysis of Notch receptors and ligands in lung homogenates from organ donors and IPF patients. Given is the fold-increase in mRNA normalized to $\beta$-actin expression. (B) Expression of Notch receptors in lung homogenates was analysed by Western blot in lung homogenates from organ donors and IPF patients. $\beta$-actin served as a loading control. (C) Densitometric analysis of Notch receptors, normalized to control. (D) Notch ligands expression was analysed by Western blot in lung homogenates from healthy donors and IPF patients. $\beta$-actin served as a loading control. (E) Densitometric analysis of Notch ligands, normalized to control. All values are given as mean \pm SEM $(n \geq 6)$. Statistical significance was assured by Student's t-test. Significance levels are indicated.

\subsubsection{Localization of NICD1 and DLL1 in the lungs of patients with idiopathic pulmonary fibrosis}

To identify the cell-specific expression of NICD1 and DLL1, immunohistochemistry was performed on the sections obtained from IPF patients and organ donors. It was examined whether the expression was specifically localized to alveolar epithelial cells or/and mesenchymal cell type in the human lung (Figure 4.3. and 4.4.). 
A

Donor

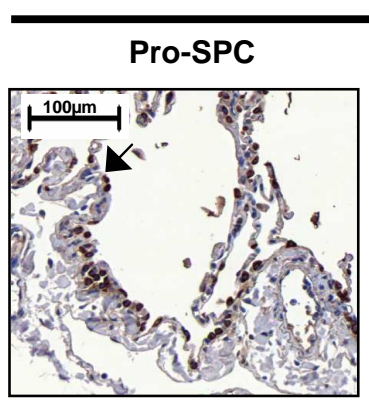

NICD1

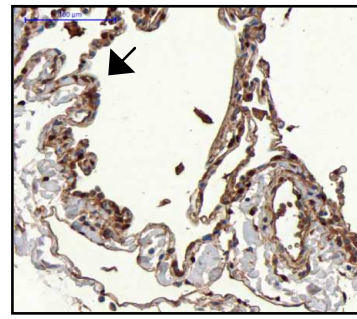

IPF

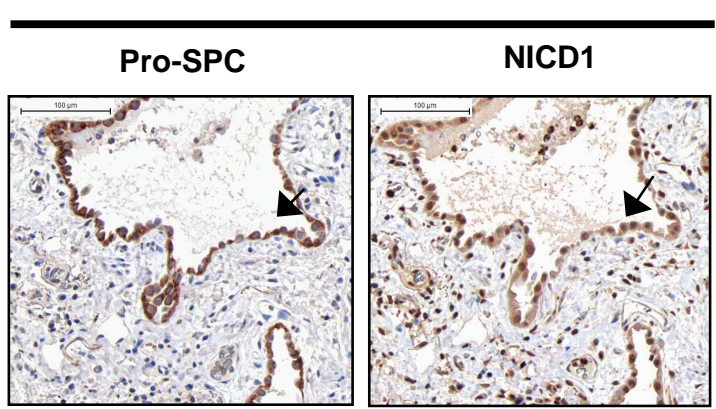

\section{B}

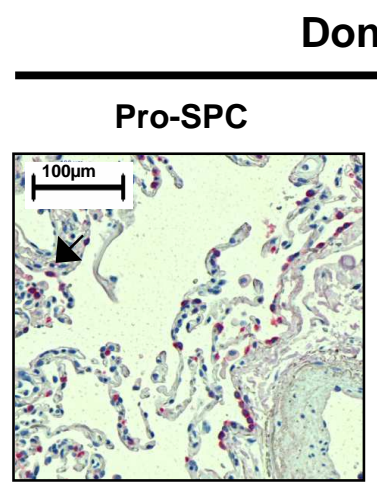

Donor

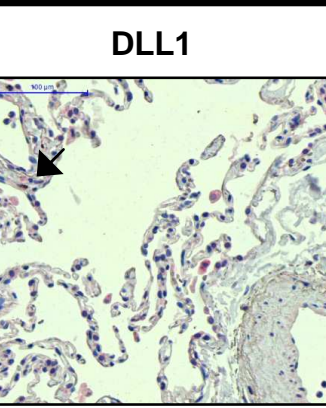

IPF

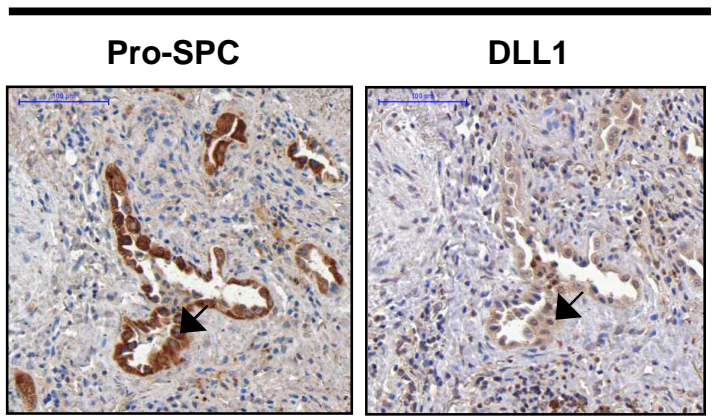

Figure 4.3. Expression of NICD1 and DLL1 in AECII in lungs from organ donors and IPF patients. Immunohistochemical staining of NICD1 (A) and DLL1 (B) in paraffin-embedded, serial lung sections obtained from organ donors and IPF patients. Pro-SPC was used as a marker of AECII cells. The pictures are representative of at least five independent experiments. Bar size is indicated. 
A

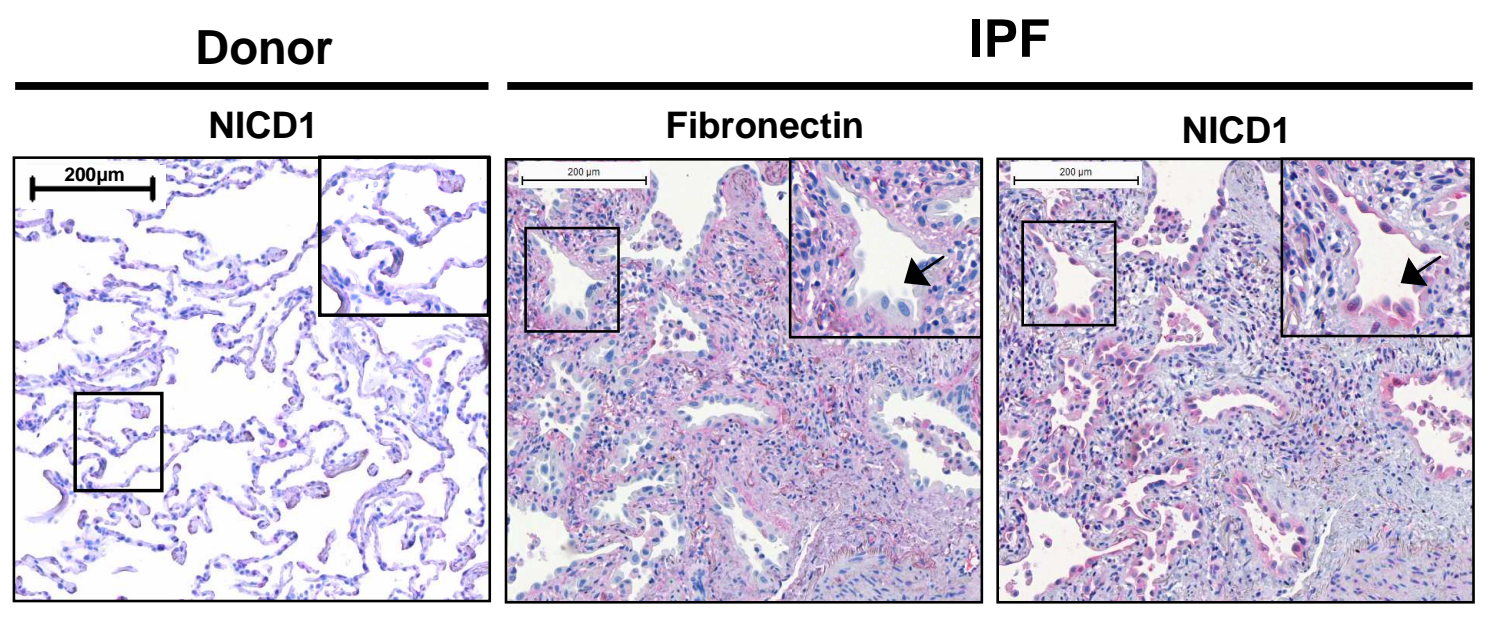

\section{B}

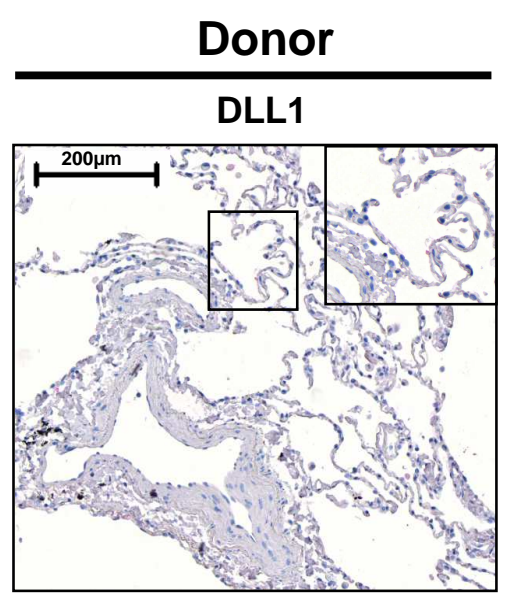

IPF

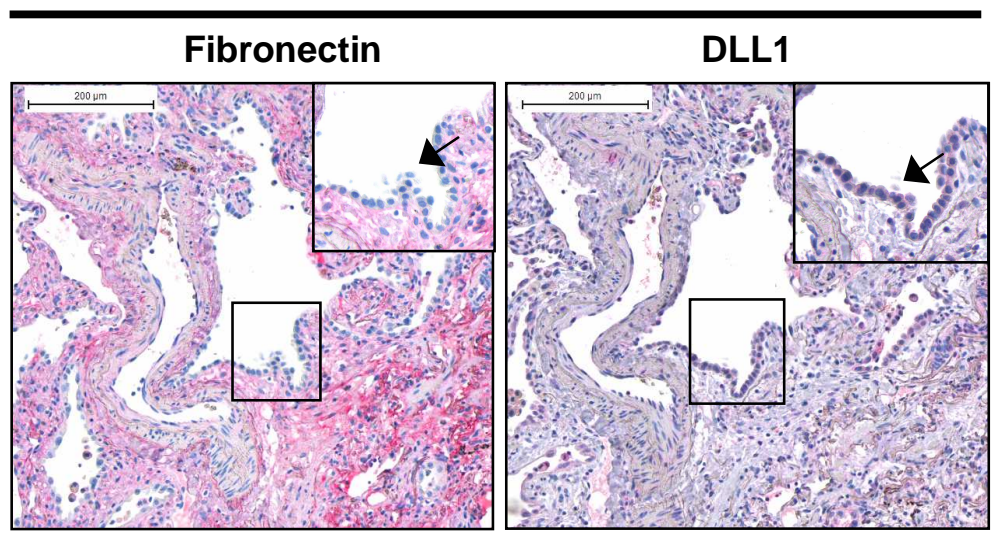

Figure 4.4. Absence of NICD1 and DLL1 in mesenchymal cells in lungs of organ donors and IPF patients.

Immunohistochemical staining of NICD1 (A) and DLL1 (B) in paraffin-embedded lung sections obtained from donors and IPF patients. Fibronectin was used as a mesenchymal cell marker. The pictures are representative of at least three independent experiments. Bar size is indicated.

As shown in Figure 4.3. and 4.4. the expression of NICD1 and DLL1 was increased in IPF sections compared to donor tissue. The strongest immunoreactivity of the NICD1 receptor was observed in alveolar epithelial type 2 cells (AECII) but expression in other compartments (e.g. myofibroblasts, mucus cells) can not be excluded on the basis of the experiments conducted in this study. The specific signal of DLL1 protein on immunohistochemistry was observed almost exclusively in AECII. To verify if expression of NICD1 and DLL1 can be found in the same group of AECII in the fibrotic lung, immunohistochemistry on the serial sections was performed (Figure 4.5.). 


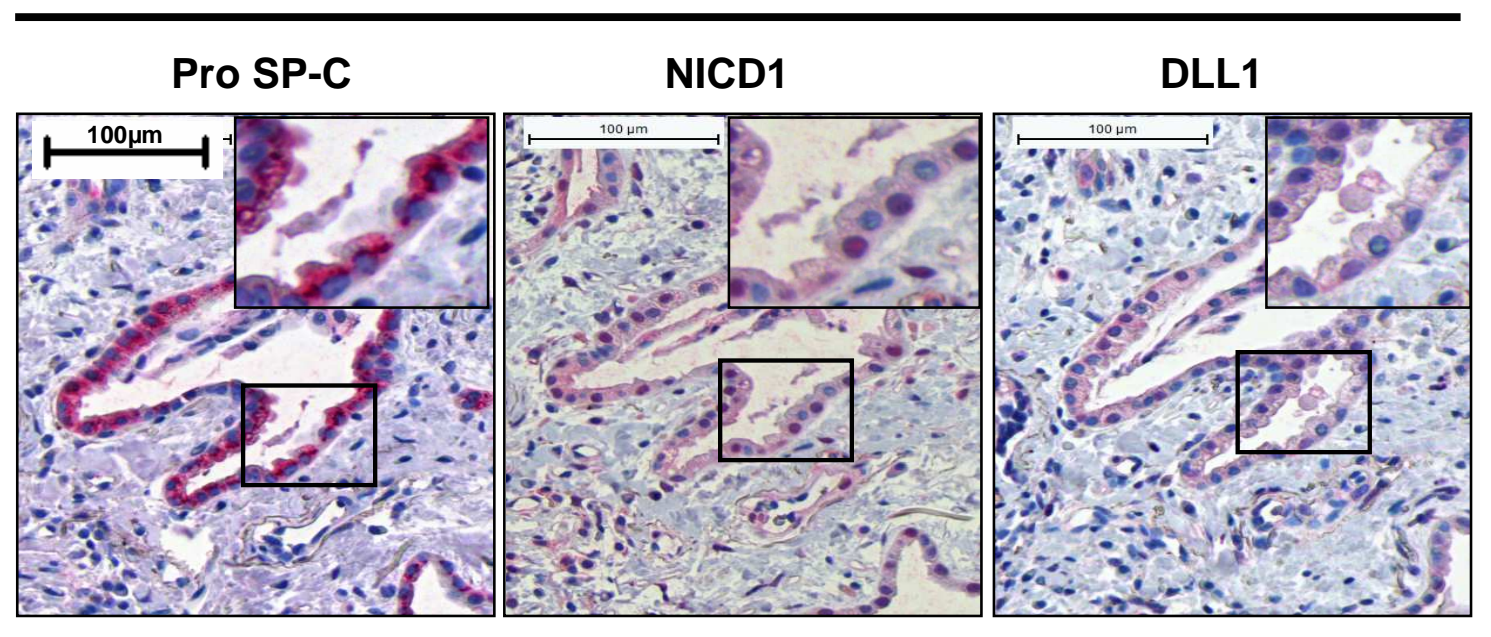

Figure 4.5. Expression and colocalization of NICD1 and DLL1 in the same population of AECII in lung tissue of IPF patients.

Immunohistochemical staining of NICD1, DLL1 and Pro SP-C, as a marker of AECII, in paraffinembedded lung serial sections obtained from IPF patients. The pictures are representative of at least five independent experiments. Bar size is indicated.

As shown in Figure 4.5. NICD1 and DLL1 are expressed in the same population of AECII cells in the fibrotic lung. It can also be noticed, that the activated Notch1 receptor is not localized in nuclei of all AECII and that the DLL1 ligand is localized not only in cytoplasm but also in the nucleus.

\subsubsection{Expression analysis of the Notch target gene HES1}

To further investigate not only the changes in the levels of Notch receptors and ligands in human lungs, but also the activation of this pathway, expression analysis of one of the Notch target genes, Hes1 was performed. The proteins were isolated from human lung homogenates of transplanted IPF patients and organ donors. The protein level of the Notch target gene Hes1 was determined by Western blot (Figure 4.6.). As expected, the protein level of Hes 1 was significantly elevated in fibrotic samples. The expression of this protein in AECII was also confirmed in the distal lung epithelium in the human lung, as determined by IHC (Figure 4.7.). 
A

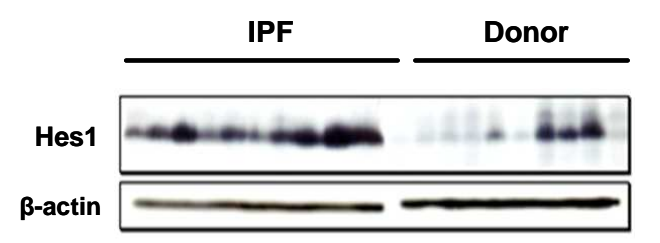

B

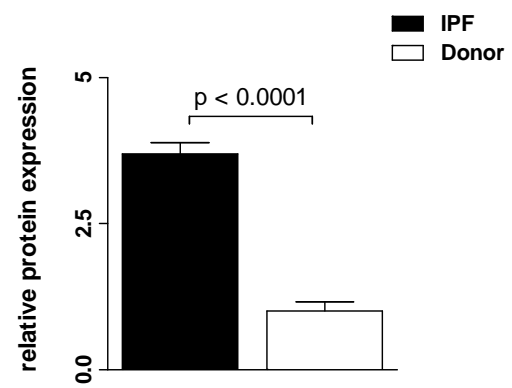

Figure 4.6. Expression analysis of Hes1 in lung homogenates of organ donors and IPF patients. (A) Hes1 expression was analyzed by Western blot in lung homogenates from organ donors and IPF patients. $\beta$-actin served as a loading control (B) Densitometry analysis of the Hes1 protein expression level, normalized to control. All values are given as mean \pm SEM $(n \geq 6)$. Statistical significance was assured by Student's t-test. Significance levels are indicated.

Donor

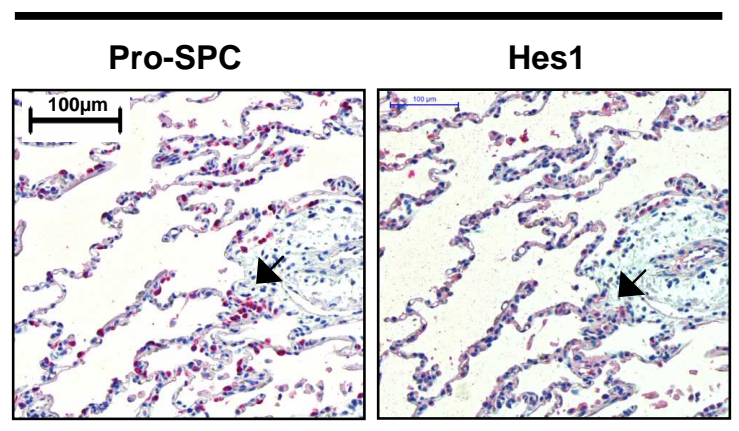

IPF

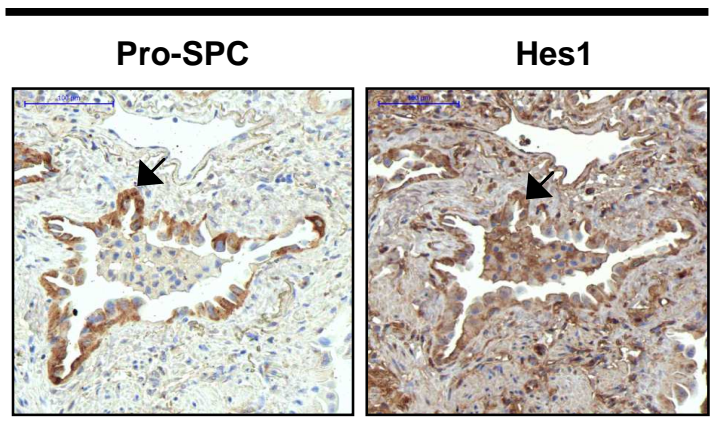

Figure 4.7. Expression of Hes1 in AECII in lungs of organ donors and IPF patients.

Immunohistochemical staining of Hes1 in paraffin-embedded lung sections obtained from donors and IPF patients. Pro-SPC was used as an AECII marker. The pictures are representative of at least three independent experiments. Bar size is indicated.

\subsection{Analysis of the Notch signaling pathway elements in an experimental model of pulmonary fibrosis}

\subsubsection{Expression of Notch signaling pathway elements in bleomycin- induced pulmonary fibrosis}

To find out if the results obtained in human IPF lungs can be reproduced in an animal model of lung fibrosis, the mRNA and protein expression of Notch receptors and ligands was analyzed in the lung homogenates of bleomycin- challenged mice. No significant changes in the mRNA expression of Notch pathway elements were observed 
with the exception of the Notch1 receptor at day 14 and day 28 and the Notch3 receptor at day 21 (post bleomycin application), which were found to be significantly decreased in lung homogenates of control vs. bleomycin- challenged mice (Figure 4.8.A). Also, mRNA of such ligands as Deltal (Dll1) and Jagged2 were significantly decreased at day 14 and day 21 (post bleomycin application), respectively (Figure 4.9.A).

In addition, it was confirmed on the protein level that expression of NICD1 was significantly upregulated from day 7 until day 21 post bleomycin (Figure 4.8.B and C). In case of Dll1 ligand immunoblotting showed a similar upregulation at day 21 and 28 post bleomycin (Figure 4.9.B and C). Additionally, downregulation of the intracellular domain of Notch3 receptor and ligand Delta4 (D114) was observed at later time points (days 21 and 28) (Figure 4.9.B and C). 
A

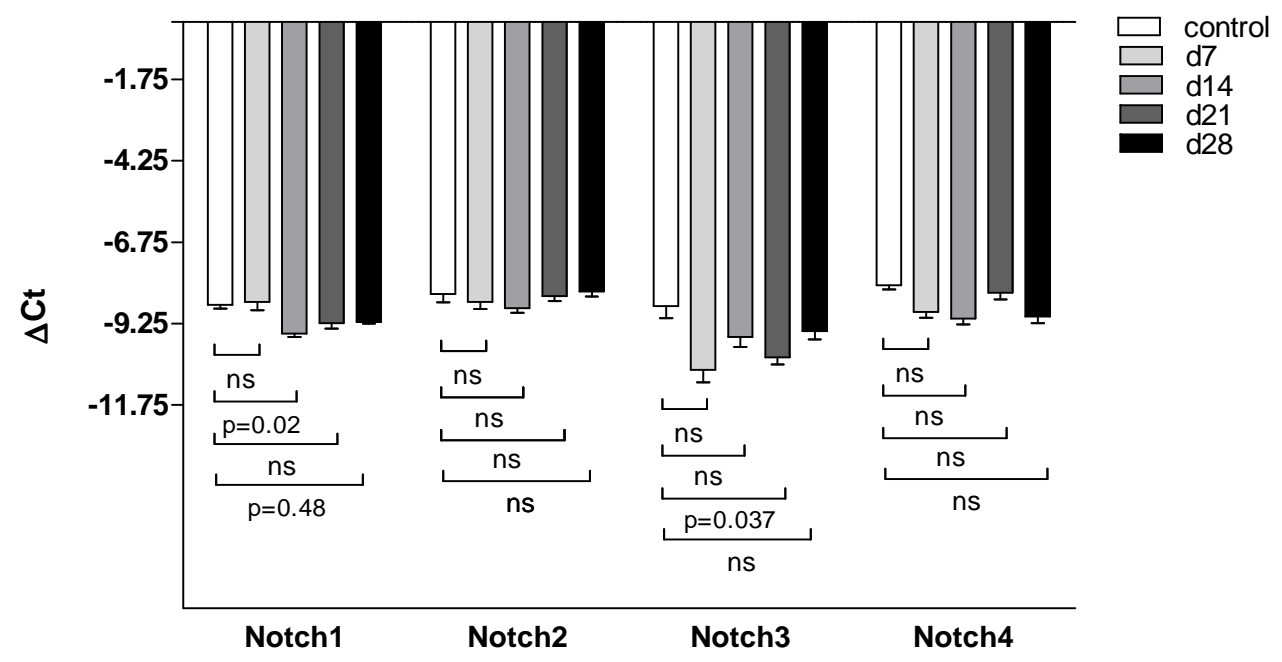

B

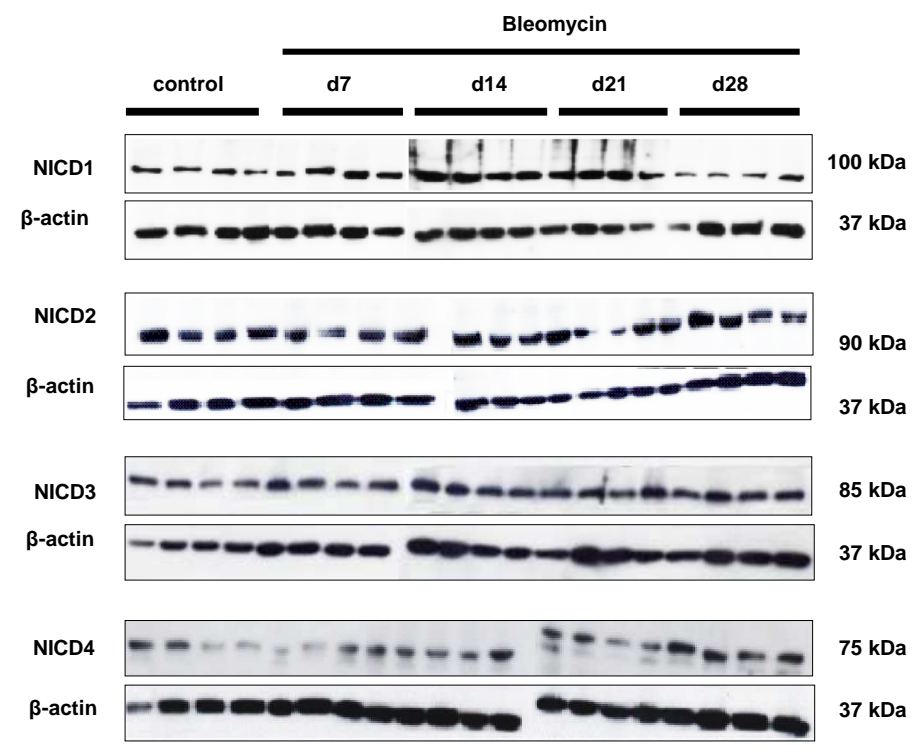



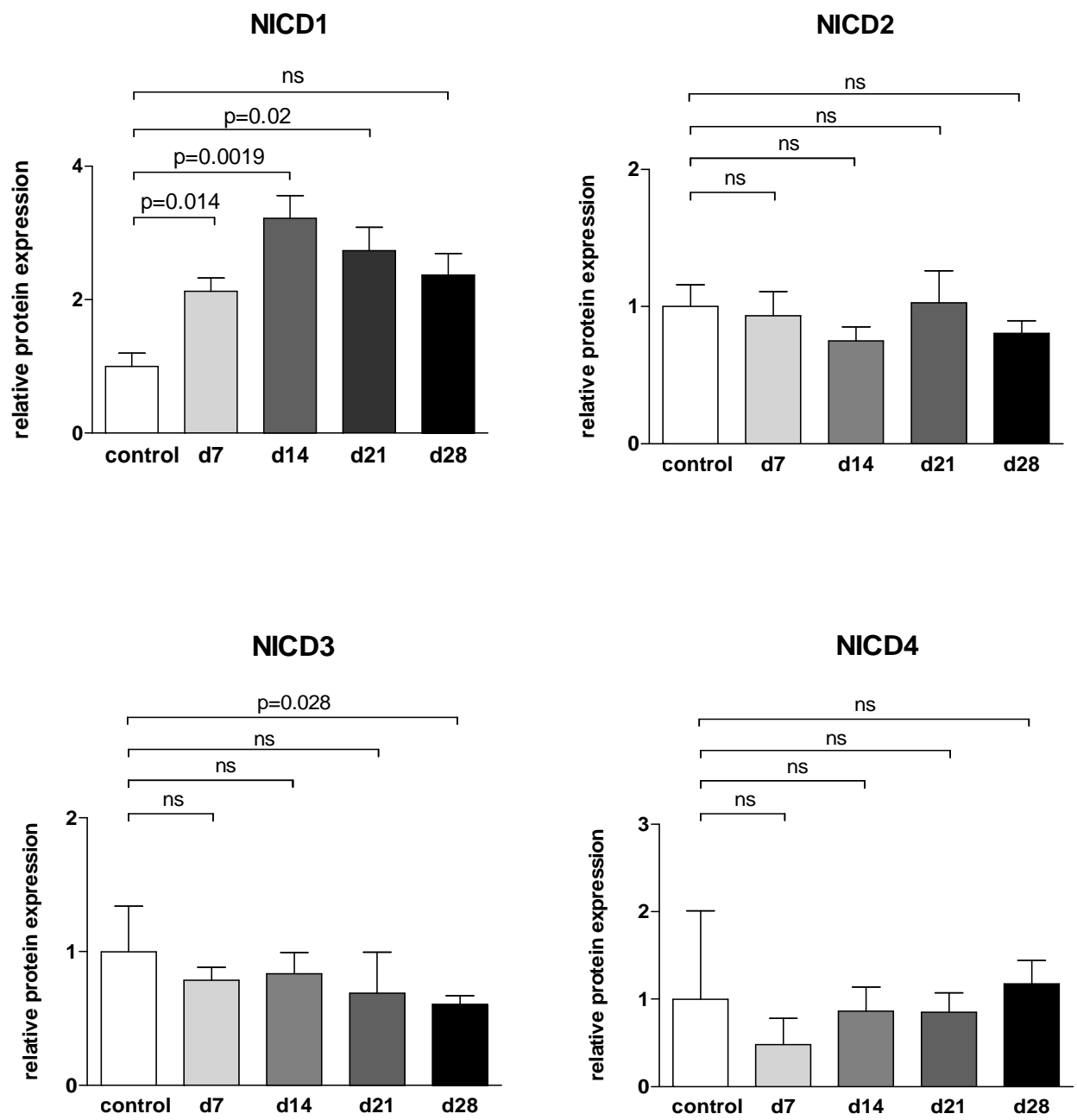

Figure 4.8. Expression analysis of Notch receptors in lung homogenates of control and bleomycinchallenged mice.

(A) Real-time PCR analysis of Notch receptors in lung homogenates from organs from control and bleomycin-challenged mice. Given is the fold-increase in mRNA normalized to $\beta$-actin expression. (B) Notch receptor expression was analyzed by Western blot in lung homogenates from control and bleomycin-challenged mice. $\beta$-actin served as a loading control. (C) Densitometric analysis of Notch receptors, normalized to control. All values are given as mean \pm SEM $(n \geq 4)$.

Statistical significance was assured by Student's t-test. Significance levels are indicated. 
A

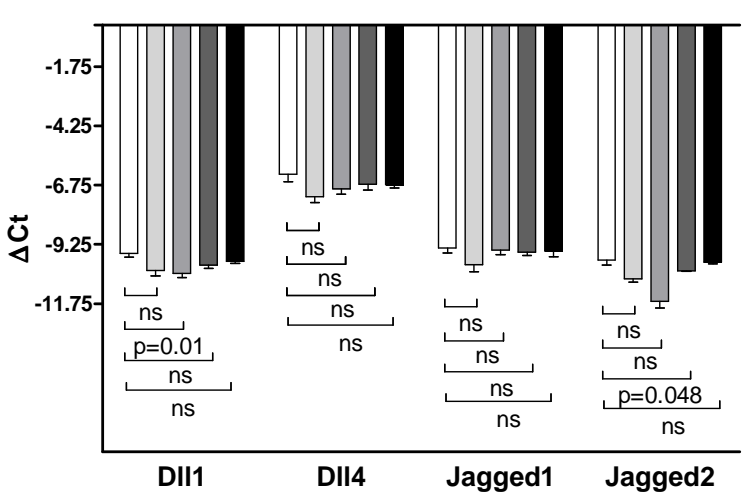

C

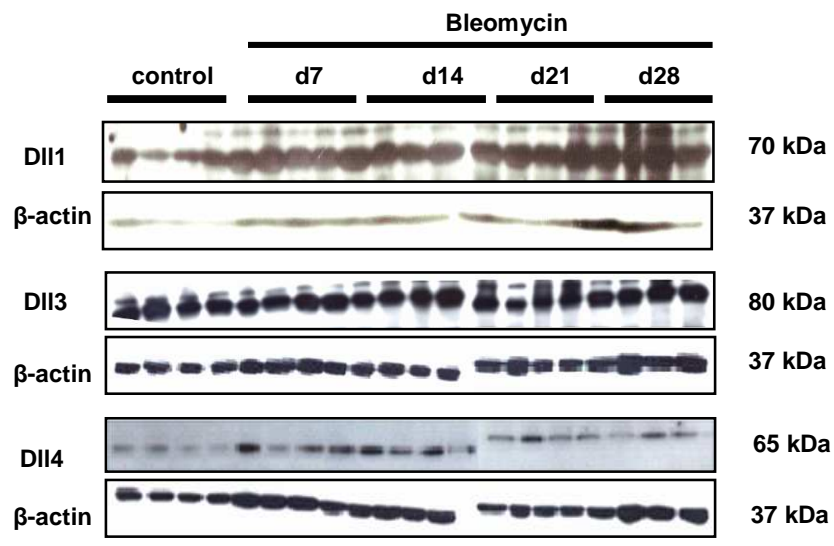

B
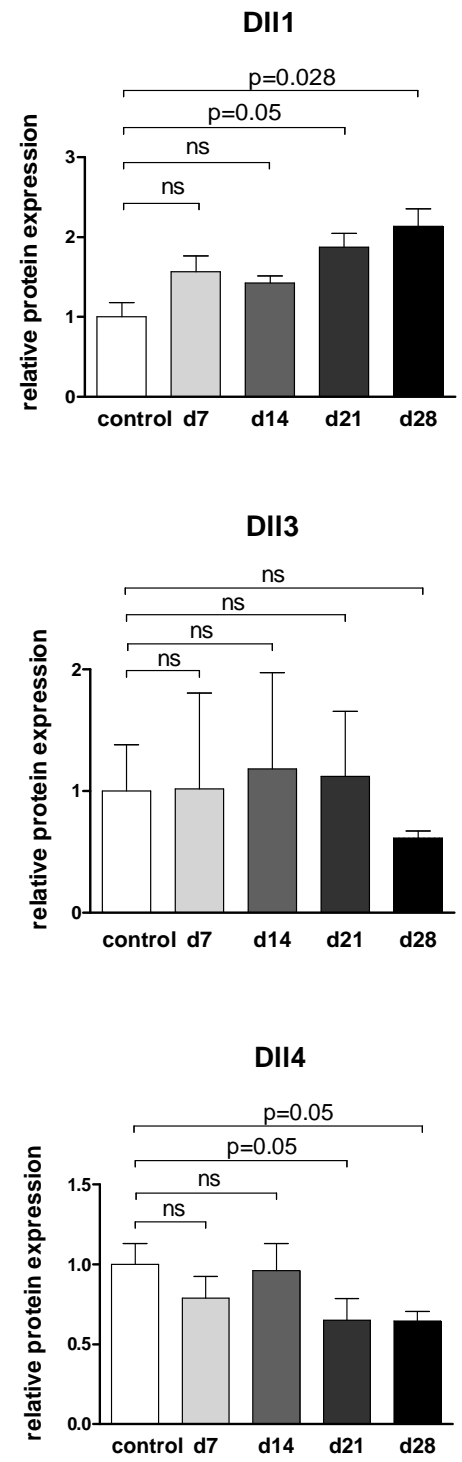

Figure 4.9. Expression analysis of Notch ligands in lungs homogenates of control and bleomycinchallenged mice.

(A) Real-time PCR analysis of Notch ligands in lung homogenates from organs from control and bleomycin-challenged mice. Given is the fold-increase in mRNA normalized to $\beta$-actin expression. (B) Notch ligand expression was analyzed by Western blot in lung homogenates from control and bleomycin-challenged mice. $\beta$-actin served as a loading control. (C) Densitometric analysis of Notch ligands, normalized to control. All values are given as mean $\pm \operatorname{SEM}(n \geq 4)$.

Statistical significance was assured by Student's t-test. Significance levels are indicated. 


\subsubsection{NICD1 colocalization in the lungs of control and bleomycin- treated mice}

Immunohistochemistry confirmed a strong expression of NICD1 in bleomycininjured lungs at day 14 , compared to the weak signal observed in the lungs of saline treated mice (Figure 4.10.). By using serial sections, stained with the AECII specific marker pro SP-C, activated Notch1 was found to be almost exclusively colocalized in alveolar epithelial type II cells.
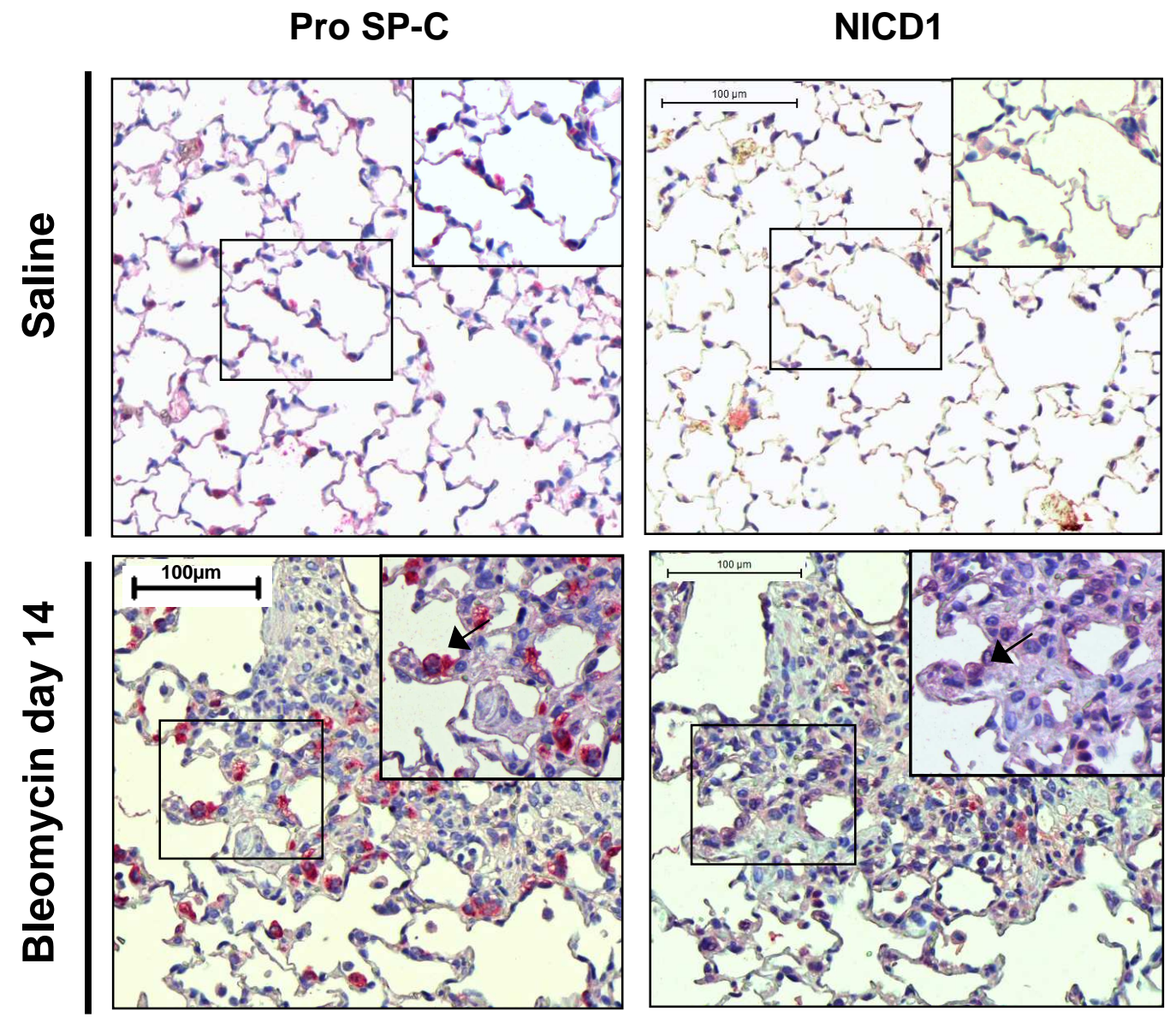

Figure 4.10. Expression and colocalization of the NICD1 receptor in AECII in the lungs of control and bleomycin-treated mice.

Immunohistochemical staining of NICD1 in paraffin-embedded lung sections obtained from saline and bleomycin-treated mice. The pictures are representative of at least four independent experiments. Bar size is indicated. 


\subsection{Influence of Notch signaling on epithelial proliferation}

Notch1 has been known to play a major role in the proliferation of normal rat kidney tubule epithelium (NRK) cells. It has been proven, using in vivo studies, that genetic overexpression of Notch1 likely plays a role in tubulointerstitial fibrosis (TIF) development via controlling cell proliferation (5). As shown in 4.3. and 4.10. NICD1 is mostly expressed by AECII in IPF and in the bleomycin mouse model of pulmonary fibrosis. Therefore, primary epithelial mouse cells (AECII) and an alveolar epithelial cell line (MLE 12) were used for further studies, addressing the role of Notch on lung epithelial proliferation.

\subsubsection{Influence of NICD1 expression on proliferation of MLE 12 cells}

To test whether NICD1 has a functional role in alveolar epithelial cells, the cDNA encoding exclusively the intracellular domain of Notch1 was cloned into the mammalian expression vector pIRES-DsRed2. 24h post transfection, MLE 12 cells showed a higher expression of NICD1 as compared to a control (empty) vector (Figure 4.11.A.). As expected, the mRNA expression levels of Notch target genes Hes1, Heyl and Hey 2 were significantly upregulated after 24h of NICD1 overexpression in MLE 12 cells (Figure 4.11. B.). 
A

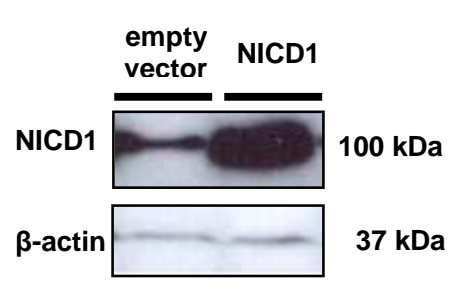

B

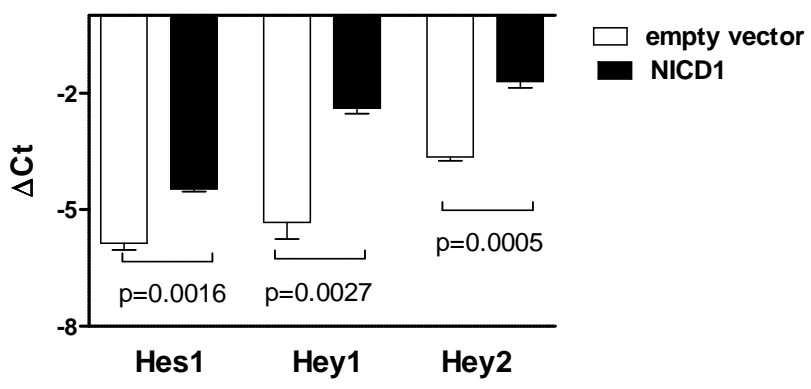

Figure 4.11. Overexpression of the NICD1 receptor in MLE 12 cells.

(A) Western blot of MLE 12 cells overexpressing the NICD1 receptor, 24h after transfection and compared to an empty vector. B-actin served as a loading control (B) Real-time PCR analysis of Notch downstream genes: Hes1, Heyl, Hey2 in MLE 12 cells, 24h after transfection with the NICD1 overexpressing vector compared to an empty vector. Given is the fold-increase in mRNA expression in response to transfection with an empty vector normalized for $\beta$-actin expression) vs. NICD1. All values are given as mean \pm SEM $(n=3)$.

Statistical significance was assured by the Student's t-test. Significance levels are indicated.

To measure the level of proliferation of epithelial cells in vitro, the $\left[{ }^{3} \mathrm{H}\right]$-thymidine incorporation method was used. Increased cDNA synthesis, which indicated raised proliferation following 30h of Notch1 intracellular domain expression, was confirmed in MLE 12 cells (Figure 4.12.A.). Moreover, in Notch-expressing cells, increased protein expression of proliferating cell nuclear antigen (PCNA) was observed (Figure 4.12.B and C), which was consistent with Notch1-induced proliferation. 
A

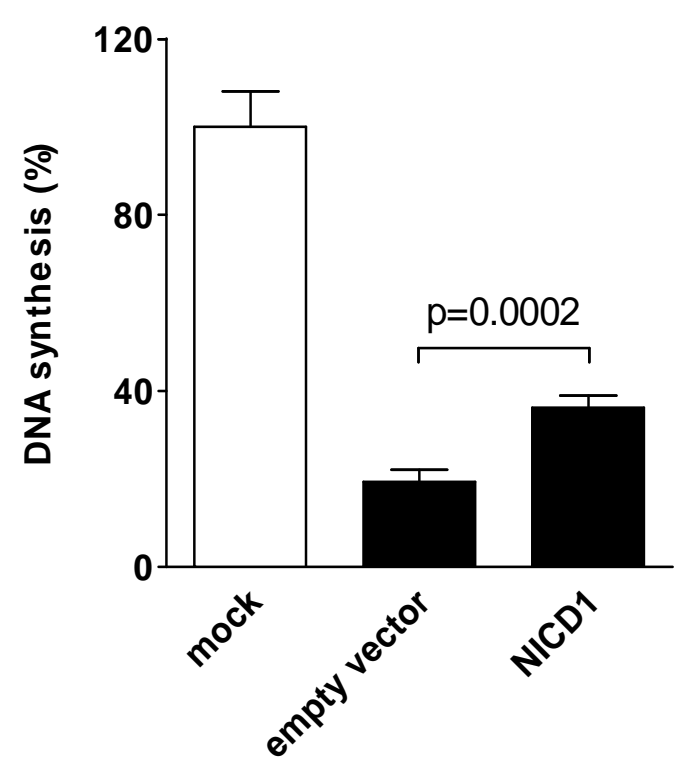

B

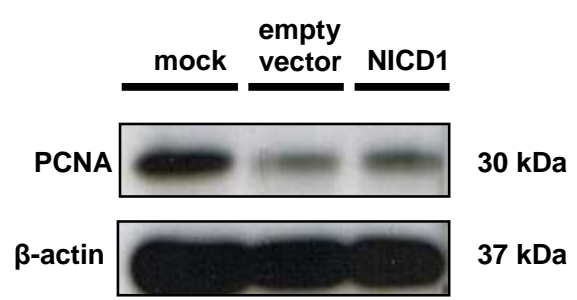

C

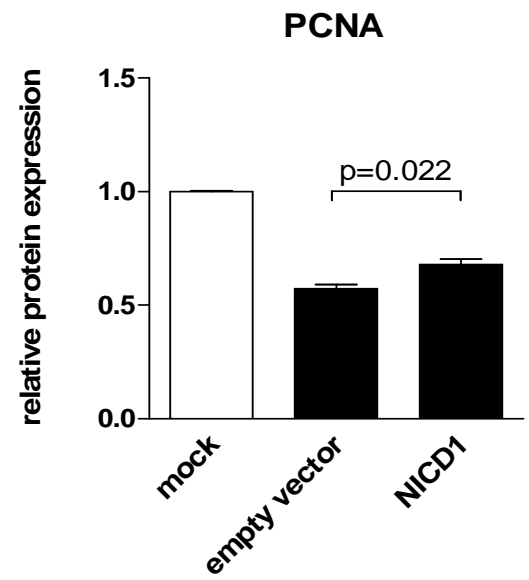

Figure 4.12. Cell proliferation in Notch-expressing MLE 12 cells.

(A) $\left[{ }^{3} \mathrm{H}\right]$-Thymidine incorporation measured in MLE 12 cells following 30h of Notch1 expression. All values are given as mean \pm SEM $(n \geq 10)$ and are normalized to mock transfection $(100 \%)$ as a control. (B) PCNA expression in MLE 12 cells following 30h of Notch expression. B-actin served as a loading control. (C) Densitometric analysis of the PCNA protein expression level, normalized control. All values are given as mean $\pm \operatorname{SEM}(n=3)$.

Statistical significance was assured by Student's t-test. Significance levels are indicated.

\subsubsection{Influence of Notch signaling inhibition on epithelial proliferation and survival}

Based on the previous observations, it was asked if blockage of the Notch pathway could influence the level of proliferation in mouse epithelial cells in vitro. To answer this question a knock-down of POFUT1 and/or chemical inhibition of the Notch pathway by DAPT were employed. 


\subsubsection{Inhibition of Notch signaling in the mouse epithelial cell line} (MLE 12)

The MLE 12 cell line was transfected with siRNA directed against murine POFUT1. The knockdown efficiency was analyzed by Western blot (Figure 4.13.). The protein level of the activated Notch1 receptor was significantly downregulated $(\sim 70 \%)$ $72 \mathrm{~h}$ after transfection with POFUT1 siRNA oligonucleotides.

A

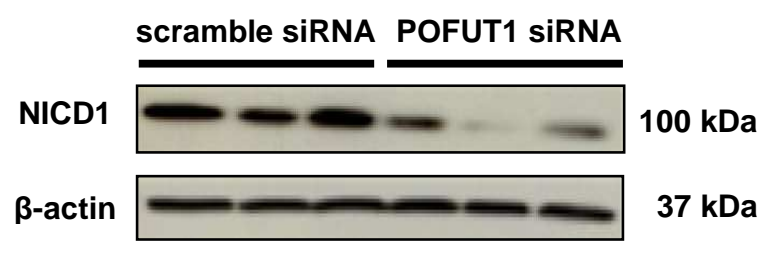

B

NICD1

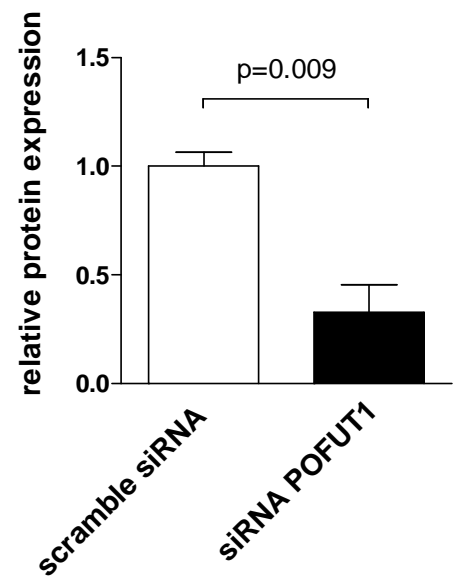

Figure 4.13. Analysis of siRNA-mediated knockdown of POFUT1.

(A) The MLE 12 cells were transfected with the siRNA specific to the mouse POFUT1 mRNA for 72h and the protein levels were analyzed by Western blot. ß-actin, served as a loading control. (B) Densitometric analysis of NICD1 protein level expression, normalized to control. All values are given as mean $\pm \operatorname{SEM}(n=3)$. Statistical significance was assured by Student's t-test. Significance levels are indicated.

MLE 12 cells were also treated with DAPT, an inhibitor of Notch activation. The reduction in cleaved Notch1 receptor (which is an activated form) was analyzed by Western blot (Figure 4.14.A and B). A significant downregulation ( 50\%) of NICD1 protein was observed after 54h. In parallel, the mRNA level of downstream gene Hes 1 was also found to be decreased (Figure 4.14.C.). 
A

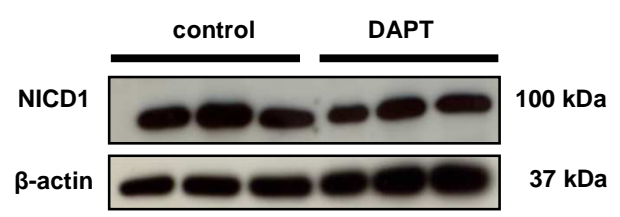

B

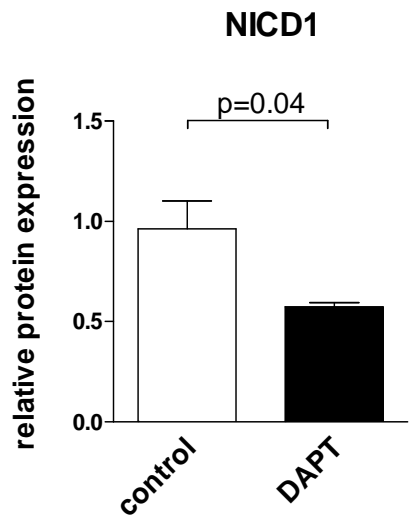

$\mathbf{C}$

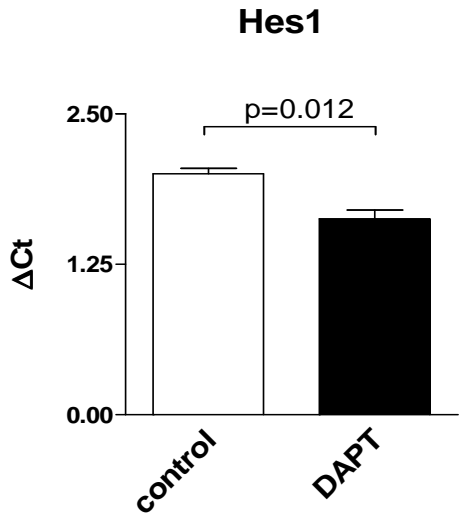

Figure 4.14. Analysis of chemical NICD1 inhibition in MLE 12 cells.

(A) MLE 12 cells were stimulated with DAPT for 54h and the protein levels were analyzed by Western blot. (B) Densitometric analysis of NICD1 protein level expression. All values are given as mean \pm SEM $(\mathrm{n}=3)$ and are normalized to $\mathrm{B}$-actin, served as a loading control. (C) Real time PCR analysis of Notch downstream genes Hesl, 54h after inhibition with DAPT compared to DMSO (dimethyl sulfoxide) control. Given is mean \pm SEM ( $n=3)$ as a fold-increase in mRNA expression in control (normalized to $\beta$ actin expression) versus values obtained from DAPT treated cells.

Statistical significance was assured by Student's t-test. Significance levels are indicated.

Following this approach, decreased cell proliferation by $\left[{ }^{3} \mathrm{H}\right]$-thymidine incorporation in MLE 12 cells was observed upon both, transfection with the siRNA specific for murine POFUT1 as well as stimulation with the Notch inhibitor DAPT (Figure 4.15.A and B). Additionally, after POFUT1 siRNA knockdown in MLE 12 cells, immunofluorescence staining showed lack of a Ki67, a proliferation marker, in parallel to a lack of NICD1 expression (Figure 4.15.C.). 
A

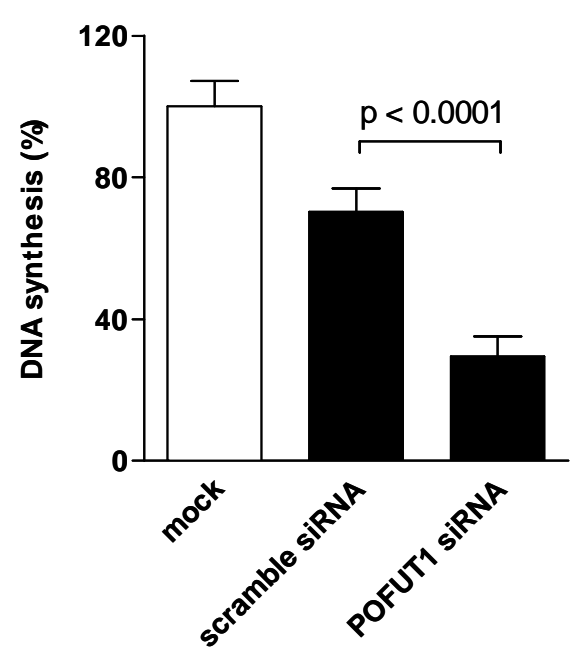

C

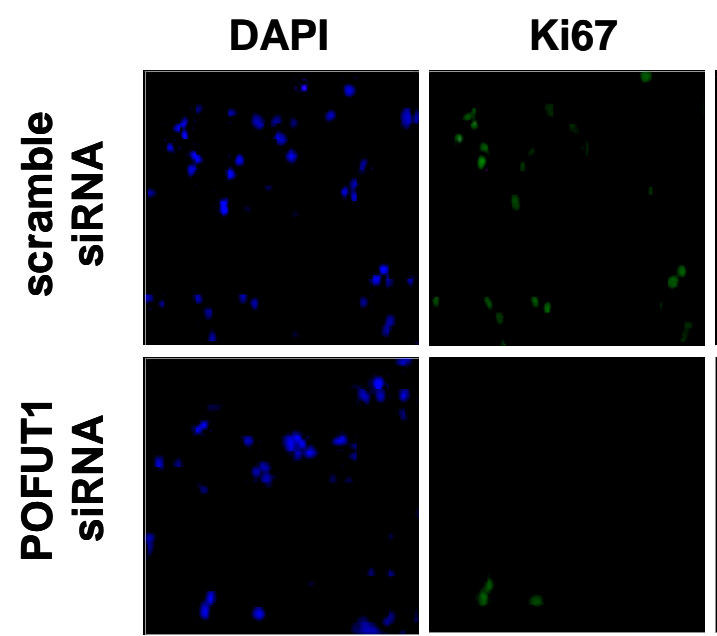

B

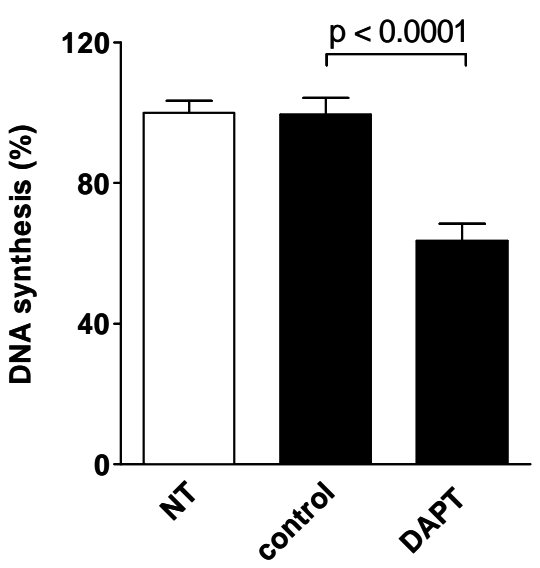

NICD1
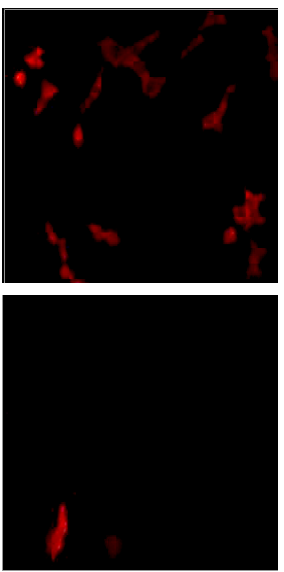

Merge
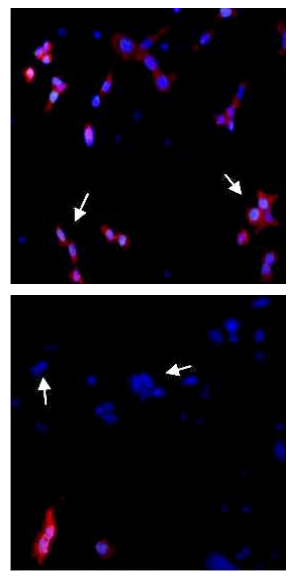

Figure 4.15. Proliferation of MLE 12 cells upon inhibition of Notch signaling.

(A) $\left[{ }^{3} \mathrm{H}\right]$-Thymidine incorporation in MLE 12 cells $72 \mathrm{~h}$ after POFUT1 knockdown by siRNA. (B) $\left[{ }^{3} \mathrm{H}\right]$-Thymidine incorporation in MLE 12 cells following 54h chemical Notch inhibition by DAPT $(5 \mu \mathrm{M})$. All values are given as mean \pm SEM $(\mathrm{n} \geq 10)$ and are normalized to mock as a control $(100 \%)$. (C) Colocalization of NICD1 and Ki67 in POFUT1 siRNA knockdown MLE 12 cells, showed by immunofluorescence

Statistical significance was assured by Student's t-test. Significance levels are indicated.

This observation raised the question if Notch cleavage inhibition in primary mouse AECII would similarly affect proliferation. 


\subsubsection{Influence of Notch signaling on proliferation of primary mouse} AECII

To confirm the data obtained with the MLE 12 cell line, primary AECII were used to investigate the influence of the Notch pathway on proliferation. Freshly isolated primary AECII from saline and bleomycin-treated mice (day 14 post bleomycin application) showed a high purity $(>90 \%)$, as assessed by immunofluorescence for epithelial (Pro SP-C, E-cadherin) and mesenchymal (fibronectin and $\alpha$-smooth muscle actin) markers (Figure 4.16.).
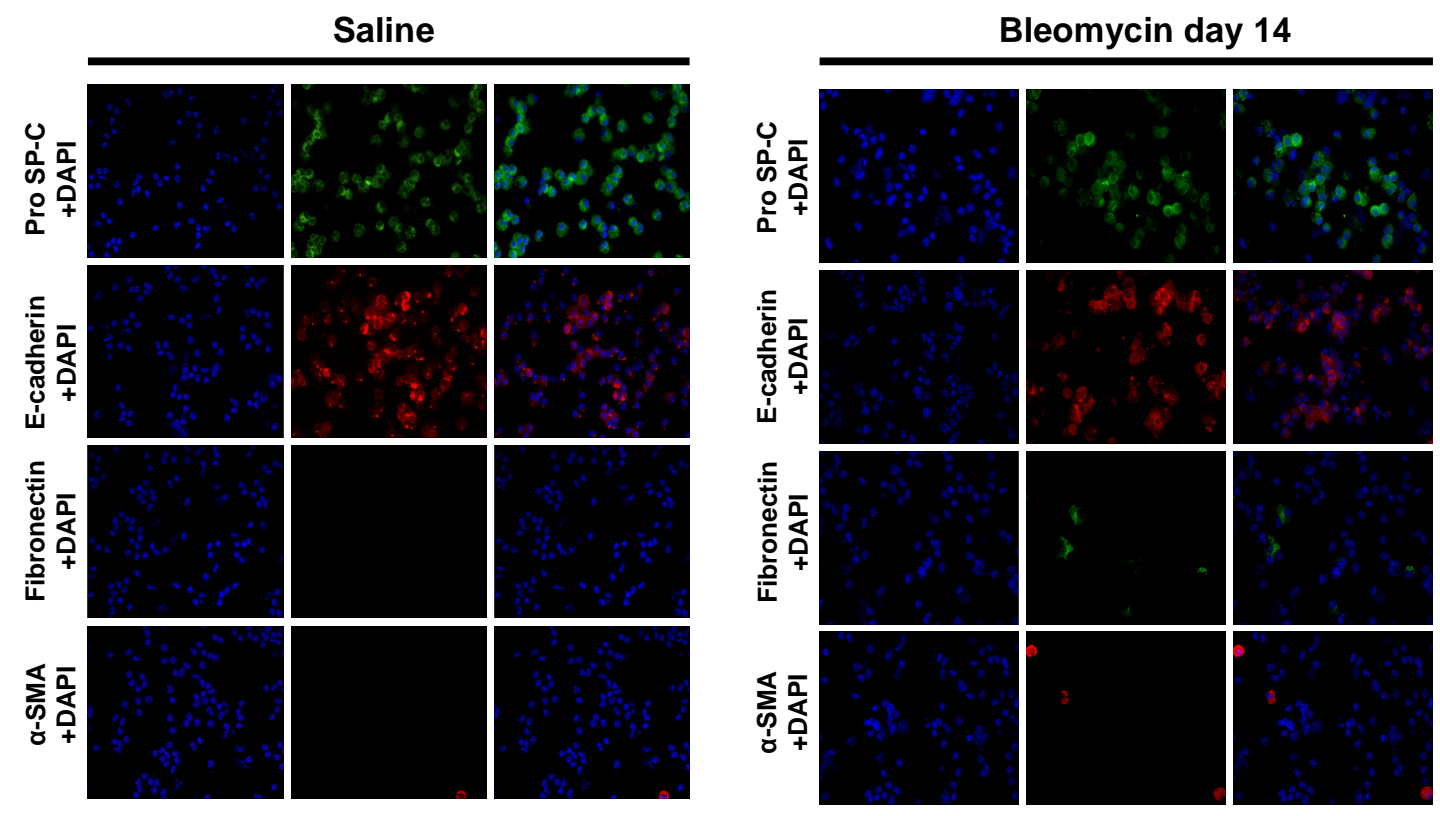

Figure 4.16. Purity of primary AECII.

Pro SP-C, E-Cadherin, fibronectin and $\alpha$-SMA were all stained by immunofluorescence on cytospinspreparation from freshly isolated primary AECII from saline and bleomycin-treated mice (day 14). Cell nuclei were visualized with DAPI (blue). Original magnification is 40x.

Because of the resistance of primary AECII to transfection, the chemical inhibitor DAPT was used to reduce the level of activated Notch1. Proliferation was measured by $\left[{ }^{3} \mathrm{H}\right]$-thymidine incorporation analysis. Without any stimulation, but on reduced FCS (1\%) level, an increased proliferation of AECII from bleomycin (day 14) treated animals was evident: AECII from bleomycin-treated mice showed more DNA synthesis than those isolated from saline treated mice (Figure 4.17.A). Inhibition of Notch by DAPT resulted in decreased DNA synthesis only in cells isolated from bleomycin- 
challenged animals as compared to cells isolated from saline treated mice (Figure 4.17.B. and C).

A

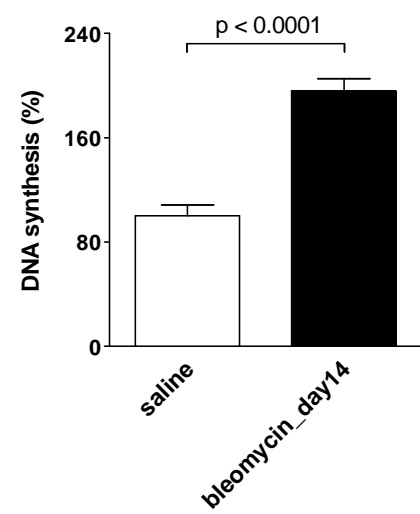

B

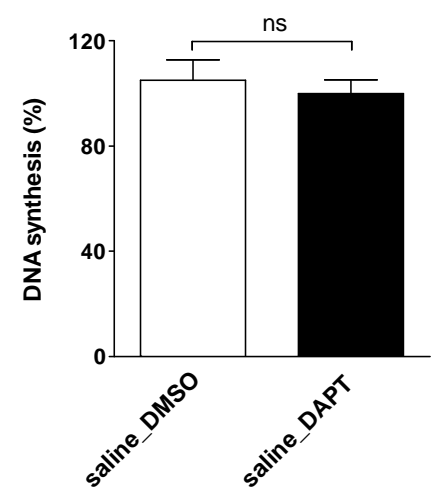

C

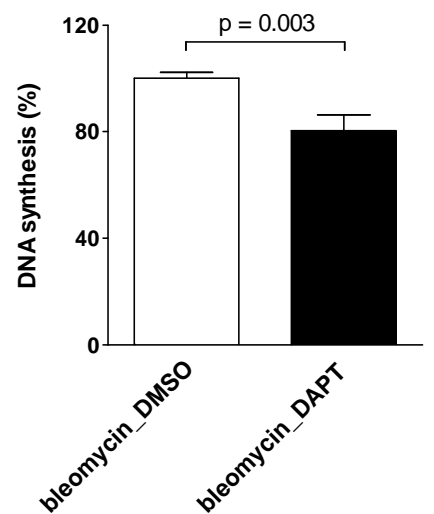

Figure 4.17. Proliferation of AECII cells isolated from saline and bleomycin (day 14) treated mice. $\left[{ }^{3} \mathrm{H}\right]$-Thymidine incorporation in AECII isolated from saline (A, B) and bleomycin (A, C) treated mice. Cells were plated on plastic and were grown in serum-reduced medium for $40 \mathrm{~h}$ in absence of any stimulation or upon incubation with DAPT $(10 \mu \mathrm{M})$ for $24 \mathrm{~h}$ or DMSO $(0,5 \%)$ as a control (B and C). All values are given as mean \pm SEM $(n \geq 10)$ and are normalized to cells isolated from saline treated mice $(100 \%)$, cells isolated from saline treated mice incubated with DMSO (100\%) or cells isolated from bleomycin-treated mice treated with DMSO (100\%), respectively.

Statistical significance was assured by Student's t-test. Significance levels are indicated.

\subsubsection{Expression of NICD1 and the proliferation marker in lung tissue of IPF patients}

To evaluate whether NICD1 may also have any influence on proliferation in human samples, imunohistochemistry was performed on IPF sections. As depicted in Figure 4.18., colocalization of the intracellular domain of the Notch1 receptor and the proliferation marker Ki67 was evident in AECII. 

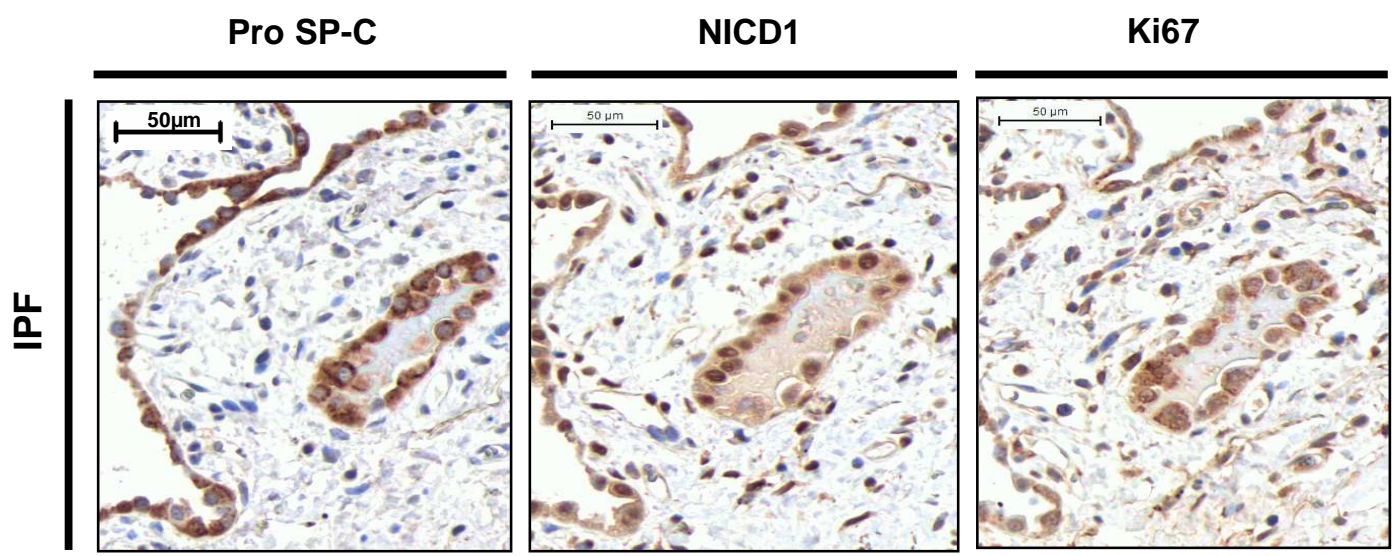

Figure 4.18. Expression and colocalization of NICD1 and Ki67 in AECII in lung tissue of IPF patients.

Immunohistochemical staining for NICD1, Ki67 and Pro SP-C, as a marker of AECII in paraffinembedded, lung serial sections obtained from IPF patients. The pictures are representative of at least five independent experiments. Bar size is indicated.

\subsection{Influence of Notch signaling on apoptosis in vitro}

\subsubsection{Impact of NICD1 overexpression on apoptosis of MLE 12 cells}

To evaluate the possibility that Notch1 may have an influence on the susceptibility to apoptosis, MLE 12 cells were transfected with the NICD1 encoding plasmid and additionally stimulated with the apoptosis inducer-staurosporine. LDH assay and Western blot for cleaved caspase 3 were performed to quantify the apoptosis response. As shown in Figure 4.19., overexpression of NICD1 per se did not result in apoptosis or necrosis. Moreover, overexpression of the intracellular domain of the Notch1 receptor also did not influence staurosporine-induced apoptosis. 
A

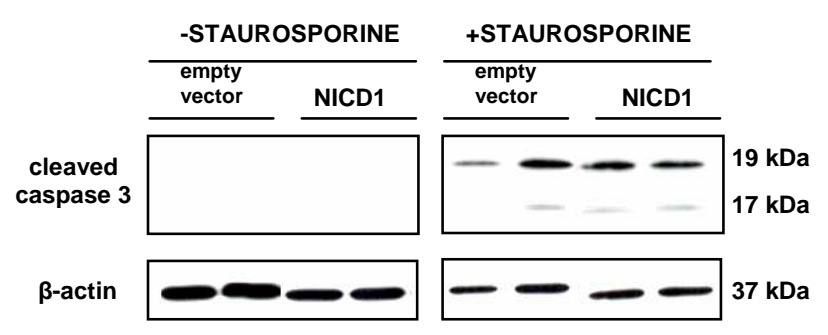

B LDH assay

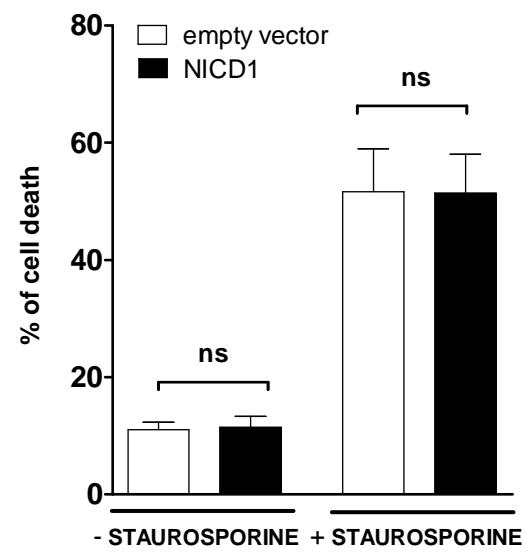

Figure 4.19. Extent of apoptosis of MLE 12 cells in response to NICD1 overexpression and staurosporine treatment.

MLE 12 cells were transfected with an empty vector or a vector encoding the intracellular domain of the mouse Notch1 receptor, incubated for 24h and then treated with staurosporine or DMSO vehicle control. Cleaved caspase 3 was analyzed by Western blot (A). Cell death was quantified by LDH assay (B). All values are given as mean \pm SEM $(n=3)$. Statistical significance was assured by Student's t-test. Significance levels are indicated.

\subsubsection{Impact of impaired Notch signaling on apoptosis of MLE 12 cells}

The data presented in 4.5.1. suggested that Notch1 does not have any influence on cell death. To further confirm those results, LDH assays were performed upon treatment of MLE 12 cells with POFUT1 siRNA or with the Notch inhibitor DAPT (Figure 4.20.A and B). As expected, cell death processes remained unchanged after Notch inhibition alone. Moreover, treatment with POFUT1 siRNA or DAPT inhibitor did not show any significant impact on staurosporine induced cell death. 
A

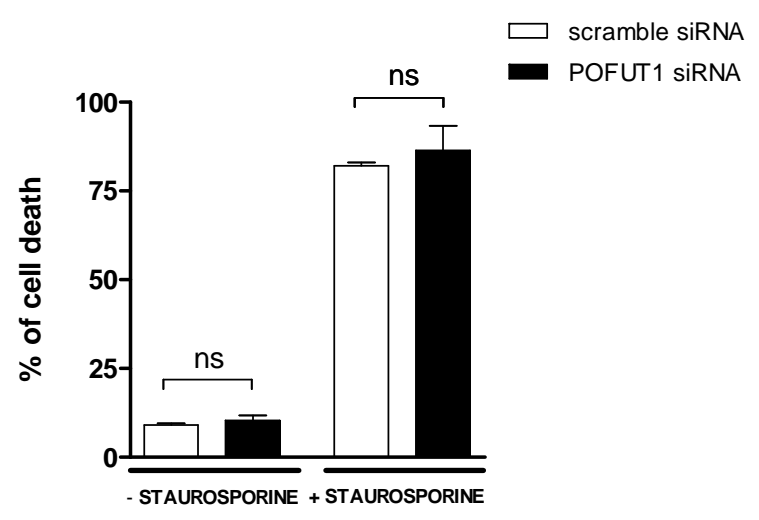

B

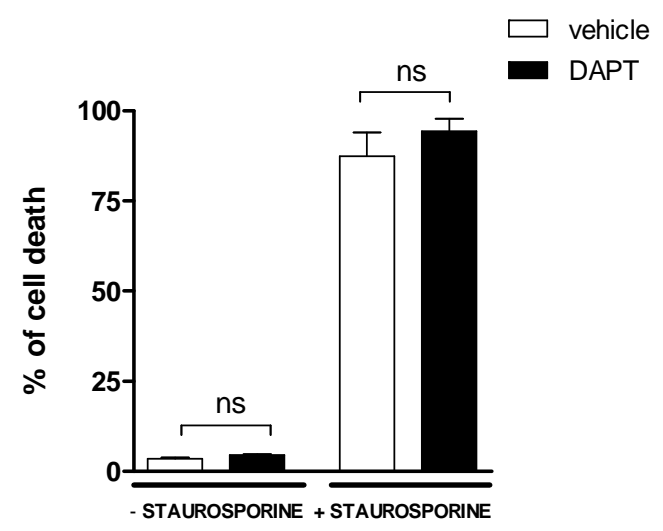

Figure 4.20. Influence of Notch inhibition on cell death of MLE 12 cells.

MLE 12 cells were transfected with POFUT1 siRNA for 72h (A) or stimulated with the Notch inhibitor DAPT for 54h (B), then left untreated or treated with staurosporine. Extent of cell death was analyzed by LDH assay. All values are given as mean \pm SEM $(n=3)$. Statistical significance was assured by Student's t-test. Significance levels are indicated.

\subsection{Downstream signaling of Notch1 in alveolar epithelial cells}

To identify pathways, which may be involved in the Notch - dependent increase in proliferation of mouse alveolar epithelial cells, a genome-wide mRNA microarray analysis of MLE 12 cells overexpressing NICD1 vs. a control vector was performed. Genes exhibiting a greater than two-fold change in expression were considered as being differentially expressed, as described in the Materials and Methods section. For the three predefined timepoints $12 \mathrm{~h}, 24 \mathrm{~h}$ and $48 \mathrm{~h}$ post transfection total number of genes, which were differentially expressed, was 14, 102 or 237, respectively. To analyze specific pathways involved in Notch1-induced proliferation, the Gene Set Enrichment Analysis was used. 12h after NICD1 overexpression, no particular pathway turned out to be differentially regulated. In contrary, prolonged overexpression of Notch1 for $24 \mathrm{~h}$ and $48 \mathrm{~h}$ resulted in a significantly different regulation of several pathways, which are summarized in Table 5. 


\begin{tabular}{|c|c|c|}
\hline $24 \mathrm{~h}$ & $24 h \& 48 h$ & $48 h$ \\
\hline $\begin{array}{c}\text { Antigen processing and } \\
\text { presentation } \\
\text { Atrazine degradation } \\
\text { Cell adhesion molecules } \\
\text { (CAMs) } \\
\text { Cytokine-cytokine receptor } \\
\text { interaction } \\
\text { Huntington's disease } \\
\text { Jak-STAT signaling pathway } \\
\text { Long-term depression } \\
\text { Melanogenesis } \\
\text { Natural killer cell mediated } \\
\text { cytotoxicity } \\
\text { T cell receptor signaling } \\
\text { pathway }\end{array}$ & $\begin{array}{c}\text { Acute myeloid leukemia } \\
\text { Adherens junction } \\
\text { Apoptosis } \\
\text { Axon guidance } \\
\text { Bladder cancer } \\
\text { Cell cycle } \\
\text { Chronic myeloid leukemia } \\
\text { Colorectal cancer } \\
\text { ECM-receptor interaction } \\
\text { Endometrial cancer } \\
\text { ErbB signaling pathway } \\
\text { Focal adhesion } \\
\text { Gap junction } \\
\text { Glioma } \\
\text { GnRH signaling pathway } \\
\text { Insulin signaling pathway } \\
\text { MAPK signaling pathway } \\
\text { Melanoma } \\
\text { mTOR signaling pathway } \\
\text { Pancreatic cancer } \\
\text { Prostate cancer } \\
\text { Regulation of actin cytoskeleton } \\
\text { Small cell lung cancer } \\
\text { TGF-beta signaling pathway } \\
\text { Toll-like receptor signaling } \\
\text { pathway } \\
\text { Type II diabetes mellitus } \\
\text { Ubiquitin mediated proteolysis }\end{array}$ & 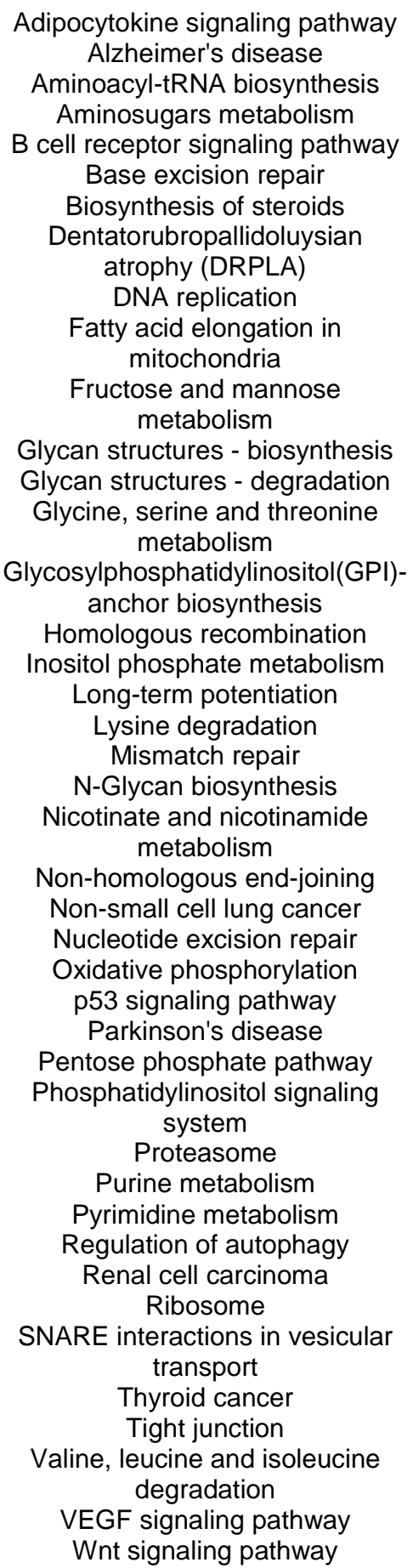 \\
\hline
\end{tabular}

Table 5. Pathway analysis performed with Gene Set Enrichment Analysis.

MLE 12 cells were transfected with NICD1 overexpressing vector for $24 \mathrm{~h}$ and $48 \mathrm{~h}$. Obtained results were compare to cells transfected with an empty control vector. 
One of the pathways that was significantly differently regulated was the mitosisactivated protein kinase (MAPK) pathway. Both the Notch and the MAPK pathways play important roles in many biological processes. Frequently, these two signaling pathways intersect to influence common processes, but depending on cellular context they cooperate or antagonize each other (108-110).

In our microarray experiments data suggested the MAPK pathway differentially regulated $24 \mathrm{~h}$ as well as $48 \mathrm{~h}$ after NICD1 overexpression (Table 5.). To confirm these results, Erk1/2 and Erk5 phosphorylation were analyzed. 48h after NICD1 overexpression, an increase in Erk5 phosphorylation was observed (Figure 4.21.B) in absence of an impact of NICD1 overexpression on phosphorylation of Erk1/2 (p44/42; Figure 4.21.A).

A

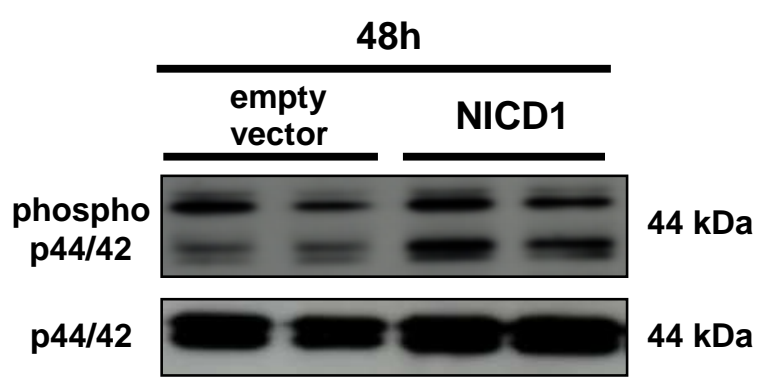

B

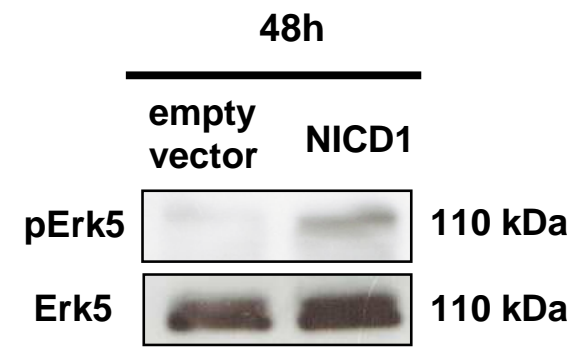

Figure 4.21. Regulation of MAPK pathway elements after NICD1 overexpression in MLE 12. (A) Empty vector or NICD1 overexpression was performed in MLE 12 cells for 48h, followed by analysis of Erk1/2 (phospho p44/42 in A) and Erk5 (pErk5 in B) phosphorylation. B-actin served as a loading control. All the figures are representative of at least two independent experiments. 


\section{Discussion}

\subsection{Reactivation of developmental pathways in lung fibrosis}

IPF is a chronic lung disease of unknown etiology (1). It affects approximately 500000 people in the USA and Europe (111). The quality of life progressively decreases and patients usually die within 3-5 years after diagnosis. The previous difficulties in an effective therapy indicate our incomplete understanding of the pathogenesis of idiopathic pulmonary fibrosis. The only available treatment is lung transplantation and a new drug - pirfenidone, which may represent a potentially important advance in IPF therapy $(11-14,17)$.

One of the histopathological features of IPF is the alteration of the alveolar epithelium. It has been proven that hyperplastic type 2 pneumocytes play a role in the cycle of continued epithelial cell injury and the ineffective re-epithelialization in association with myofibroblast activation. Although significant advances have been made in understanding reasons for this abnormal process, the specific cellular and molecular mechanisms that contribute to incorrect epithelial repair and the resulting disease progression, remain unclear $(23,24)$. Hope for IPF patients may arise from novel and more accurately targeted strategies. Reactivation of signaling pathways, essential for lung development, is suspected to play a major role in the pathogenesis of IPF and may be a useful target for disease treatment. Lung development is dependent upon precise temporal and spatial control of cell proliferation, migration and differentiation processes that are mediated by diverse interactions between various cell types. Numerous signaling and transcriptional pathways, including e.g. sonic hedgehog (Shh), Wnt, bone morphogenetic protein 4 (Bmp4), vascular endothelial growth factors (Vegfs), transforming growth factor (TGF $\beta$ ), fibroblast growth factors (Fgfs), and Notch have already been implicated not only in lung morphogenesis (105, 112-117). Their role is constantly investigated in animal models, as well as human diseases and reactivation of developmental programs has been shown in COPD or PAH (9-10). The possibility, that some of these pathways are key players in the re-programming of alveolar epithelial cells to restore adult lung structure and function after injury, validates them to be important factors in the pathogenesis and treatment of pulmonary fibrosis. 
In our study, we were particularly interested in developmental pathways which may play a role in alveolar epithelial repair in IPF patients. We performed microarray experiments on microdisected septae and whole lung homogenates isolated from IPF lungs, compared to samples from healthy organ donors. As we focused our research on pathogenesis of IPF, we concentrated our effort on pathways characterized by microarray experiments performed on septae from "normal" appearing areas (which was assumed to represent an early stage of disease). Our results suggested that TGF $\beta$ and Wnt networks and the Notch signaling pathway, which were mentioned above, were differentially regulated in those samples.

TGF $\beta$ pathway elements are known to be expressed at high levels during normal mouse lung development. The lungs of the mice with targeted disruption of the TGF 22 gene did not show any abnormalities with regard to lung structure, but the animals died around birth because of respiratory failure. On the contrary, $T G F \beta 3$ null mutant mice had a specific neonatal lethal lung phenotype characterized by developmental delay, with alveolar hypoplasia, reduced expression of surfactant protein $\mathrm{C}$ and missing alveolar septal formation (118). It is well known that TGF $\beta$ is secreted by epithelial cells, macrophages, endothelial cells, and fibroblasts (108). The impact of the TGF $\beta$ pathway on IPF is undeniable $(11,119)$. As mentioned previously, a novel drug (pirfenidone), which has shown some efficacy in clinical trials and which is now authorized in the EU, has been shown to regulate the activity of this cytokine $(120,121)$. TGF $\beta$ can drive EMT, a process where epithelial cells undergo transition to a mesenchymal phenotype, giving a rise to fibroblasts and myofibroblasts. The occurrence of TGF $\beta 1$-induced EMT has been clearly demonstrated in AECs from both human and rat origin $(122,123)$. TGF $\beta$ is also known to induce intracellular matrix (ECM) production, to inhibit alveolar epithelial proliferation and to promote epithelial apoptosis $(124,125)$. Sime et al. show that TGF- $\beta 1$ overexpression in vivo, using adenoviral gene transfer, induces progressive pulmonary fibrosis in rats. In addition, the inflammatory response has not been observed in the lungs, but presence of fibroblastic foci was confirmed (126).

Another pathway which plays a major role in lung development and adult tissue homeostasis is the Wnt/ $\beta$-catenin network (127). Epithelial cell-specific expression of constitutively active $\beta$-catenin leads to epithelial cell dysplasia and ectopic differentiation of alveolar epithelial type II cells in the conducting airways during 
embryonic development. Enhanced activity of $\beta$-catenin also caused pulmonary tumors and air space enlargement in a subset of adult mice (128). In contrast, lung epithelial cell-specific deletion of $\beta$-catenin results in blocked alveolar epithelial cell differentiation, resulting in a lung structure composed primarily of conducting airways, thus demonstrating a critical requirement of $\beta$-catenin for regular formation of alveoli (129). In IPF, the Wnt/ $\beta$-catenin developmental network is one of the core signal transduction pathways involved in abnormal wound repair and fibrogenesis. WNT-1inducible signaling protein (WISP-1) is upregulated in humans with IPF and was shown to mediate pulmonary fibrosis in mice (130). Moreover, pharmacological inhibition of Wnt/beta-catenin/CREB binding protein signaling is capable of reversing experimentally induced pulmonary fibrosis. It has been shown that in response to upregulation of Wnt target genes, increased proliferation of alveolar epithelial cells occurs $(130,131)$. Activation of Wnt/ $\beta$-catenin signaling is also known to promote alveolar epithelial survival, migration, and differentiation towards an AT1-like phenotype (132). This pathway is also known to take part in the EMT process employing TGF $\beta /$ SMAD3 signaling $(133,134)$.

Our results obtained from the microarray analysis indicated an involvement of the Notch signaling pathway in IPF with a potential impact on the alveolar epithelium. The Notch pathway is well known to either promote or to repress proliferation, cell death, maintain stem cell phenotype and differentiation during embryonic and adult development. Notch is perfectly suited to precisely regulate cell-cell communication in the lung $(5-7,135)$. Because of these features the Notch pathway may turn out to be centrally involved in the pathogenesis of IPF and may have a great impact on alveolar epithelial re-epithelialization. Concerning pulmonary fibrosis the Notch signaling pathway has been found to be implicated in the EMT process via TGF $\beta /$ SMAD3 signaling $(93,136-137)$. Interestingly up to now, there is neither data on the Notch signaling pathway element expression in IPF nor on the influence of Notch activation on alveolar epithelial proliferation, differentiation or survival. 


\subsection{Reactivation of the Notch signaling pathway in lung fibrosis and other diseases}

The rationale for examining the Notch pathway in lung fibrosis does not exclusively stem from the knowledge of the influence of Notch on the regenerative response to injury in adult tissue (129-141) but also from a growing number of studies showing that Notch signaling may play a significant role in the process of fibrosis in organs such as kidney, skin and heart $(95,98,142)$. In addition, reactivation of the Notch developmental pathway was demonstrated in many other chronic lung diseases like chronic obstructive pulmonary disease (COPD) and pulmonary arterial hypertension $(\mathrm{PAH})(9,10)$. The evidence of the Notch axis involvement in various pathologies directs us to further investigate the possible role of the Notch pathway in pulmonary fibrosis.

Prior to the determination of the potential function the expression of Notch signaling pathway elements was examined. The NOTCH1 receptor and DLL1 ligand gene expression were only slightly upregulated in IPF lungs. Western blot analysis of IPF samples revealed upregulation of the NOTCH1 receptor and DLL1 ligand but of no other Notch receptor or ligand. Also upregulation of the Notch downstream target HES1 was confirmed in IPF and proved activated Notch signaling. Elevated expression of NOTCH1 and DLL1 was also observed in the animal model of bleomycin-induced lung fibrosis. NICD1 receptor was found to be upregulated from day 7 to day 21 and DLL1 ligand expression was significantly increased at day 21 and 28 post bleomycin application.

Such activation of the Notch signaling pathway has also been observed in the skin and lungs of mice with HOCl-induced systemic sclerosis, as well as in the skin of SSc patients (143). Comparable results to ours were also obtained in the previously published study of tubulointerstitial fibrosis (TIF), where increased expression especially of NOTCH1 and JAGGED1 was observed in patients with TIF and in the folic acid-induced TIF model. Accordingly, upregulation of HES1 was noticed (98). Moreover, results reflecting our data were described by Ma et al. who revealed that NICD3 and Hey1 are upregulated after 5-fluorouracil induced injury of the rat tracheal epithelium (144). It is also known that Notch1 plays a major role in the control of the adaptive response of the heart to stress conditions (139) and is activated during liver 
regeneration (141), further confirming a possible involvement of the Notch pathway in pathomechasim of lung fibrosis.

In principle, the activation of Notch1 could be achieved by increased interaction with Notch ligands, which leads to proteolytic cleavage of the receptor by the $\gamma$-secretase complex. Moreover, several mechanisms were reported to regulate activation of Notch1, including the $\gamma$-secretase complex stability and activation (145), endocystosis and trafficking of the Notch1 receptor/Notch ligands or various posttranslational modifications, namely phosphorylation, ubiquitylation, hydroxylation and acetylation (83). We can hypothesize that in IPF NOTCH1 and DLL1 proteins interact with each other to activate cleavage of the Notch1 receptor, which then plays a role as a transcription factor and increases expression of target genes such as HES1. Increased Notch pathway activation may indicate a role of this network in pathogenesis and/or progression of IPF as well as it was observed in other fibrotic diseases.

\subsection{Alveolar epithelium as a target cell type for Notch signaling}

As mentioned before, a sequential alveolar epithelial injury occurs in IPF, with epithelial cell damage and an impaired wound-healing (1). It is for this reason that AECII cells are at the center of interest when studying IPF pathology. AECII have the potential to regenerate AECI cells and to repair the injured alveolar epithelium (27). They are also known to interact with fibroblasts and extracellular matrix (146-148).

In our study, we confirmed NICD1 expression predominantly in hyperplastic AECII of IPF lungs. Increased staining in cleaved NOTCH1 was previously also observed in tubular epithelial cells of human TIF (98). We observed characteristic patterns where one cell expressed NOTCH1 in cytoplasm, while the neighbour AECII cell showed localization of NICD1 in the nucleus. During the injury a similar situation was observed in NICD3 localization of rat tracheal epithelial cells. It was suggested that Notch activation plays a role in the maintenance of an undifferentiated state of epithelial cells and the promotion of proliferation of cells (144). We suggest that NICD1 may have an impact on AECII transdifferentiation in AECI. It is in line with such theory that AECII may represent a pool of progenitor cells $(27,28)$ and Notch may play a significant role in epithelial repair after injury (to be discussed further). Additionally 
our immunohistochemistry and Western blot analysis revealed a basal level of NICD1 expression in donor lung samples, indicating that activation of the Notch signaling pathway is required for lung homeostasis (Figure 5.1). Since we also observed upregulation of the DLL1 protein in IPF samples, we performed localization studies of this ligand. We confirmed that, similar to NOTCH1 expression, DLL1 localized predominantly in hyperplastic type II cells. We therefore assume that there can be two possibilities of ligand and receptor expression in the same cell. One possibility is that the Notch ligand is presented by neighbouring cells (trans interactions) and inhibitory interaction with ligand co-expressed in the same cell (cis interactions) can occur, as suggested by Cordle et al. (71). This could explain why we see activated NOTCH1 only in a part of the alveolar epithelial cells. Another explanation could be that the NOTCH receptor can be activated by the ligand in the very same cell (e.g. on the membrane of endocytosis compartments; 44, 149). Following this line of reasoning, we were also able to identify DLL1 expression in the nucleus. It was recently discovered that DLL1 can be constitutively cleaved by ADAM10 and $\gamma$-secretase like a complex and that the intracellular region of DLL1 can be partly localized in the nucleus. The DLL1intracellular domain was shown to bind to NICD1 in the nucleus hence disrupting the Notch1-RPBJk-MAM activation complex (150). We also localized expression of HES1 protein in hyperplastic AECII, although this was not an exclusive finding. HES1 expression, which, as we mentioned before, is known to be a target gene of the Notch signaling pathway, indicates the activation of this network in epithelial cells of IPF lungs. A literature search revealed that localization of HES1 in the cytoplasm has recently also been confirmed in mucus cells of bronchioles in IPF patients (151). According to more recent data, expression of Hesl can also be regulated by Sonic Hedgehog pathway (152) and histone deacetylases (HDACs) (153). The complex regulation of the HES1 gene may be the reason for the versatile expression of HES1 in IPF lungs.

Furthermore, we studied the localization of the Notch1 receptor in the bleomycin-induced animal model of pulmonary fibrosis. In line with the results obtained with human IPF samples, we confirmed expression of NICD1 in alveolar epithelial cells 14 days post bleomycin instillation. The Notch1 receptor can also be seen in other cell types, which we assume to be inflammatory cells. It is worth to remind that at day 7 after bleomycin instillation, the NICD1 protein expression was 
already significantly increased in lung homogenates. As Notch1 is known to be expressed in $\mathrm{T}$ cells of asthmatic mice, we can not exclude the possibility that the Notch pathway is also involved in the inflammatory responses observed in the bleomycin mouse model (154).

Analogical results to ours were obtained in renal tubular epithelial cells, which play a prominent role in tubulointerstitial fibrosis (98). Immunohistochemistry of cleaved Notch1 showed expression of this protein in sections obtain from kidneys of folic acid injected mice (98). In addition, Notch activation was observed to be critical for proper reconstruction of the intestinal epithelium in mice with dextran sodium sulfate (DSS)-induced colitis. Furthermore, NICD1 overexpression was demonstrated to promote corneal epithelial wound healing $(155,156)$.

Collectively, these data encourage us to speculate that an improper level of Notch activation in the lung epithelium can be implicated in failed re-epithelialization after alveolar injury. We can suggest that marked and uncontrolled activation of the Notch1 receptor in AECII may be a factor which plays an important role in the altered process of alveolar epithelium repair, damaged in pulmonary fibrosis.

\subsection{Impact of Notch signaling on proliferation and possible differentiation}

Until now, different types of cells were characterized as a stem cell/progenitor cell of the distal lung. Firstly, Kim et al. identified bronchoalveolar stem cells (BASCs), which where found in the bronchoalveolar duct junction in the adult mouse. They demonstrated that BASCs may proliferate during epithelial repair in vivo and are capable of multipotent differentiation and self renewal in culture. After bleomycin treatment a significant increase of BASCs were observed 14 days after installation, when AECI depletion becomes evident. In vitro, culture of BASCs on Matrigel shows multilineage differentiation (CCA, SP-C and aquaporin-5 markers were identified) (157-159). Secondly, Chapman et al. identified an $\alpha 4 \beta 6$-expressing epithelial cell located both in bronchoalveolar junction regions and alveoli. This cell type obviously greatly contributed to epithelial regulation after exposure to bleomycin. In cell culture or in organoid experiments, $\beta 6+$ cells also differentiated into either airway or alveolar epithelial cells (160). Thirdly, an increase of alveolar epithelial type II cell (AECII) 
population has been observed in the distal alveolar epithelium after various insults including smoking, silica installation or pneumonectomy $(161,162)$. It is possible that, in pulmonary fibrosis, BASCs and $\alpha 4 \beta 6$-expressing cells may play a role as a stem/progenitor cell for AECII. A microenvironment, in which stem cells reside, provides essential signals required for stem cell identity and for regulation of asymmetric cell division, resulting in one daughter cell retaining the stem cell phenotype and other cells undergoing differentiation (163). We may speculate that after injury of the alveolar epithelium, stem cells divide and a part of those daughter cells differentiate into AECII, which themselves can then serve as a progenitor to rebuild the AECI layer. Dynamic and magnitude of the injury can possibly influence that progenitor cell's response. Chapman et al. demonstrated that, at day 14 post bleomycin, SP-C-positive AECII largely derived from non SP-C expressing progenitor cells at the time of injury, adding evidence to the hypothesis of $\alpha 4 \beta 6$-expressing cells serving as a progenitor cell for AECII (160). We must emphasize that in case of IPF, after injury to the alveolar epithelium, the remaining AECII may begin to proliferate in order to assist BASCs in their attempt to restore critical AECII numbers. Unfortunately, this effort of re-epithelialization fails since hyperproliferaton of AECII is not accompanied by concomitant transdifferentiation of AECII into AECI cells (164). Accordingly, it has been shown that proliferation and absence of transdifferentiation of AECII is a critical step in the development of lung fibrosis $(164,165)$. It was demonstrated that balanced proliferation of AECII can play a very important role during the proper re-epithelialization process in lung fibrosis (1, 23-24); and continuous proliferation of type II cells was observed in a hyperplastic epithelium of the fibrotic lung (162). In the bleomycin-induced mouse model the increase of $\left[{ }^{3} \mathrm{H}\right]$-thymidine incorporation was shown in AECII, after epithelial injury (28). We also confirmed that cells isolated from mice at 14 days post bleomycin-challenge showed a significant increase in DNA synthesis compared to cells isolated from control saline mice. Analogical results were described in the literature where AECII were isolated from mice 14 days post bleomycin installation compared to cells isolated from mice 5 days post bleomycin installation (130). Additionally, a study by Fukumoto et al. revealed increased PCNA protein abundance in AECII isolated from mice challenged with bleomycin, suggesting increased proliferation of these cells (166). 
In our study, we focused mainly on mechanisms resulting in a hyperproliferative state of AECII in lung fibrosis. In principle, it had been suggested that progenitor AECII cells may remain quiescent, undergo symmetric rather than asymmetric division and undergo apoptosis or transdifferentiate to AECI in response to lung injury $(5,167-169)$. The process of symmetric cell division is known to be very common during wound healing and regeneration (170). Taking into consideration our previous results (upregulation of the Notch1 receptor in "hyperplastic" AECII), we believe that the Notch signaling pathway could have a major impact on these processes in a fibrotic lung. Notch is known to be an important molecule in specifying cell fate (171). It plays a central role in asymmetrical division of stem cells (172), and cells that have a higher level of Notch activation continue to divide while those with lower levels begin to differentiate (173). Studies in the field of lung development revealed that constitutive NICD1 expression in the distal lung epithelium prevents the differentiation of alveolar epithelial cells (105). In these mice, the normal alveolar structure was lost. Instead enlarged cysts formed by cells lacking alveolar epithelial markers, but expressing molecules characteristic for proximal airway epithelium, were observed. On the other hand, other studies revealed that inhibition of the Notch pathway in a lung epithelium does not influence the distal airway differentiation $(101,102)$. These data highlight the importance of precise Notch signaling regulation in the lung development and the putative destructive effect of malevolent NOTCH1 activation.

To confirm our assumption that Notch plays a role in epithelial proliferation we performed a series of experiments in vitro. We were able to clearly colocalize NICD1 and Ki67 in hyperplastic AECII in fibrotic regions of IPF lungs confirming that these cells are actively proliferating. Increased DNA synthesis and upregulation of PCNA expression was noticed in MLE 12 cells following transfection of NICD1. Conversely, inhibition of the Notch signaling pathway significantly decreased $\left[{ }^{3} \mathrm{H}\right]$-thymidine incorporation, which clearly indicates lower a DNA synthesis level. Furthermore, after knock down of the Notch processing enzyme, POFUT1 in MLE 12 cells we could not observe any colocalization of the Notch1 receptor and the Ki67 proliferation marker. We can speculate that when Notch activation is insufficient it can lead to a lack of epithelial cell proliferation and afterwards improper repair after injury, which can be observed e.g. in diffuse alveolar damage (Figure 5.1.). Moreover, Xing et al. confirmed 
in an experimental model of naphthalene airway injury that activity of Notch1 is required for normal repair of the proximal airway epithelium (189).

To validate results obtained with MLE 12 cells we investigated primary AECII cells isolated from bleomycin-treated mice. Treatment with the $\gamma$-secretase inhibitor, DAPT, resulted in a significant reduction of DNA synthesis in mouse primary AECII cells, confirming the data obtained with MLE 12 cells. Taken together, our data indicate that Notch signaling may well play a central role in injury-driven hyperproliferation of AECII in fibrotic lung disease. In relation to those observations made in the lung, Notch was previously identified as an activator of cell proliferation in kidney fibrosis (98). Recently, it was demonstrated that overexpression of NICD1 in the mouse distal lung epithelium leads to hyperplasia and proliferation of cells in the alveolar space (174). Additionally, the Notch signaling pathway is also known to have influence on proliferation processes in other epithelial cells such as the human corneal epithelium (175) and retinal pigment epithelium (93).

As mentioned above AECII are also proven to transdifferentiate into AECI in vitro. Konishi et al. documented decreased expression of the AECI marker in IPF lungs. This implicates potential loss of type I alveolar epithelial cells and lack or improper differentiation of ACEII into AECI in this disease (164). It is known that active Notch signaling can increase epithelial cell proliferation and decreases differentiation in human corneal epithelial cells (175). Moreover, as mentioned before, it has been suggested that Notch may play a role in keeping epithelial cells in an undifferentiated state and promoting proliferation of rat trachea epithelial cells (144). It seems that the balance between proliferation and differentiation of AECII can be crucial for proper re-epithelialization in the alveolus and may contribute to the pathogenesis of pulmonary fibrosis.

\subsection{Downstream signaling of Notch responsible for enhanced proliferation}

Since the Notch pathway appears to be an important player regulating alveolar epithelial homeostasis, we were interested in the identification of pathways playing a role in the Notch-dependent increase in epithelial proliferation. The results of our mRNA microarray experiments on MLE 12 cells suggested that one of 
the signaling pathways which are differentially regulated after NICD1 overerexpression is the mitogen-activated protein kinase (MAPK) pathway. It is known that activated MAPKs participate in the control of epithelial cell proliferation and apoptosis and are activated by various stimuli $(178,179)$. Moreover mRNA expression of MAPK signaling cascade was also altered in microdisected septae from "fibrotic" areas of IPF lungs. Yoshida et al., showed differentially regulated expression of activated MAPKs in lung homogenates from patients with IPF (180). It has previously been demonstrated that a reduction activated Erk1/2 in alveolar epithelial cells was accompanied by a progression of fibrosis (180). It was suggested that dampened activation of Erk1/2 may be associated with progression of epithelial cell damage, whereas phosphorylated, activated Erk1/2 may play a protective role in AECII apoptosis (180). Our investigation did not reveal altered phosphorylation of Erk1/2 in MLE 12 cells in response to NICD1 overexpression suggesting that Erk1/2 is not a target of activated the Notch signaling pathway. Additionally, we investigated phosphorylation of Erk5 which is implicated e.g. in cellular survival and proliferation (181). We found that NICD1 overexpression in MLE 12 cells induced phosphorylation of Erk5. Reddy and colleagues reported expression of Erk5 in epithelial cell lines derived from proximal (HBE-1) and distal (Clara-like H441), as well as in the alveolar epithelial type II like cell line, A549 (182). To this day, expression and post-translation modification of Erk5 has neither been analyzed in human IPF nor in the bleomycin model of pulmonary fibrosis. Despite this, Erk5 was suggested to play a role in the pathogenesis and progression of lung fibrosis induced by asbestos (176). Scapoli et al. showed that Src-dependent Erk5 phoshorylation is required for mouse lung epithelial cell (C10) proliferation induced by asbestos (176). Our data and results reported by other groups allow us to speculate that Erk5 may be the downstream effector of Notch1 mediated epithelial proliferation.

\subsection{Impact of Notch activation on alveolar epithelium cell death}

Studies undertaken by Allen et al. revealed that in mice overexpressing NICD1 in the distal epithelium, the AECII undergo intensive proliferation which is followed by increased apoptosis (174). It is already known that uncontrolled proliferation can be associated with a high level of apoptosis (100). Proliferation and apoptosis of 
epithelium cells was also reported in IPF patients by Qunn et al. (4) and Korfei et al. (2). DNA damage and apoptosis in lung epithelial cells have also been reported in acute lung injury (184) and diffuse alveolar damage (185), as well as in IPF $(3,186)$. Moreover, the telomerase activity seems to be diminished in IPF, resulting in premature telomere shortening. According to previously published studies, telomerase expression is generally restricted to cells with the capacity to undergo proliferation and may also be an attribute of AECII $(187,188)$. Encouraged by this evidence, we investigated whether Notch signaling is involved in the pro-apoptotic process and could be responsible for the cell death of lung epithelial cells in vitro. However, we demonstrated that activation of NICD1 did not influence apoptosis by altering the level of cleaved caspase 3 or LDH release with and without cell death inducer. We also were not able to observe changes in cell death after the Notch pathway was inhibited. We understand that this observation can be explained by our experimental settings, mainly because we performed transient NICD1 overexpression and transient Notch inhibition. The duration of our in vitro experiments may not have been sufficiently long to reflect in vivo studies performed by Allen et al., where overexpression of NICD1 in AECII induced intensive proliferation followed by apoptosis of alveolar epithelial cells (174). We also have to remember that our survival studies have been performed employing an immortalized cell line, which may not sufficiently mimic the alveolar epithelium in vivo. However, similar results to ours were reported by investigators studying kidney fibrosis, documenting no influence of the Notch signaling pathway on epithelial apoptosis (98).

\subsection{Conclusions and future directions}

Idiopathic pulmonary fibrosis (IPF) is a chronic and progressive, fibrotic lung disease (11). The presently proposed pathogenic mechanism in IPF proposes occurrence of a sequential alveolar injury, which leads to the epithelial cell damage. Under normal conditions, the repair process ensures proper re-epithelialization and this mechanism seems to be impaired in IPF (1). For this reason we focused our effort on alveolar epithelial cells, which are assumed to play a main role in distal alveolar repair in pulmonary fibrosis. 


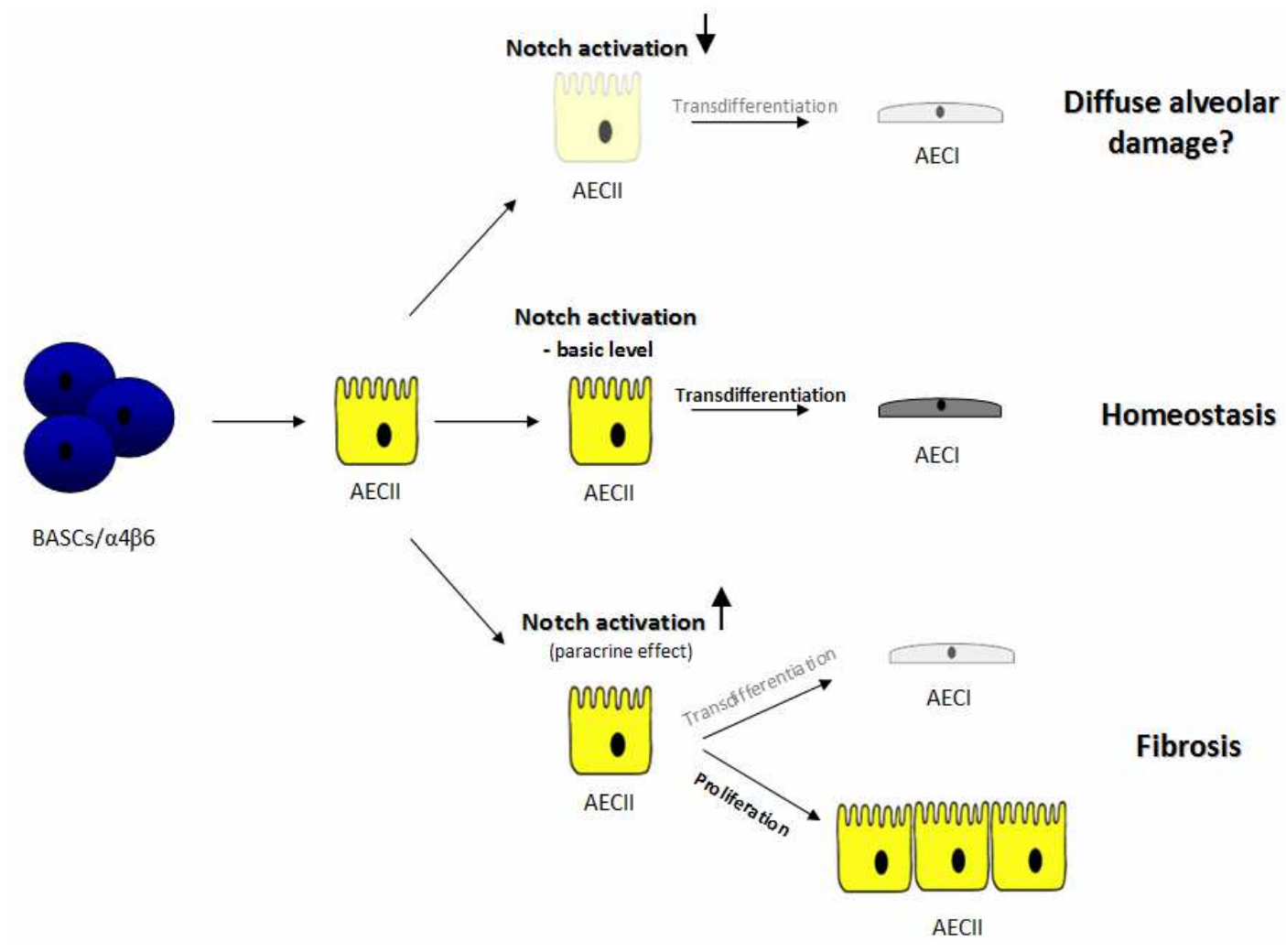

Figure 5.1. Differential regulation of Notch pathway activation may have a diverse impact on AECII proliferation and transdifferentiation into AECI.

In this investigation, we hypothesized that expression of Notch signaling pathway elements and Notch activation can be a factor playing an important role in proliferation and regeneration of the alveolar epithelium in IPF. We demonstrated the activation of the Notch signaling pathway in lungs of IPF patients and in mice the bleomycin model of pulmonary fibrosis. Moreover, our results provide evidence that differentially regulated elements of the Notch pathway are restricted mainly to alveolar epithelial cells in the injured lung. Furthermore we observed characteristic patterns where subpopulations of AECII cells expressed Notch1 in cytoplasm and neighboured AECII cells showed localization of Notch1 in the nucleus. In addition, we observed that Notch plays a major role in epithelial cell proliferation in vitro. It can be suggested that Notch activation plays a role in maintaining an undifferentiated state and promotes proliferation among the AECII cell population. We have also found that NICD1 overexpression in MLE 12 cells induced phosphorylation of Erk5 and this allows us to speculate that Erk5 may be a downstream effector of Notch1 activation. Furthermore, influence of the Notch signaling pathway on epithelial apoptosis was not observed. 
To further investigate the impact of the Notch signaling pathway on the mechanism preventing differentiation of AECII to AECI in vitro and in vivo analysis is needed. Moreover, since isolated primary cells do not reflect complex interactions in intact lungs, it would be beneficial to investigate proliferation and apoptosis of alveolar epithelial cells in mice lacking Notch1 or transgenic animals with Notch1 overexpression. It would also be also beneficial to use transgenic mice with inhibition or/and activation of the Notch signaling pathway in AECII cells to test the Notch effect on the fibrosis process after bleomycin installation. This experiment would answer the question whether the Notch pathway is a reasonable target for a therapy of IPF. As it is known, available treatment strategies are still very limited. Kavian et al. already showed that the inhibition of the Notch pathway can prevent the fibrotic process and become a useful treatment of systemic sclerosis in the future (143). In addition, since Erk5 is implicated in the control of cell proliferation and survival, it is reasonable to test whether ablation of Erk5 in NICD1-overexpressing cells impacts the proliferation rate. Additionally, future investigation could answer the question whether Notch activation correlates with Wnt or TGF $\beta$ pathways, which are well known to play a role in pulmonary fibrosis.

In conclusion, our results revealed that the Notch pathway is highly activated in AECII in pulmonary fibrosis and has an influence on epithelial cell proliferation. AECII serves as a progenitor cell and after injury, AECII seems to undergo symmetric cell division to replenish their reduced population which may not be accompanied by transdifferentiation into AECI. Together, our findings suggest that improper activation of Notch signaling could be the reason for failed re-epithelialization, during repair of the damaged lung in IPF (Figure 5.1). 


\section{References}

1. Meltzer E. B., Noble P.W. (2008) Orphanet Journal of Rare Diseases 3:8

2. Korfei M., Ruppert C., Mahavadi P., Henneke I., Markart P., Koch M., Lang G., Fink L., Bohle R.M., Seeger W., Weaver T.E., Guenther A. (2008) Am J Respir Crit Care Med. 15;178(8):838-46

3. Kuwano K., Kunitake R., Kawasaki M., Nomoto Y., Hagimoto N., Nakanishi Y., Hara N. (1996) Am J Respir Crit Care Med. 154:477-83

4. Qunn L., Takemura T., Ikushima S., Ando T., Yanagawa T., Akiyama O., Oritsu M., Tanaka N., Kuroki T. (2002) Virchows Arch 441:271-278

5. Artavanis-Tsakonas S., Rand MD, Lake R.J. (1999) Science 30;284(5415):770-6

6. Lai E.C. (2004) Development 131(5):965-73

7. Le Borgne R., Bardin A., Schweisguth F. (2005) Development 132(8):1751-62

8. Roca C., Adams R.H. (2007) Genes Dev. Oct 15;21(20):2511-24

9. Tilley A.E., Harvey B., Heguy A., Hackett N.R., Wang R., O’Connor T.P., Crystal R.G. (2009) Am J Respir Crit Care Med Vol 179. pp 457-466

10. Li X., Zhang X., Leathers R., Makino.A., Huang C., Parsa A., Macias J., Yuan J., Jamieson S.W., Thistlethwaite P.A. (2009) Nat Med. 15(11):1289-97

11. Coward W. R., Saini G., Jenkins G. (2010) Ther Adv Respir Dis 4(6) 367-388

12. Katzenstein A.L., Myers J.L. (1998) Am J Respir Crit Care Med 157(4 Pt):13011315

13. International consensus statement. American Thoracic Society (ATS) and the European Respiratory Society (ERS). (2000) Am J Respir Crit Care Med 161 (2 Pt 1):646-664

14. Gribbin J., Hubbard R.B., Le Jeune I., Smith C.J., West J., Tata L.J. (2006) Thorax 61(11):980-985

15. Kim D.S., Collard H.R., King T.E. Jr (2006) Proc Am Thorac Soc 3(4):285-292

16. Raghu G., Freudenberger T.D., Yang S., Curtis J.R., Spada C., Hayes J., Sillery J.K., Pope C.E., Pellegrini C.A. (2006) Eur Respir J, 27(1):136-142. 2:646-664 
17. Noble PW, Albera C, Bradford WZ, Costabel U, Glassberg MK, Kardatzke D, King TE Jr, Lancaster L, Sahn SA, Szwarcberg J, Valeyre D, du Bois RM; CAPACITY Study Group. (2011) Lancet May 21;377(9779):1760-9

18. Hospenthal M. A. MD (2006) Respiratory Care Vol 51 No 4

19. Selman M., King T.E., Pardo A. (2010) Intern Med 134:136-151

20. Enomoto N., Suda T., Kato M., Kaida Y., Nakamura Y., Imokawa S., Ida M., Chida K. (2006) Chest 130,22-29

21. White E. S., Lazar M. H., Thannickal V. J. (2003) J Pathol. 201(3): 343-354

22. King Y. E. Jr, Pardo A., Selman M. (2011) Lancet 378:1949-61

23. Gross T, M.D., Unninghake G. W. H, M.D. (2001) $N$ Engl J Med. Vol. 345, No. 7

24. Selman M., Pardo A. (2002) Respiratory Research 3:3.

25. Hancock A., Armstrong L., Gama R., Millar A. (1998) Am J Respir Cell Mol Biol $18: 60-5$

26. Whitsett J.A, Wert S.E, Weaver T.E (2010) Annu Rev Med. 61:105-19

27. Fehrenbach H. (2001) Respir Res 2:33-46

28. Adamson I.Y., Bowden D. H. (1974) Lab Invest 30:35-42

29. Selman M., Pardo A. (2006) Proc Am Thorac Soc Vol 3. pp 364-372

30. Matalon S., O'Brodovich H. (1999) Annu Rev Physiol. 61:627-61

31. Uhal B.D., Joshi I., Hughes W.F., Ramos C., Pardo A., Selman M.(1998) Am J Physiol Lung Cell Mol Physiol 275:L1192-9

32. Moeller A., Ask K., Warburton D., Gauldie J., Kolb M. (2008) Int J Biochem Cell Biol. 40(3): 362-382

33. Adamson I.Y. (1976) Environ Health Perspect 16:119-125

34. Claussen C.A., Long E.C. (1999) Chem Rev 99 (9):2797-2816

35. Chaudhary N.I., Schnapp A., Park J.E. (2006) Am J Respir Crit Care Med $1 ; 173(7): 76976$ 
36. Moore B.B., Hogaboam C.M. (2008) Am J Physiol Lung Cell Mol Physiol 294:L152-L160

37. Kass D., Stone Bridges R., Borczuk A. and Greenberg S. (2007) Am J Respir Cell Mol Biol Vol 37. pp 193-201

38. Garg V., Muth A.N,. Ransom J.F., Schluterman M.K., Barnes R., King I.N., Grossfeld P.D., Srivastava D. (2005) Nature 8;437(7056):270-4

39. Gridley T. (2003) Hum Mol Genet. 1;12 Spec No 1:R9-13

40. Louvi A., Arboleda-Velasquez J.F., Artavanis-Tsakonas S. (2006) Dev. Neurosci. $28(1-2): 5-12$

41. Weng A.P., Nam Y., Wolfe M.S., Pear W.S., Griffin J.D., Blacklow S.C., Aster J.C. (2003) Mol Cell Biol. 23(2):655-64

42. van Es J.H., van Gijn M.E., Riccio O., van den Born M., Vooijs M., Begthel H., Cozijnsen M., Robine S., Winton D.J., Radtke F., Clevers H. (2005) Nature 16;435(7044):959-63

43. Schroeter E.H., Kisslinger J.A., Kopan R. (1998) Nature 28;393 (6683):382-6

44. Tien A., Rajan A. and Bellen H. J. (2009) J. Cell Biol. Vol. 184 No. 5 621-629

45. Fiúza U. M., Arias A. M. (2007) Journal of Endocrinology 194, 459-474

46. Gordon W.R., Vardar-Ulu D., Histen G., Sanchez-Irizarry C., Aster J.C., Blacklow S.C. (2007) Nat Struct Mol Biol. 14(4):295-300

47. Fleming R.J. (1998) Semin Cell Dev Biol.9(6):599-607

48. Lubman O.Y., Korolev S.V., Kopan R. (2004) Mol Cell. 12;13 (5):619-26

49. Lissemore J.L., Starmer W.T. (1999) Mol Phylogenet Evol. 11 (2):308-19

50. Rebay I., Fleming R.J., Fehon R.G., Cherbas L., Cherbas P., Artavanis-Tsakonas S. (1991) Cell 15;67(4):687-99

51. Jacobsen T.L., Brennan K., Arias A.M., Muskavitch M.A. (1998) Development 125(22):4531-40

52. Hu Q.D., Ang B.T., Karsak M., Hu W.P., Cui X.Y., Duka T., Takeda Y., Chia W., Sankar N., Ng Y.K., Ling E.A., Maciag T., Small D., Trifonova R., Kopan R., 
Okano H., Nakafuku M., Chiba S., Hirai H., Aster J.C., Schachner M., Pallen C.J., Watanabe K., Xiao Z.C. (2003) Cell 17;115 (2):163-75

53. Fischer, A., Gessler, M. (2007) Nucleic Acids Res. 35, 4583-4596.,

54. Kageyama R., Ohtsuka, T. (1999) Cell Res. 9, 179-188

55. Lamar E., Deblandre G., Wettstein D., Gawantka V., Pollet N., Niehrs C., Kintner C. (2001) Genes Dev. 15, 1885-1899

56. Izon D.J., Aster J.C., He Y., Weng A., Karnell F.G., Patriub V., Xu L., Bakkour S., Rodriguez C., Allman D. and Pear W.S. (2002) Immunity 16, 231-243

57. Satoh Y., Matsumura I., Tanaka H., Ezoe S., Sugahara H., Mizuki M., Shibayama H., Ishiko E., Ishiko J., Nakajima K. and Kanakura Y. (2004) J. Biol. Chem. 279, 24986-24993

58. Palomero T., Lim W.K., Odom D.T., Sulis M.L., Real P.J., Margolin A., Barnes K.C., O'Neil J., Neuberg D., Weng A.P., Aster J.C., Sigaux F., Soulier J., Look A.T., Young R.A., Califano A., Ferrando A.A. (2006) Proc. Natl. Acad. Sci. USA 103, $18261-18266$

59. Ronchini C., Capobianco A. J. (2001) Mol. Cell. Biol. 21, 5925-5934

60. Rangarajan A., Talora C., Okuyama R., Nicolas M., Mammucari C., Oh H., Aster J.C., Krishna S., Metzger D., Chambon P., Miele L., Aguet M., Radtke F., Dotto G.P. (2001) EMBO J. 20, 3427-3436

61. Oswald F., Liptay S., Adler G., Schmid R.M. (1998) Mol. Cell. Biol. 18, 2077-2088

62. Deftos M.L., Huang E., Ojala E.W., Forbush K.A., Bevan M.J. (2000) Immunity $13,73-84$

63. Weng A.P., Millholland J.M., Yashiro-Ohtani Y., Arcangeli M.L., Lau A., Wai C., Del Bianco C., Rodriguez C.G., Sai H., Tobias J., Li Y., Wolfe M.S., Shachaf C., Felsher D., Blacklow S.C., Pear W.S., Aster J.C. (2006) Genes Dev. 20, 2096-2109

64. Deftos M.L., He Y.W., Ojala E.W. and Bevan, M.J. (1998) Immunity 9, 777-786

65. Ordentlich P., Lin A., Shen C.P., Blaumueller C., Matsuno K., Artavanis-Tsakonas S., Kadesch T. (1998) Mol. Cell. Biol. 199818, 2230-2239 
66. Axelrod J.D., Matsuno K., Artavanis-Tsakonas S., Perrimon N. (1996) Science 29;271(5257):1826-32

67. Ramain P., Khechumian K., Seugnet L., Arbogast N., Ackermann C., Heitzler P. (2001) Curr Biol. Nov 13;11(22):1729-38

68. Bray S., Furriols M. (2001) Current Biology 11:R217-R221

69. Fehon R.G., Kooh P.J., Rebay I., Regan C.L., Xu T., Muskavitch M.A., ArtavanisTsakonas S. (1990) Cell 4;61(3):523-34

70. de Celis J.F., Bray S.J. (2000) Development 127(6):1291-302

71. Cordle J., Johnson S., Tay J.Z., Roversi P., Wilkin M.B., de Madrid B.H., Shimizu H., Jensen S., Whiteman P., Jin B., Redfield C., Baron M., Lea S.M., Handford P.A. (2008) Nat Struct Mol Biol. 15(8):849-57

72. Raya A., Kawakami Y., Rodríguez-Esteban C., Ibañes M., Rasskin-Gutman D., Rodríguez-León J., Büscher D., Feijó J.A., Izpisúa Belmonte J.C. (2004) Nature $8 ; 427(6970): 121-8$

73. Strooper B., Annaert W., Cupers P., Saftig P., Craessaerts K., Mumm J.S., Schroeter E.H., Schrijvers V., Wolfe M.S., Ray W.J., Goate A., Kopan R. (1999) Nature 8;398(6727):518-22

74. Struhl and Greenwald, (1999) Nature 8;398(6727):522-5

75. Okochi M., Steiner H., Fukumori A., Tanii H., Tomita Tomista., Tanaka T., Iwatsubo T., Kudo T., Takeda M., Haass C. (2002) EMBO J. 15;21(20):5408-16

76. Sato T., Diehl T.S., Narayanan S., Funamoto S., Ihara Y., De Strooper B., Steiner H., Haass C., Wolfe M.S. (2007) J Biol Chem. 23;282(47):33985-93

77. Kopan R. and Ma. Xenia G. Ilagan (2009) Cell 17; 137(2): 216-233

78. Gupta-Rossi N., Six E., LeBail O., Logeat F., Chastagner P., Olry A., Israël A., Brou C. (2004) J Cell Biol. 5;166(1):73-83

79. Haapasalo A, Kovacs DM. (2011) J Alzheimers Dis. 25(1):3-28

80. Struhl G., Adachi A. (1998) Cell. 15;93(4):649-60

81. Fryer C.J., Lamar E., Turbachova I., Kintner C., Jones K.A. (2002) Genes Dev. 
$1 ; 16(11): 1397-411$

82. Wallberg A.E., Pedersen K., Lendahl U., Roeder R.G. (2002) Mol Cell Biol. 22(22):7812-9

83. Fortini M.E (2009) Developmental Cell 16(5):633-47

84. Nagai A., Thurlbeck W.M. (1991) Am Rev Respir Dis; 144:901-908

85. Demoly P., Simony-Lafontaine J., Chanez P., Pujol J.L., Lequeux N., Michel F.B., Bousquet (1994) J. Am J Respir Crit Care Med. 150:214-217

86. Khuri F.R., Lee J.S., Lippman S.M., Lee J.J., Kalapurakal S., Yu R., Ro J.Y., Morice R.C., Hong W.K., Hittelman W.N. (2001) Cancer Epidemiol Biomarkers Prev 10:311-318

87. Holgate S.T., Arshad H.S., Roberts G.C., Howarth P.H., Thurner P., Davies D.E. (2010) Clinical Science 118, 439-450

88. Jang S., Schaller M., Berlin A.A., Lukacs N.W. (2010) J Immunol. 185(10):5835-5844

89. Yuan J.X., Rubin L.J. (2005) Circulation 111, 534-538

90. Westhoff B., Colaluca I.N., D'Ario G., Donzelli M., Tosoni D., Volorio S., Pelosi G., Spaggiari L., Mazzarol G., Viale G., Pece S., Di Fiore P.P. (2009) Proc Natl Acad Sci USA. 29;106(52):22293-8

91. Konishi J., Kawaguchi K.S., Vo H., Haruki N., Gonzalez A., Carbone D.P., Dang T.P. (2007) Cancer Res 67:8051-8057

92. Sriuranpong V., Borges M. W., Ravi R. K, Arnold D.R., Nelkin B.D., Baylin S.B., Ball D.W. (2001) Cancer Res 61:3200-3205

93. Namba T., Tanaka K.I., Ito Y., Hoshino T., Matoyama M., Yamakawa N., Isohama Y., Azuma A., Mizushima T. (2010) Cell Death and Differentiation 17, 1882-1895

94. Smith G. P., Chan S. L. (2010) Curr Rheumatol Rep. 12(1): 26-33

95. Dees C., Zerr P., Tomcik M., Beyer C., Horn A., Akhmetshina A., Palumbo K., Reich N., Zwerina J., Sticherling M., Mattson M.P., Distler O., Schett G., Distler J.H. (2011) Arthritis Rheum. 63(5):1396-404 
96. Dees C., Tomcik M., Zerr P., Akhmetshina A., Horn A., Palumbo K., Beyer C., Zwerina J., Distler O., Schett G., Distler J.H. (2011) Ann Rheum Dis. 70(7):1304-10

97. Nath K.A. (1992) Am J Kidney Dis. 20(1):1-17

98. Bielesz B., Sirin Y., Si H., Niranjan T., Gruenwald A., Ahn S., Kato H., Pullman J., Gessler M., Haase V.H., Susztak K. (2010) The Journal of Clinical Investigation 120(11):4040-54

99. Sharma S, Sirin Y, Susztak K. (2011) Curr Opin Nephrol Hypertens. Jan;20(1):5661

100 Yamakawa T, Ayukawa T, Matsuno K. (2012) Adv Exp Med Biol. 727:37-46

101. Tsao P.N., Vasconcelos M., Izvolsky K.I., Qian J., Lu J., Cardoso W.V. (2009) Development 136(13):2297-2307.

102. Morimoto M., Liu Z., Cheng H.T., Winters N., Bader D., Kopan R. (2010) J Cell Sci. 123(Pt 2):213-224

103. Haines N., Irvine K.D. (2003) Nat Rev Mol Cell Biol 4: 786-797

104. Xu K., Nieuwenhuis E., Cohen B.L., Wang W., Canty A.J., Danska J.S., Coultas L., Rossant J., Wu M.Y., Piscione T.D., Nagy A., Gossler A., Hicks G.G., Hui C.C., Henkelman R.M., Yu L.X., Sled J.G., Gridley T., Egan S.E. (2010) Am J Physiol Lung Cell Mol Physiol. 298(1): L45-L56

105. Guseh J.S., Bores S.A., Stanger B.Z., Zhou Q., Anderson W.J., Melton D.A., Rajagopal J. (2009) Development 15; 136(10): 1751-1759

106. Dang T.P., Eichenberger S., Gonzalez A., Olson S., Carbone D.P. (2003) Oncogene 22, 1988-1997

107. Kwapiszewska G, Wilhelm J, Wolff S, Laumanns I, Koenig IR, Ziegler A, Seeger W, Bohle RM, Weissmann N, Fink L. (2005) Respir Res 6:109

108. Grigorian M., Mandal L., Hakimi M., Ortiz I., Hartenstein V. (2011) Dev Biol. May 1;353 (1):105-18

109. Mittal S., Subramanyam D., Dey D., Kumar R.V., Rangarajan A. (2009) Mol Cancer. Dec 23;8:128.

110. Kondoh K., Sunadome K., Nishida E. (2007) J Biol Chem. Feb 2;282(5):3058-65 
111. Coultas D.B., Zumwalt R.E., Black W.C., Sobonya R.E. (1994) Am J Respir Crit Care Med. Oct;150(4):967-72

112. Shiratori M., Oshika E., Ung L. P., Singh G., Shinozuka H., Warburton D., .Michalopoulos G., Katyal S. L. (1996) Am. J. Respir. Cell Mol. Biol. 15, 328338

113. Bellusci S., Grindley J., Emoto H., Itoh N., and Hogan B. L. (1997) Development $124,4867-4878$

114. Weaver M., Dunn N. R., and Hogan B. L. (2000) Development 127, 2695-2704

115. Pepicelli C. V., Lewis P. M., and McMahon A. P. (1998) Curr. Biol. 8, 1083-1086

116. Wert S. E., Dey C. R., Blair P. A., Kimura S., and Whitsett J. A. (2002) Dev. Biol. $242,75-87$

117. Li C., Xiao J., Hormi K., Borok Z., and Minno P. (2002) Dev. Biol. 248, 8-81

118. Bartram U., Speer C.P. (2004) Chest Feb;125(2):754-65

119. Gharaee-Kermani M., Hu B., Phan S.H., Gyetko M.R. (2009) Curr Med Chem. 16(11):1400-1

120. Nakayama S., Mukae H., Sakamoto N., Kakugawa T., Yoshioka S., Soda H., Oku H., Urata Y., Kondo T., Kubota H., Nagata K., Kohno S. (2008) Life Sci. Jan $16 ; 82(3-4): 210-7$

121. Iyer S.N., Gurujeyalakshmi G., Giri S.N. (1999) J Pharmacol Exp Ther. Oct;291(1):367-73

122. Kasai H., Allen J.T., Mason R.M., Kamimura T., Zhang Z. (2005) Respir Res. Jun $9 ; 6: 56$

123. Willis B.C., Liebler J.M., Luby-Phelps K., Nicholson A.G., Crandall E.D., du Bois R.M., Borok Z. (2005) Am J Pathol. May;166 (5):1321-32

124. Bhaskaran M., Kolliputi N., Wang Y., Gou D., Chintagari N.R., Liu L. (2007) J Biol Chem. 9;282(6):3 968-76

125. Lee C.G., Kang H.R., Homer R.J., Chupp G., Elias J.A. (2006) Proc Am Thorac Soc. Jul;3(5):418-23 
126. Sime P.J, Xing Z., Graham F.L., Csaky K.G., Gauldie J. (1997) J Clin Invest. Aug $15 ; 100(4): 768-76$

127. Königshoff M., Eickelberg O. (2010) Am J Respir Cell Mol Biol. Jan;42(1):21-31

128. Mucenski M.L., Nation J.M., Thitoff A.R., Besnard V., Xu Y., Wert S.E., Harada N., Taketo M.M., Stahlman M.T., Whitsett J.A. (2005) Am J Physiol 289:L971L979.

129. Mucenski M.L., Wert S.E., Nation J.M., Loudy D.E., Huelsken J., Birchmeier W., Morrisey E.E.,Whitsett J.A. (2003) J Biol Chem 278:40231-40238.

130. Königshoff M., Kramer M., Balsara N., Wilhelm J., Amarie O.V., Jahn A., Rose F., Fink L., Seeger W., Schaefer L., Günther A., Eickelberg O. (2009) J Clin Invest; $119: 772-787$

131. Henderson W.R. Jr, Chi E.Y., Ye X., Nguyen C., Tien Y.T., Zhou B., Borok Z., Knight D.A., Kahn M. (2010) Proc Natl Acad Sci USA. Aug 10;107(32):14309-14

132. Flozak A.S., Lam A.P., Russell S., Jain M., Peled O.N., Sheppard K.A., Beri R., Mutlu G.M., Budinger G.R., Gottardi C.J. (2010) J Biol Chem. Jan 29;285 (5):3157-67

133 Zhou B., Liu Y., Kahn M., Ann D.K., Han A., Wang H., Nguyen C., Flodby P., Zhong Q., Krishnaveni M.S., Liebler J.M., Minoo P., Crandall E.D., Borok Z. (2012) J Biol Chem. Jan 12

134. Königshoff M., Balsara N., Pfaff E., Kramer M., Chrobak I., Seeger W., Eickelberg O. (2008) PLoS One. May 14;3 (5):e2142

135. Glittenberg M., Pitsouli C., Garvey C., Delidakis C., Bray S. (2006) EMBO J. 18;25 (20):4697-706

136. Liu T., Hu B., Choi Y.Y., Chung M., Ullenbruch M., Yu H., Lowe J.B., Phan S.H. (2009) Am J Pathol. May;174 (5):1745-55

137. Aoyagi-Ikeda K., Maeno T., Matsui H., Ueno M., Hara K., Aoki Y., Aoki F., Shimizu T., Doi H., Kawai-Kowase K., Iso T., Suga T., Arai M., Kurabayashi M. (2011) Am J Respir Cell Mol Biol. Jul;45(1):136-44

138. Conboy M., Conboy M.J., Smythe G.M., Rando T.A. (2003) Science 302: 15751577 
139. Croquelois A., Domenighetti A.A., Nemir M., Lepore M., Rosenblatt-Velin N., Radtke F., Pedrazzini T. (2008) J Exp Med 205: 3173-3185

140. Kobayashi T., Terada Y., Kuwana H., Tanaka H., Okado T., Kuwahara M., Tohda S., Sakano S., Sasaki S. (2008) Kidney Int 73: 1240-1250, 2008.

141. Kohler C., Bell A.W., Bowen W.C., Monga S.P., Fleig W., Michalopoulos G.K. (2004) Hepatology 39: 1056-1065

142. Russell J.L., Goetsch S.C., Gaiano N.R., Hill J.A., Olson E.N., Schneider J.W. (2011) Circ Res. Jan 7;108(1):51-9

143. Kavian N., Servettaz A., Mongaret C., Wang A., Nicco C., Chéreau C., Grange P., Vuiblet V., Birembaut P., Diebold MD, Weill B., Dupin N., Batteux F. (2010) Arthritis \& Rheumatism Vol. 62, No. 11, November, pp 3477-3487

144. Ma X.B., Jia X.S., Liu Y.L., Wang L.L., Sun S.L., Song N., Wang E.H., Li F. (2009) Cell Prolif. Feb; 42(1):15-28

145. Jorissen E., De Strooper B. (2010) Curr Top Dev Biol. 92:201-30

146. Pasternack M. Jr, Liu X., Goodman R.A., Rannels D.E. (1997) Am J Physiol 272

147. Saffiotti U. (1996) Am J Pathol; 149(5): 1423-6

148. Adamson I.Y., Hedgecock C., Bowden D.H. (1990) Am J Pathol 137(2):385-92

149. Ghosh S., Paez-Cortez J.R., Boppidi K., Vasconcelos M., Roy M., Cardoso W., Ai X., Fine A. (2011) J Biol Chem. Jun 24; 286(25):22678-87

150. Jung J., Mo J.S., Kim M.Y., Ann E.J., Yoon J.H., Park H.S. (2011) Mol Cells. Aug;32(2):161-5

151. Plantier L., Crestani B., Wert S.E., Dehoux M., Zweytick B., Guenther A., Whitsett J.A (2011) Thorax. Aug;66(8):651-7.

152. Ingram W. J., McCue K.I, Tran T.H, Hallahan A.R, Wainwright B.J (2008) Oncogene 27, 1489-1500 February

153. Sang L., Roberts J.M., Coller H.A. (2010) Trends Mol Med. January; 16(1): 17-26

154. Guo X.J., Zhou M., Ren L.P., Yang M., Huang S.G., Xu W.G. (2009) Chin Med J (Engl). Nov 5;122(21):2647-51

155. Lu H, Lu Q, Zheng Y, Li Q. (2012) Mol Vis.18:403-11. 
156. Okamoto R., Tsuchiya K., Nemoto Y., Akiyama J., Nakamura T., Kanai T., Watanabe M. (2009) Am J Physiol Gastrointest Liver Physiol. Jan;296(1):G23-35

157. Driscoll B., Kikuchi A., Lau A.N., Lee J., Reddy R., Jesudason E., Kim C.F., Warburton D. (2012) Methods Mol Biol. 879:109-22.

158. Kim C.F., Jackson E.L., Woolfenden A.E., Lawrence S., Babar I., Vogel S., Crowley D., Bronson R.T., Jacks T. (2005) Cell. Jun 17;121 (6):823-35

159. Kim C.F. (2007) Am J Physiol Lung Cell Mol Physiol. Nov;293 (5):L1092-8

160. Chapman H.A., Li X., Alexander J.P., Brumwell A., Lorizio W., Tan K., Sonnenberg A., Wei Y., Vu T.H. (2011) J Clin Invest. Jul;121 (7):2855-62

161. Lee T.S., Liu Y.J., Tang G.J., Yien H.W., Wu Y.L., Kou Y.R. (2008) Crit Care Med. Sep;36(9):2597-606.

162. Uhal B.D. (1997) Am J Physiol. Jun; 272(6 Pt 1):L1031-45

163. Yamashita Y.M., Yuan H., Cheng J., Hunt A.J. (2010) Cold Spring Harb Perspect Biol. Jan;2(1):a001313

164.. Konishi K., Gibson K.F., Lindell K.O., Richards T.J., Zhang Y., Dhir R., Bisceglia M., Gilbert S., Yousem S.A., Song J.W., Kim D.S., Kaminski N. (2009) Am J Respir Crit Care Med. Jul 15;180(2):167-75

165. Englert J.M., Hanford L.E., Kaminski N., Tobolewski J.M., Tan R.J., Fattman C.L., Ramsgaard L., Richards T.J., Loutaev I., Nawroth P.P., Kasper M., Bierhaus A., Oury T.D. (2008) Am J Pathol. Mar;172(3):583-91

166. Fukumoto J., Harada C., Kawaguchi T., Suetsugu S., Maeyama T., Inoshima I., Hamada N., Kuwano K., Nakanishi Y. (2010) Am J Physiol Lung Cell Mol Physiol. Feb;298(2):L131-8

167. Panicker, M., Rao, M.S., (2000) Stem Cells and Neurogenesis. CSH Press.

168. Huttner W.B., Kosodo Y. (2005) Curr Opin Cell Biol. Dec;17(6):648-57

169. Miele L., Osborne B. (1999) J Cell Physiol. Dec;181 (3):393-409

170. Morrison S.J., Kimble J. (2006) Nature. Jun 29;441 (7097):1068-74

171. Wang S., Barres B.A. (2000) Neuron. Aug;27 (2):197-200 
172. Wakamatsu Y., Maynard T.M., Weston J.A. (2000) Development Jul; 127(13):2811-21.

173. Wang L., Chopp M., Zhang R.L., Zhang L., Letourneau Y., Feng Y.F., Jiang A., Morris D.C., Zhang Z.G. (2009) Neuroscience. Feb 18;158(4):1356-63

174. Allen T.D, Rodriguez E.M., Jones K.D., Bishop J.M. (2011) Cancer Res. Sep 15;71(18):6010-8.

175. Ma A., Boulton M., Zhao B., Connon C., Cai J., Albon J. (2007) Invest Ophthalmol Vis Sci. Aug; 48(8):3576-85

176. Schouwey K., Aydin I.T., Radtke F., Beermann F. (2011) Oncogene. Jan 20; 30(3):313-322

177. Scapoli L., Ramos-Nino M.E., Martinelli M., Mossman B.T. (2004) Oncogene. Jan;23(3):805-13

178. Fukagawa N.K., Timblin C.R., Buder-Hoffman S., Mossman B.T (2000) Antioxid Redox Signal 2(3):379-89

179. Buckley S., Driscoll B., Barsky L., Weinberg K., Anderson K., Warburton D. (1999) Am J Physiol. Jul;277 (1 Pt 1):L159-66

180. Yoshida K., Kuwano K., Hagimoto N., Watanabe K., Matsuba T., Fujita M., Inoshima I. Hara N. (2002) J Pathol. Nov;198 (3):388-96

181. Drew B.A., Burow M.E., Beckman B.S. (2012) Biochim Biophys Acta. Jan;1825 (1):37- 48

182. Reddy S.P., Adiseshaiah P., Shapiro P., Vuong H. (2002) Am J Respir Cell Mol Biol. Jul;27(1):64-70

183. Alenzi F.Q., Br (2004) J Biomed Sci. 61(2):99-102

184. Bardales R.H., Xie S.S., Schaefer R.F., Hsu S.M. (1996) Am J Pathol. Sep;149 (3):845-52.

185. Guinee D. Jr, Fleming M., Hayashi T., Woodward M., Zhang J., Walls J., Koss M., Ferrans V., Travis W. (1996) Am J Pathol. Aug;149(2):531-8.

186. Barbas-Filho J.V., Ferreira M.A., Sesso A., Kairalla R.A., Carvalho C.R., Capelozzi V.L. (2001) J Clin Pathol. Feb;54(2):132-8. 
187. Armanios M.Y., Chen J.J., Cogan J.D., Alder J.K., Ingersoll R.G., Markin C., Lawson W.E., Xie M., Vulto I., Phillips J.A. 3rd, Lansdorp P.M., Greider C.W., Loyd J.E. (2007) . N Engl J Med 356: 1317-1326

188. Tsakiri K.D., Cronkhite J.T., Kuan P.J., Xing C., Raghu G., Weissler J.C., Rosenblatt R.L., Shay J.W., Garcia C.K. (2007) Proc Natl Acad Sci USA. May 1;104(18):7552-7.

189. Xing Y., Li A., Borok Z., Li C., Minoo P. (2012) Stem Cells. May;30(5):946-55 
Der Lebenslauf wurde aus der elektronischen Version der Arbeit entfernt.

The curriculum vitae was removed from the electronic version of the paper. 


\section{Declaration}

Hiermit erkläre ich, dass ich die vorliegende Arbeit selbständig und ohne unzulässige Hilfe oder Benutzung anderer als der angegebenen Hilfsmittel angefertigt habe. Alle Textstellen, die wörtlich oder sinngemäß aus veröffentlichten oder nichtveröffentlichten Schriften entnommen sind, und alle Angaben, die auf mündlichen Auskünften beruhen, sind als solche kenntlich gemacht. Bei den von mir durchgeführten und in der Dissertation erwähnten Untersuchungen habe ich die Grundsätze guter wissenschaftlicher Praxis, wie sie in der „Satzung der Justus-Liebig-Universität Gießen zur Sicherung guter wissenschaftlicher Praxis“ niedergelegt sind, eingehalten sowie ethische, datenschutzrechtliche und tierschutzrechtliche Grundsätze befolgt. Ich versichere, dass Dritte von mir weder unmittelbar noch mittelbar geldwerte Leistungen für Arbeiten erhalten haben, die im Zusammenhang mit dem Inhalt der vorgelegten Dissertation stehen, oder habe diese nachstehend spezifiziert. Die vorgelegte Arbeit wurde weder im Inland noch im Ausland in gleicher oder ähnlicher Form einer anderen Prüfungsbehörde zum Zweck einer Promotion oder eines anderen Prüfungsverfahrens vorgelegt. Alles aus anderen Quellen und von anderen Personen übernommene Material, das in der Arbeit verwendet wurde oder auf das direkt Bezug genommen wird, wurde als solches kenntlich gemacht. Insbesondere wurden alle Personen genannt, die direkt und indirekt an der Entstehung der vorliegenden Arbeit beteiligt waren. Mit der Überprüfung meiner Arbeit durch eine Plagiatserkennungssoftware bzw. ein internetbasiertes Softwareprogramm erkläre ich mich einverstanden.

Ort, Datum

Unterschrift 


\section{Acknowledgements}

I'd like to express my appreciation to all the following ones who have made the completion of this Dissertation possible.

My first acknowledgement goes to my principle investigator, Prof. Dr. Andreas Günther. I am extremely grateful that he has given me the opportunity to work in his group during my $\mathrm{PhD}$ thesis and for showing me that being a scientist is not only working in the lab, but also working and dealing with people. Moreover, I am very thankful for his guidance, ideas and especially his patience during the course of this work.

I want to thank Prof. Dr. Werner Seeger, for accepting me into the MBML program, where I received great training in lung biology.

I would like to express my sincere gratitude to Dr. Ingrid Henneke for her incredible help with animal experiments and Dr. Jochen Wilhelm for his tremendous work on microarray experiments. I am also very grateful to Dr. Malgorzata Wygrecka for our scientific discussions and her helpful suggestions during my study.

I also want to thank my lab colleagues that worked with me: Dr. Clemens Ruppert, Dr. Martina Korfei and Dr. Poornima Mahavadi and all students from our group for their help and support. The technicians Steffi, Silke, Leonie and Dirk are thanked for their help in everyday lab work and being of great assistance in many experiments. My sincere thanks to Sandy and Conny from whom I received great help in administrative issues.

Finally, I would like to thank my friends and family for their great support. I am especially grateful to Lukasz, his love and understanding. Finally, nothing would have been possible without my parents and my sister who had an enormous amount of faith in me. To them I dedicate this thesis. 